\title{
Effects of ankle-foot orthosis on paretic ankle dorsiflexors
}

Citation for published version (APA):

Geboers, J. F. M. (2001). Effects of ankle-foot orthosis on paretic ankle dorsiflexors. [Doctoral Thesis, Maastricht University]. Universiteit Maastricht. https://doi.org/10.26481/dis.20011109jg

Document status and date:

Published: 01/01/2001

DOI:

10.26481/dis.20011109jg

Document Version:

Publisher's PDF, also known as Version of record

\section{Please check the document version of this publication:}

- A submitted manuscript is the version of the article upon submission and before peer-review. There can be important differences between the submitted version and the official published version of record.

People interested in the research are advised to contact the author for the final version of the publication, or visit the DOI to the publisher's website.

- The final author version and the galley proof are versions of the publication after peer review.

- The final published version features the final layout of the paper including the volume, issue and page numbers.

Link to publication

\footnotetext{
General rights rights.

- You may freely distribute the URL identifying the publication in the public portal. please follow below link for the End User Agreement:

www.umlib.nl/taverne-license

Take down policy

If you believe that this document breaches copyright please contact us at:

repository@maastrichtuniversity.nl

providing details and we will investigate your claim.
}

Copyright and moral rights for the publications made accessible in the public portal are retained by the authors and/or other copyright owners and it is a condition of accessing publications that users recognise and abide by the legal requirements associated with these

- Users may download and print one copy of any publication from the public portal for the purpose of private study or research.

- You may not further distribute the material or use it for any profit-making activity or commercial gain

If the publication is distributed under the terms of Article $25 \mathrm{fa}$ of the Dutch Copyright Act, indicated by the "Taverne" license above, 


\section{Effects of ankle-foot orthosis on paretic ankle dorsiflexors}

\section{Proefschrift}

ter verkrijging van de graad van doctor aan de Universiteit Maastricht, op gezag van de Rector Magnificus

Prof. dr. A.C. Nieuwenhuijzen Kruseman volgens het besluit van het College van Decanen in het openbaar te verdedigen op vrijdag 9 november 2001 om 14.00 uur door

\section{JFM Geboers}

geboren te Tilburg op 11 december 1965 . 


\title{
Promotiecommissie
}

\section{Promotor}

prof. dr. F. Spaans

\section{Co-promotores}

\author{
dr. H.A.M. Seelen \\ dr. ir. M.R. Drost
}

\section{Beoordelingscommissie}

prof. dr. H. Kuipers (voorzitter)

prof. dr. J. Drukker

dr. I.J.M. de Groot (AMC Amsterdam)

dr. C.J. Höweler

prof. dr. H.J. Stam (Erasmus Universiteit Rotterdam)

ISBN 90-74421-11-3

(C2001 J.F.M. Geboers, Heerlen, The Netherlands

Lay out and production: Ingrid Heller \& Hein Berendsen PR.

Cover design: Pascale Mali.

All rights are reserved. No part of this publication may be reproduced or transmitted in any form or by any means, without permission in writing from the copyright owner.

Financial supports of the studies of this thesis: the Foundation 'De drie Lichten'

the Rehabilitation Foundation Limburg (SRL) the Institute for Rehabilitation Research (iRV).

Financial support by the Atrium medical center Heerlen for printing this thesis is greatfully acknowledged. 
Voor ons pap en mam. 


\section{Contents}

Chapter 1

General Introduction

Chapter 2

Paresis of ankle dorsiflexors

2.1 Incidence

2.2 Aetiology and diagnosis

2.3 Treatment and prognosis

2.4 AFO use related to muscle activity, disuse and walking

Chapter 3

Effect of immobilization on ankle dorsiflexor strength

Chapter 4

Immediate and long term effects of an ankle-foot orthosis on muscle activity during walking, a randomised study in patients with an unilateral foot drop

Chapter 5

Evaluation of effect of ankle-foot orthosis use on strength restoration of paretic dorsiflexors

Chapter 6

Effects of ankle dorsiflexor paresis and AFO use on walking test performances

Chapter 7

General conclusion and discussion

Summary

Samenvatting

Appendix

Dankwoord

Curriculum vitae 
$\mathbf{i}$ 
Chapter 1

General Introduction 
Chapter 1 
A lesion of the peroneal nerve, resulting in a paresis of the ankle dorsiflexors, is an often encountered diagnosis. The foot drop, the result of the paresis of the ankle dorsiflexors, can be corrected by the use of an ankle-foot orthosis (=AFO). An AFO is a semi-rigid orthosis, supporting the ankle in a neutral or slightly dorsiflexed position, preventing the foot from touching the ground during swing phase. In most cases, the ankle dorsiflexor paresis has a fairly good prognosis, which causes a dilemma whether or not to prescribe this orthosis. Besides the desired effect of an immediate improvement of the walking ability, the AFO may have a (long term) effect on the strength of the paretic ankle dorsiflexors. Both a negative disuse effect or a positive stimulating effect are conceivable. A disuse effect could occur if the paretic muscles become even less active due to the fact that their function is, at least partially, taken over by the orthosis, resulting in a further lessening of strength. Also, after several weeks of orthosis use, central adaptation may take place, causing a lower central neural stimulation of the muscle, thus further diminishing muscle activity. However, a positive effect for the paretic muscle could be the regaining of strength. This could be the result of an increase in the general activity level of the patient facilitated by the orthosis, and probably simultaneously increasing the activity of the paretic muscle in the total movement pattern. Assuming the negative long term effect, this dilemma is of especial relevance in patients with a paresis existing for several months because their prognosis for (partial) nerve regeneration, and thereby restoration of muscle strength, is still fairly good. In these cases, giving an orthosis to gain functional improvement on short notice, should not counteract strength recovery on the long term by inducing disuse effects in the already paretic muscles.

\section{Aim of this thesis}

The aim of this thesis is to determine the effects of six weeks of AFO use on the activity of the paretic muscles, development of strength and restoration of walking, in patients with a peripheral paresis of the ankle dorsiflexors.

Patients with a fairly recent paresis of the ankle dorsiflexors due to peripheral nerve damage or a $L 5$ radiculopathy were included in this prospective study. At the moment of inclusion of the patient, the lesion existed between six weeks and one year. The boundary of one year was made because possible disuse effects caused by AFO use could counteract strength recovery in patients who still have a chance of (partial) nerve regeneration and could thereby prevent this group from regaining unaided walking. Patients with a paresis of less than six weeks were excluded because during this period quick recovery is still possible for this group and an orthosis is normally not indicated. Patients with a paresis of the dorsiflexors of central origin were excluded to avoid any complicating effect of spasms, 
cognitive problems and severe sensory disturbances. During the follow-up time of six weeks possible disuse effects should become evident as this effect is most pronounced in the first weeks of (partial) immobilization. Central neurological adaptation, should it occur, will also be evident during this follow-up time.

Measurements used in this study consisted of surface electromyographic (EMG) registration of the activity of five lower leg muscles while the subject walked on a level treadmill. Isometric strength was determined on a dynamometer with the ankle in $0^{\circ}$ and $30^{\circ}$ plantar flexion. Finally, walking ability was assessed with the 10 metre walking test, with and without three steps, a six-minute walking test with a cognitive task, the SIP68 mobility scale and a questionnaire for subjective evaluation of the AFO.

Chapter 2 gives a short overview of the aetiology of a foot drop, the clinical symptoms, and the surgical and paramedical interventions. The possible effects of AFO use on muscle activity, central adaptation and walking ability are discussed.

In Chapter 3 the susceptibility of the ankle dorsiflexor muscles to immobilization in persons without a nerve lesion, is studied in subjects whose ankle had been immobilized in a plaster cast after an uncomplicated fracture of the lower leg. If the ankle dorsiflexors should not show loss of strength during total immobilization, a negative effect of the partial immobilization caused by AFO use will become very unlikely. Also, the reproducibility of the strength measurements in healthy adults is described and reference strength values are reported.

Chapter 4 describes the influence of orthosis use on muscle activity, as measured by surface EMG. The registered EMG activity is studied for both quantitative and qualitative changes during the step cycle. The reproducibility of the EMG measurements is determined in healthy subjects. The differences in immediate changes in EMG patterns due to AFO use between patients with a dorsiflexor paresis and healthy people are discussed. The occurrence of adaptation in muscle activity to AFO use is studied by comparing EMG measurements in patients who did use an AFO during six weeks with patients who did not.

In Chapter 5 the influence of AFO use on strength restoration is studied by comparing the recuperation of a recent paresis between patients with and without AFO use during six weeks follow-up.

Because the relation between an impairment and the subsequent disability is a main feature in rehabilitation medicine, in Chapter 6 the relation between the degree of paresis and the performance on several walking tests is studied. Also the effect of AFO use on the outcome of these tests related to different degrees of paresis is described here, to look whether a threshold can be found above which an AFO does significantly improve walking.

Finally, in Chapter 7, a general conclusion and overview of the different studies is given and some additional findings are discussed. 
Chapter 2

Paresis of ankle dorsiflexors 
Chapter 2 
This chapter briefly describes some anatomical and functional features of the ankle dorsiflexors and the consequences of a lesion of their innervation. Next, three aspects influencing recovery of strength and walking ability are described, namely the treatment of the nerve lesion, the possible effects of paramedical interventions and the use of an orthosis.

\subsection{Incidence}

The incidence and prevalence of paresis of the dorsiflexors is difficult to estimate because it often is an additional, not separately registered, diagnosis. Also, patients with a moderate paresis will, in many instances, not be referred to a clinic for further diagnosis or treatment because neither patient nor their general practitioner expect further gain. Registration in the departments of Neurology and Rehabilitation of the Atrium medical center in Heerlen, the Netherlands, revealed an incidence of approximately 1:6000 (based on a total population of 300.000), registered over a period of three years, with peroneal nerve lesion as main diagnosis. In general, the male/female ratio is 2 à $3 / 1^{1,2}$.

\subsection{Aetiology and diagnosis}

\subsubsection{Anatomy}

The common peroneal nerve originates from the sciatic nerve. It contains nerve fibres from the roots L4 through S2. In the popliteal fossa, the common peroneal nerve gives off the lateral sural cutaneous nerve, which innervates the skin over the upper half of the lateral side of the lower leg. Near the fibular head the nerve divides into the superficial and deep peroneal nerve. The superficial peroneal nerve is a mixed sensory and motor nerve. It innervates the lower part of the skin of the lateral leg and the dorsum of the foot and has a motor function for the peroneus longus and brevis muscles, which are active in foot eversion. The deep peroneal nerve is primarily a motor nerve and innervates the tibialis anterior (TA), extensor hallucis longus (EHL) and extensor digitorum longus $(E D L)$, the ankle dorsiflexors, and also the extensor digitorum brevis (EDB) and peroneus tertius (PT) muscle. Sensory disturbances are restricted to the dorsum of the first web space of the foot and are of no clinical relevance.

The anatomical position of the peroneal nerve makes it vulnerable to pressure. In most cases, the deep peroneal branch is more affected than the superficial branch, resulting predominantly in motor symptoms, i.e. paresis of the dorsiflexor muscles. In Figure 1, the position of the peroneal nerve at the fibular head is indicated and the main muscles of the lower leg, involved in ankle dorsiflexion and plantar flexion are specified. 


\section{Figure I}

\section{Muscles lower leg and position of peroneal nerve}

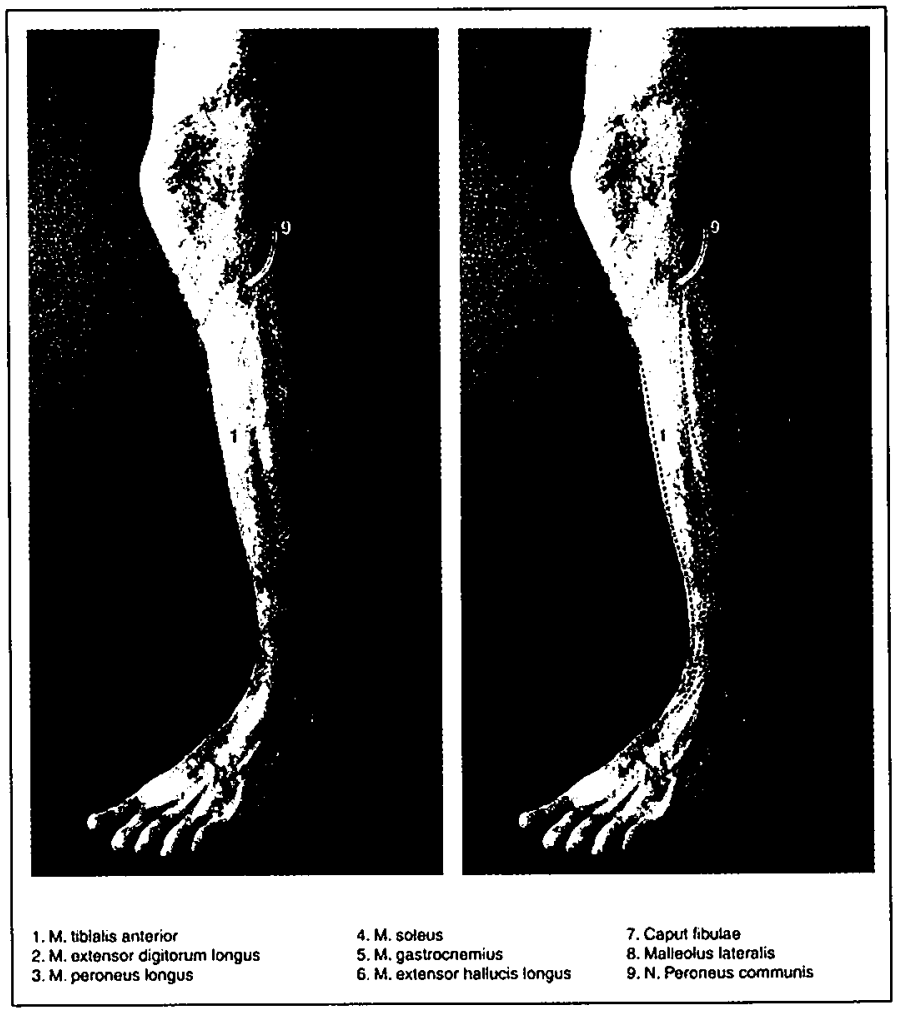

University Maastricht

Department of Anatomy.

Acute lesions are mainly associated with positioning during surgery or traumatic lesions caused by lacerations or severe stretch. Gradually developing nerve lesions are often related to sustained bed rest, leg crossing, weight loss or polyneuropathy ${ }^{3}$. Another frequent cause of ankle dorsiflexion paresis is a L5 radiculopathy caused by a protruding disc. As to frequency of occurrence, van Langenhove et al. ${ }^{2}$, in a retrospective study, classified 148 patients' peripheral paresis by EMG findings as caused mainly by an isolated peroneal nerve lesion ( $31 \%)$, a L5-radiculopathy $(20 \%)$ or a polyneuropathy $(19 \%)$.

\subsubsection{Clinical signs and symptoms}

The foot drop, caused by the paresis of the dorsiflexors, results in a typical walking pattern, the so-called cock's stride. After heel strike the foot drops to the floor instead of being slowed down by the eccentric contraction of the dorsiflexors. During swing phase, patients compensate for the loss of 


\section{Figure I}

Muscles lower leg and position of peroneal nerve

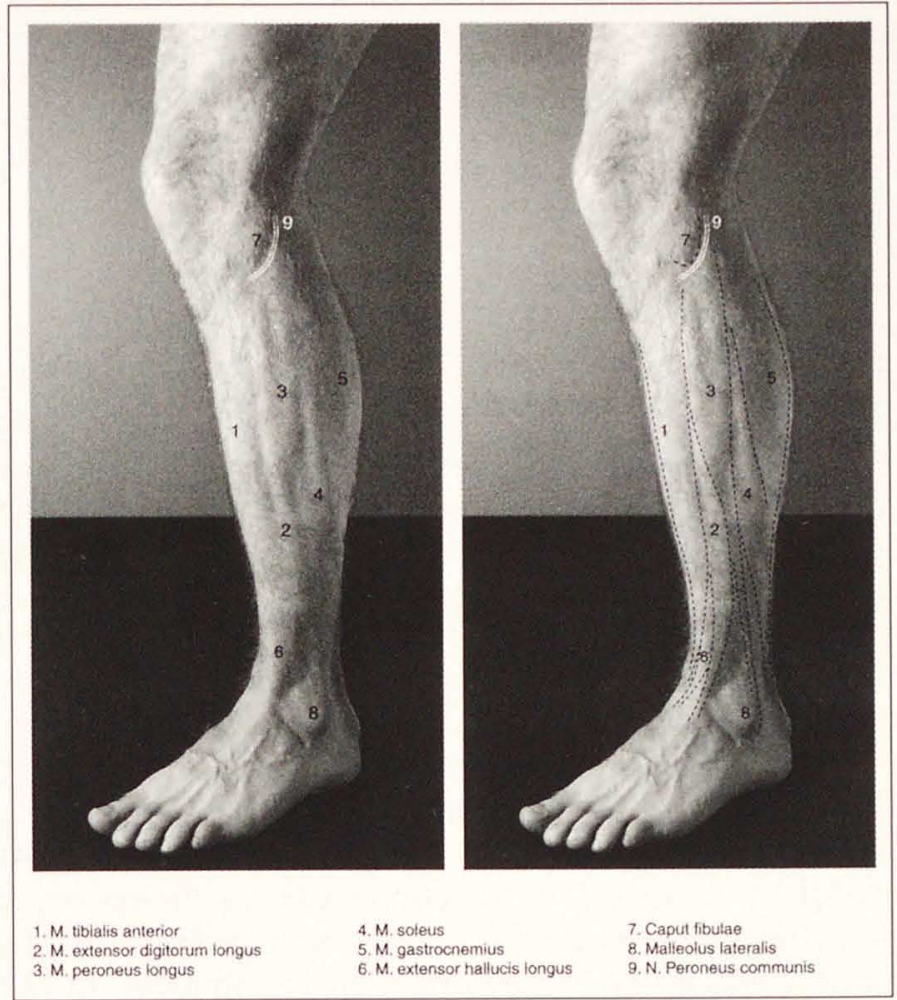

University Maastricht

Department of Anatomy.

Acute lesions are mainly associated with positioning during surgery or traumatic lesions caused by lacerations or severe stretch. Gradually developing nerve lesions are often related to sustained bed rest, leg crossing, weight loss or polyneuropathy ${ }^{3}$. Another frequent cause of ankle dorsiflexion paresis is a L5 radiculopathy caused by a protruding disc. As to frequency of occurrence, van Langenhove et al. ${ }^{2}$, in a retrospective study, classified 148 patients' peripheral paresis by EMG findings as caused mainly by an isolated peroneal nerve lesion (31\%), a L5-radiculopathy (20\%) or a polyneuropathy (19\%).

\subsubsection{Clinical signs and symptoms}

The foot drop, caused by the paresis of the dorsiflexors, results in a typical walking pattern, the so-called cock's stride. After heel strike the foot drops to the floor instead of being slowed down by the eccentric contraction of the dorsiflexors. During swing phase, patients compensate for the loss of 
ankle dorsiflexion with excessive flexion of the hip to prevent the toes from touching the ground. In case of a severe paresis this also results in a reversed gait pattern in which toe strike precedes heel strike i.e. the toes contact the floor at an earlier stage in the gait cycle than the heel. During physical examination the patient often is unable to stand on his heels with the forefeet elevated due to the paresis of the dorsiflexors. Because the superficial peroneal nerve is relatively spared, a paresis of the eversion of the foot is less common and sensory disturbances are not predominant. In case of a L5 radiculopathy the active inversion of the foot can be diminished due to involvement of the tibialis posterior muscle.

\subsubsection{Electrophysiologic evaluation}

Nerve conduction studies in case of a foot drop are performed to confirm the diagnosis and establish the exact location and severity of the nerve lesion. In case of a peripheral nerve lesion the latency time, the time necessary for the target muscle to contract after a stimulus is given, is prolonged. If there is a nerve lesion located at the side of the fibular head, nerve conduction is markedly decreased when comparing latency times between a nerve stimulus given above and below the fibular head. This information assists in setting a prognosis concerning nerve recovery. Although peroneal nerve conduction studies are mostly done with the EDB as the target muscle this is not very reliable, because, due to atrophy of this small muscle, the signal amplitude may be very low. In addition to the EDB, recordings should therefore also be done on the $T A^{4,5}$, also because the function of the TA is the main relevant issue. Katirji', found axonal loss in $55 \%$ of cases, conduction block secondary to focal demyelination in $20 \%$ and $25 \%$ mixed lesions in a population of 116 patients with common peroneal mononeuropathy. Van Langenhove et al. ${ }^{2}$ found a partial axonotmesis in $92 \%$ of 148 cases. The prognosis in case of axonal loss is less favourable compared to a conduction block 6 . In the latter, recovery is spontaneous within 6 to 8 weeks, with a maximum of up to 3 months, as long as further compression is prevented. In case of axonal loss, recovery can take more than 6 months, depending on location and extent of the lesion.

\subsection{Treatment and prognosis}

Recovery primarily depends on the (spontaneous) recuperation of nerve function, followed by the regaining of strength and the restoration of normal gait. However, the timing and amount of strength recovery varies largely, depending on severity of the nerve lesion, overall health status, age etc.. In case of a protrusion of the lumbar disc or peripheral pressure on the nerve, two treatment options, i.e., either conservative or surgical intervention, exist. 


\subsubsection{Surgical interventions}

Surgical interventions in case of a $L 5$ radiculopathy

In case of a protruding disc or another structure pressing on the nerve root, removal of pressure is the goal of an operation. Comparing of the results of surgical intervention and conservative treatment reported in literature is difficult because there is a large variability in inclusion criteria, pre-operative duration of the paresis, outcome criteria, measurements, and follow-up periods reported. Factors associated with postoperative results on strength recovery are the preoperative level of paresis 7,8 , level and extent of the lesion $3,7,9,10$, patients age ${ }^{9,11,12}$ and time interval until operation $7,9,10,11,13$. Several other authors ${ }^{12,14,15}$, however, claim no relation between duration of paresis and restoration of strength after surgery. In the only study with a long follow-up of 10 years, Weber $^{12}$ found no differences in functional prognosis (defined by pain, lumbar spine mobility, paresis, return to work) between surgical and conservative intervention in patients with lumbar disc protrusion. A gradual recovery of symptoms was seen during three to four years. In the final six years of follow up, no major changes did occur.

Surgical interventions in case of a peripheral compression

Although scarcely performed in the Netherlands, surgical release of pressure of the peroneal nerve at the location of the fibular head, is sometimes advocated to accelerate and improve nerve regeneration if no functional gain has taken place during three to four months of conservative therapy ${ }^{16,17,18}$. However, these studies do not provide a clear answer to the question for which group of patients and at which time, surgery significantly improves functional outcome in terms of strength recovery and walking ability. The commonly accepted indications for local surgery are directly after a penetrating trauma to explore the continuity of the nerve, secondly, in case of a local tumour or, thirdly, when the paresis is accompanying a compartment syndrome ${ }^{19}$.

Surgical interventions in case of persistent foot drop

Orthopaedic corrections $20,21,22$, such as tendon transfers and/or arthrodeses are sometimes advocated in case of a persisting foot drop. Different techniques are possible to replace active dorsiflexion by transfer of non-paretic muscles or to prevent foot drop by a subtalar arthrodesis. However, these surgical interventions often are not performed for a single peroneal nerve palsy and are therefore not extensively discussed here.

\subsubsection{Paramedical interventions}

Physiotherapy is often prescribed to patients with a paresis due to a nerve lesion. The goals depend on the severity and prognosis of the nerve lesion. If a paralysis exists with a poor prognosis, the main goal is prevention of secondary problems (i.e. overuse of the healthy side, injuries, contractures of the paretic limb) and learning the patient how to compensate for the loss of function. If a paresis has a reasonable or good prognosis of recovery, 
therapy will be aimed at restoring strength, training of endurance, and functional use of the leg in standing, walking or even sport activities. Whether physiotherapy also contributes to nerve regeneration is not clear. Meeteren ${ }^{23}$, in his thesis, described a quicker recovery of function in rats with a nerve lesion when they were forced to use the paretic limb ${ }^{24}$. Denervated muscle fibres can be 'adopted' by intact motor units through collateral reinnervation as can be deducted from electromyographic studies. Maybe this process of 'adopting' is enhanced by stimulating the paretic muscle to contract, thus stimulating functional recovery 25 .

\subsubsection{Orthosis use}

Whatever the cause or treatment, even patients who eventually recover are often faced with a period of several months of walking with paretic dorsiflexors. In those cases, using an orthosis, possibly temporarily, will be considered by the physician. An AFO is used to prevent the toes from touching the ground during swing phase and to enable control of the position of the foot during heel strike.

\subsection{AFO use related to muscle activity, disuse and walking}

\section{Muscle activity}

Muscle activity during the step cycle can be assessed with surface EMG. An example of the timing of muscle activity during a normal step cycle is given in Figure 2. The TA activity can be divided in two phases, the swing phase, to prevent the toes from touching the ground by a concentric contraction, and, secondly, the stance phase immediately after heel strike to control foot placing by an eccentric contraction.

In healthy volunteers an increase in muscle activity was found during the use of different types of lower leg orthoses. Cerny et al. ${ }^{25}$ reported a 3-10\% higher activity in parts of the gait cycle of the biceps femoris and soleus muscles when persons walked with a knee-ankle-foot orthosis. Tomaro \& Burdett ${ }^{26}$ described a rise in muscle activity of the TA of 3\% after heel strike in persons wearing an ankle orthosis to stabilise the ankle joint. These changes are thought to be caused by limiting free joint movement and adding extra weight to the leg. Comparable effects can of course be expected in AFO use although the weight of an AFO is only about 125 gram. A difference in muscle reaction pattern, however, might be expected in paretic muscles compared to the results of studies performed in patients with healthy muscles. Extrapolation of study results of a healthy population to subjects with a paresis is then debatable. Because orthoses are often prescribed in case of a (peripheral) paresis it is important to specifically evaluate the effect on paretic muscles. 


\section{Figure 2}

Activity pattern of the lower leg muscles during a step cycle.

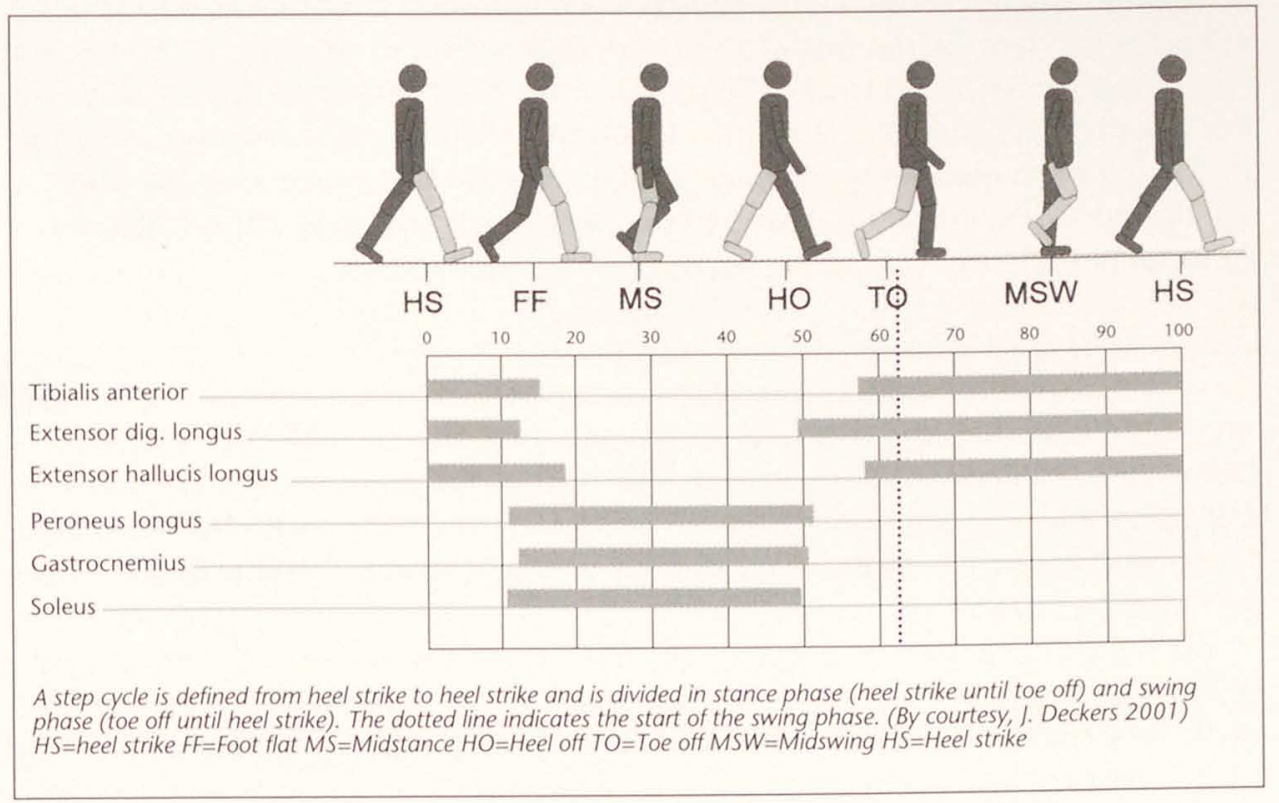

Another important factor influencing muscle activity, is the activation of the muscle by the brain. Recent literature on plasticity of the brain shows large changes in cortical representation of a limb or other parts of the body after a paresis or amputation $27,28,29,30,31,32$. If a paretic muscle would become even less active while using an orthosis this could result in a diminished central stimulation thus further reducing muscle activation. This might cause a difference in the effects of AFO use on muscle activity after a period of adaptation compared to the immediate effect caused by the altered walking pattern. However, no studies have been performed on paretic muscles, recording muscle activity and possible central adaptation effects over time regarding gait.

\section{Disuse}

Orthosis use facilitates walking and could lead to an overall higher activity level of the patient, probably stimulating the paretic muscle, or cause a further decrease of muscle activity by taking over its function, causing disuse. Disuse has proven to generate a large number of changes in the human muscles, predominantly associated with atrophy and muscle weakening ${ }^{33,34}$. The amount of decrease in strength due to disuse varies with different muscles, joint position and duration of immobilization. For the dorsiflexors, immobilization of the ankle leads to a reported strength reduction ranging from $8 \%{ }^{36}$ to $22-30 \%{ }^{37}$. 
On the other hand, more isometric muscle activity has a positive influence on maintaining strength and can counteract disuse effects in healthy muscles $37,38,39,40$. In that way, improving overall activity with an orthosis could have a positive effect on the strength of the paretic muscles.

\section{Walking performance}

Last but not least, an important question remains whether an orthosis does improve the walking ability for which it is primarily prescribed. There is a vast number of articles using gait analysis to describe the effect of a knee brace or AFO on various walking parameters. For example, the use of an AFO causes a change in the duration of stance phase events, in the magnitude of ground reaction forces, and in the locus of the centre of pressure in normal individuals with intact neuromuscular compensatory mechanisms $25,41,42,43$. Also, the effects of different types of orthoses are described by Lehmann et al. ${ }^{44,45,46,47}$ and Perry 48 in gait analysis studies to determine the optimum ankle angle for an orthosis to return step length and the timing of gait events as much to the normal reference values as possible. Some studies try to evaluate the effect of an orthosis in activities of daily living (ADL) in healthy subjects ${ }^{49}$ and patients satisfaction with the AFO both in stroke patients as in patients with peripheral nerve lesions ${ }^{50,51}$. None of them found a significant improvement in walking with an AFO as measured by the Sickness Impact Profile (category ambulation), the 10 meter walking test or questionnaires, but, on the contrary, draw attention to the large number of dissatisfied and non compliant patients. However, because these walking tests are frequently used in literature to evaluate walking ability and have been proven to be reliable in healthy subjects, we chose to use the same tests in our study. In addition, a 10 metre walking test with stairs and the six minute walking test were performed to try to be able to differentiate between walking during a simple condition, a more complex task and a duration task. 


\section{References}

1. Katirji MB, Wilbourn AJ. Common peroneal mononeuropathy: a clinical and electrophysiologic study of 116 lesions. Neurology 1988;38:1723-8.

2. Van Langenhove $M$, Pollefliet A, Vanderstraeten $G$. A retrospective electrodiagnostic evaluation of footdrop in 303 patients. Electromyogr Clin Neurophysiol 1989; 29:145-52.

3. Katirji B. Peroneal neuropathy. Neurol Clin 1999;17:567-91.

4. Wilbourn AJ. Common peroneal mononeuropathy at the fibular head. Muscle Nerve 1986;9:825-36.

5. Raudino F. Electrophysiological study of peroneal nerve palsy at the fibular head. Electromyogr Clin Neurophysiol 1996;36:439-40.

6. Sunderland S. The anatomy and physiology of nerve injury. Muscle Nerve 1990; 13:771-84.

7. Dauch WA, Fasse A, Brücher K, Bauer BL. Risk factors of unsuccessful outcome after microsurgery in lumbar intervertebral disc disease. Zentralbl Neurochir 1994; 55:144-55.

8. Eysel P, Rompe JD, Hopf C. Prognostic criteria of discogenic paresis. Eur Spine J 1994;3:214-8.

9. Santi MD, Botte MJ. Nerve injury and repair in the foot and ankle. Foot Ankle Int $1996 ; 17: 425-39$.

10. Roganovic Z. Factors influencing the outcome of nerve repair. Vojnosanit Pregl 1998;55:119-31.

11. Mohsenipour I, Friessnig HP, Schmutzhard E. Regression of neurologic deficit after nerve root lesions by lumbar disc herniations. Zentralbl Neurochir 1993;54:58-65.

12. Weber H. Lumbar disc herniation. A controlled, prospective study with ten years of observation. Spine 1983;8:131-40.

13. Mont MA, Dellon AL, Chen F, Hungerford MW, Krackow KA, Hungerford DS. The operative treatment of peroneal nerve palsy. J Bone Joint Surg Am 1996;78:863-9.

14. Andersson GB, Brown MD, Dvorak J, Herzog RJ, Kambin P, Malter A, et al. Consensus summary of the diagnosis and treatment of lumbar disc herniation. Spine 1996;21:75S-78S.

15. Bues $E$, Markakis $E$. The postoperative recovery from neurological losses following medial prolapses of a lumbar disc, and the timing of surgery. Dtsch Z Nervenheilkd 1969;195:6-18.

16. Vastamaki M. Decompression for peroneal nerve entrapment. Acta Orthop Scand 1986;57:551-4.

17. Barrett JP, Downey MS, Hillstrom HJ. Retrospective analysis of neurapraxia and axonotmesis injuries of select peripheral nerves of the foot and ankle and their conservative and surgical treatment (external neurolysis and neurectomy). I Foot Ankle Surg 1999;38:185-93.

18. Styf J. Entrapment of the superficial peroneal nerve. Diagnosis and results of decompression. J Bone Joint Surg Br 1989;71:131-5.

19. Staal A, Gijn van J, Spaans F. Mononeuropathies: Examination, Diagnosis and Treatment 1999 L. Saunders, London.

20. Wiesseman G]. Tendon transfers for peripheral nerve injuries of the lower extremity. Orthop Clin North Am 1981;12:459-67.

21. Jaivin JS, Bishop JO, Braly WG, Tullos HS. Management of acquired adult dropfoot. Foot Ankle 1992;13:98-104. 
22. Prahinski JR, McHale KA, Temple HT, Jackson JP. Bridle transfer for paresis of the anterior and lateral compartment musculature. Foot Ankle Int 1996;17:615-9.

23. Van Meeteren $N$. Modulation of peripheral nerve repair by exercise training and chronic stress in the rat. Thesis Utrecht University; 1994.

24. Jones TA, Schallert T. Use-dependent growth of pyramidal neurons after neocortical damage. J Neurosci 1994;14:2140-52.

25. Cerny K, Perry J, Walker JM. Effect of an unrestricted knee-ankle-foot orthosis on the stance phase of gait in healthy persons. Orthopedics 1990;13:1121-7.

26. Tomaro J, Burdett RG. The effects of foot orthotics on the EMG activity of selected leg muscles during gait. J Orthop Sports Phys Ther 1993;18:532-6.

27. Bruehlmeier M, Dietz V, Leenders KL, Roelcke U, Missimer J, Curt A. How does the human brain deal with a spinal cord injury? Eur J Neurosci 1998;10:3918-22.

28. Cohen LG, Bandinelli S, Topka HR, Fuhr P, Roth BI, Hallett M. Topographic maps of human motor cortex in normal and pathological conditions: mirror movements, amputations and spinal cord injuries. Electroencephalogr Clin Neurophysiol Suppl 1991;43:36-50.

29. Cohen LG, Roth BJ, Wassermann EM, Topka H, Fuhr P, Schultz J, et al. Magnetic stimulation of the human cerebral cortex, an indicator of reorganization in motor pathways in certain pathological conditions. J Clin Neurophysiol 1991;8:56-65.

30. Green JB, Sora E, Bialy Y, Ricamato A, Thatcher RW. Cortical sensorimotor reorganization after spinal cord injury: an electroencephalographic study. Neurology 1998;50:1115-21.

31. Liepert J, Weiller C. Mapping plastic brain changes after acute lesions. Curr Opin Neurol 1999;12:709-13.

32. Hallett M. The plastic brain. Ann Neurol 1995;38:4-5.

33. Appell HJ. Muscular atrophy following immobilisation. A review. Sports Med 1990;10:42-58.

34. Pierre DS, Gardiner P. The effect of immobilization and exercise on muscle function: a review. Physiotherapy Canada 1987;39:24-36.

35. Bramanti P, Santoro A, Santoro G, Trimarchi F, Rizzo GP, S., et al. Denervation muscular atrophy. Studies on the soleus muscle of the albino rat (LM, TEM, immunofluorescence, image analysis). Ital J Anat Embryol 1998;103:45-64.

36. Gogia P, Schneider VS, LeBlanc AD, Krebs J, Kasson C, Pientok C. Bed rest effect on extremity muscle torque in healthy men. Arch Phys Med Rehabil 1988;69:1030-2.

37. Tropp $\mathrm{H}$, Norlin R. Ankle performance after ankle fracture: a randomized study of early mobilization. Foot Ankle Int 1995;16:79-83.

38. Neumann $\mathrm{H}$, O'Shea P, Nielson JP, Climstein M. A physiological comparison of the short-leg walking cast and an ankle-foot orthosis walker following 6 weeks of immobilization. Orthopedics 1989;12:1429-33; discussion 1433-4.

39. Rozier CK, Elder JD, Brown M. Prevention of atrophy by isometric exercise of a casted leg. I Sports Med Phys Fitness 1979;19:191-4.

40. Germain P, Guell A, Marini JF. Muscle strength during bedrest with and without muscle exercise as a countermeasure. Eur J Appl Physiol Occup Physiol 1995;71:342-8.

41. Balmaseda MT, Koozekanani SH, Fatehi MT, Gordon C, Dreyfuss PH, Tanbonliong EC. Ground reaction forces, center of pressure, and duration of stance with and without an ankle-foot orthosis. Arch Phys Med Rehabil 1988;69:1009-12.

42. McCulloch MU, Brunt D, Vander Linden $D$. The effect of foot orthotics and gait velocity on lower limb kinematics and temporal events of stance. J Orthop Sports Phys Ther 1993;17:2-10. 
43. Wiley JP, Nigg BM. The effect of an ankle orthosis on ankle range of motion and performance. J Orthop Sports Phys Ther 1996;23:362-9.

44. Lehmann JF, Condon SM, de Lateur BJ, Smith JC. Ankle-foot orthoses: effect on gait abnormalities in tibial nerve paralysis. Arch Phys Med Rehabil 1985;66:212-8.

45. Lehmann JF, Condon SM, de Lateur BJ, Smith JC. Gait abnormalities in tibial nerve paralysis: a biomechanical study. Arch Phys Med Rehabil 1985;66:80-5.

46. Lehmann JF, Condon SM, de Lateur BJ, Price R. Gait abnormalities in peroneal nerve paralysis and their corrections by orthoses: a biomechanical study. Arch Phys Med Rehabil 1986;67:380-6.

47. Lehmann JF. Push-off and propulsion of the body in normal and abnormal gait. Correction by ankle-foot orthoses. Clin Orthop 1993:288;97-108.

48. Perry J. Kinesiology of lower extremity bracing. Clin Orthop 1974;0:18-31.

49. King LA, VanSant AF. The effect of solid ankle-foot orthoses on movement patterns used in a supine-to-stand rising task. Phys Ther 1995;75:952-64.

50. Beckerman H, Becher J, Lankhorst G), Verbeek AL. Walking ability of stroke patients: efficacy of tibial nerve blocking and a polypropylene ankle-foot orthosis. Arch Phys Med Rehabil 1996;77:1144-51.

51. Fisher LR, McLellan DL. Questionnaire assessment of patient satisfaction with lower limb orthoses from a district hospital. Prosthet Orthot Int 1989;13:29-35. 


\section{Chapter 3}

Effect of immobilization on ankle dorsiflexion strength

JFM Geboers, JH van Tuijl, HAM Seelen, MR Drost

Scand J Rehabil Med 2000:32;66-71 


\section{Abstract}

The present study was performed to determine loss of strength of the dorsiflexors in healthy persons after immobilization of the ankle, and the ability of these muscles to regain strength. First, isometric ankle dorsiflexion strength was measured in 33 healthy male and 39 female subjects in age categories $20-49$ and 50 - 80 years, in order to obtain reference data and to determine the reproducibility of the measurement protocol. Gender, age and ankle position had a significant influence on the ankle dorsiflexion torque. Secondly, torque was measured in 15 patients after 4 to 6 weeks immobilization of the ankle due to a fracture. A $28 \%$ decrease in dorsiflexion torque was seen. Strength reduction in neutral position and in $30^{\circ}$ plantar flexion was not significantly different. Without specific therapy, restoration of torque was almost complete six weeks after cast removal. 


\section{Introduction}

In patients with a paresis of the dorsiflexors, an ankle foot orthosis (AFO) is often prescribed to correct the resulting foot drop and restore walking ability. In clinical practice, two opposing opinions as to the effects of AFO use on the remaining strength and possible restoration of strength do exist. One believes that AFO use by early restoration of walking stimulates muscle synergetic activity and thereby prevents further loss of muscle function. The other opinion is that AFO use impedes ankle movement causing disuse and, by taking over the ankle dorsiflexion function, reduces the existing dorsiflexor muscle activity. Further weakening of the ankle dorsiflexors and a poorer restoration of strength over time would be the result. The clinical relevance of this dilemma is determined by the susceptibility of the dorsiflexors to immobilization atrophy in general. If immobilization does not cause significant strength reduction, AFO use can theoretically not be harmful. The effects of immobilization on muscle strength have been predominantly described in animal studies ${ }^{1}$. Immobilization studies involving human subjects mainly focused on the quadriceps and/or triceps surae muscle 2,3 . The tendency of muscles to weaken during immobilization differs, depending on e.g. muscle type, joint position and duration of immobilization 4,5,6. A problem in the evaluation of immobilization effects is that data available on normal torque values of the dorsiflexor muscles vary largely, suggesting dependency on protocol. Therefore, the aim of the first study was to evaluate our protocol, to determine the reproducibility of ankle torque measurements in healthy adults and to collect reference data from 72 healthy volunteers. A second aim was to study the loss of strength and the extent of spontaneous strength recovery of the dorsiflexors in healthy persons after four to six weeks of total immobilization of the ankle in neutral position, to determine to what extent strength loss of the ankle dorsiflexors occurs in subjects without neurological problems. From fifteen healthy persons who's ankle had been immobilized in a plaster cast because of a fracture of the lower leg, the level of torque reduction immediately after cast removal and torque restoration six weeks afterwards were assessed. This was done in a $0^{\circ}$ and $30^{\circ}$ ankle angle to detect a possible difference in strength reduction due to the position of immobilization.

\section{Methods}

\section{Subjects}

First a reference study was performed to assess the reproducibility of the results measured with the described protocol and to gather reference values. In the reference study, 72 healthy volunteers were included. The group consisted of 33 
men and 39 women recruited from staff and healthy visitors of the rehabilitation clinic. Each subject met the following criteria: age between 18 and 80, no incidence of fracture, trauma or contractures of the lower limbs and no history of musculoskeletal, rheumatologic, neurologic or orthopaedic problems in the lower extremities that would reduce maximum voluntary contraction (MVC).

In the immobilization study 15 persons whose ankle had been immobilized in a weight bearing cast below the knee following a lower leg fracture, participated. The mean duration of ankle immobilization was 40 $(S D=8)$ days. The first measurement took place on average $31(S D=13)$ hours after removal of the cast, the second measurement $43(\mathrm{SD}=3)$ days later. They all met the following criteria: aged between 18 and 80 ; immobilization of the ankle in neutral position during four to six weeks; immobilization due to a lower leg fracture treated without internal fixation around the ankle; capable of performing measurements without risk of reinjury after cast removal; capable of holding the foot in $0^{\circ}$ and $30^{\circ}$ plantar flexion unaided; no ankle complaints or ankle fractures in the past year other than the present pathology and no additional history of musculoskeletal, rheumatologic, neurologic or orthopaedic problems regarding the leg.

The demographic data of both groups are given in Table I.

\section{Table 1}

Group composition in reference study and immobilization study (mean and SD)

\section{Reference study}

\begin{tabular}{llllll}
\hline Gender & Category $(\mathrm{yr})$ & $\mathrm{N}$ & Age $(\mathrm{yr})$ & Height $(\mathrm{m})$ & Weight $(\mathrm{kg})$ \\
\hline \multirow{2}{*}{ male } & $20-49$ & 20 & $34.8(8.8)$ & $1.83(7.2)$ & $80.1(10.4)$ \\
\multirow{2}{*}{ female } & $50-80$ & 13 & $66.6(6.8)$ & $1.77(5.6)$ & $87.1(13.4)$ \\
& $20-49$ & 25 & $32.4(7.8)$ & $1.68(5.6)$ & $66.1(11.1)$ \\
& $50-80$ & 14 & $61.0(5.2)$ & $1.62(5.2)$ & $70.2(21.9)$
\end{tabular}

Immobilization study

\begin{tabular}{lllll}
\hline male & 6 & $33.0(11.1)$ & $1.83(14.0)$ & $90.5(28.7)$ \\
female & 9 & $45.7(8.1)$ & $1.65(6.4)$ & $79.4(10.2)$
\end{tabular}

Patients were recruited from regional hospitals. The study was approved by the local medical ethical committee. All patients signed an informed consent before entering the study. 


\section{Materials}

\section{Test procedure}

In both studies the same test protocol was used. Isometric torque was measured while the subject was in a supine position with the hips slightly flexed and the knee joint angle in neutral $\left(=0^{\circ}\right)$ position. The upper and lower leg were fixed to the examination table with two velcro straps. The foot was positioned against a small horizontally placed plastic beam $(17 \times 2 \mathrm{~cm})$ covered with foam rubber, spanning the whole width of the foot at the level of the first metatarso-phalangeal joint (MTP 1). The foot was not supported below the heel to prevent any heel force to exert a moment around the ankle (Figure 1).

A Tedea-Huntleigh model 601 load cell was used to measure torque. The centre of the beam was in alignment with the centre of the load cell through the use of an U-shaped rigid light weight hook. Calibration of the dynamometer was performed under static conditions with a known weight after each complete session.

\section{Figure 1}

Isometric dorsiflexor torque measurement with the ankle in neutral position $\left(0^{\circ}\right)$. The plastic beam at the level of the MTP joints is connected by a U-shaped hook to a load cell.

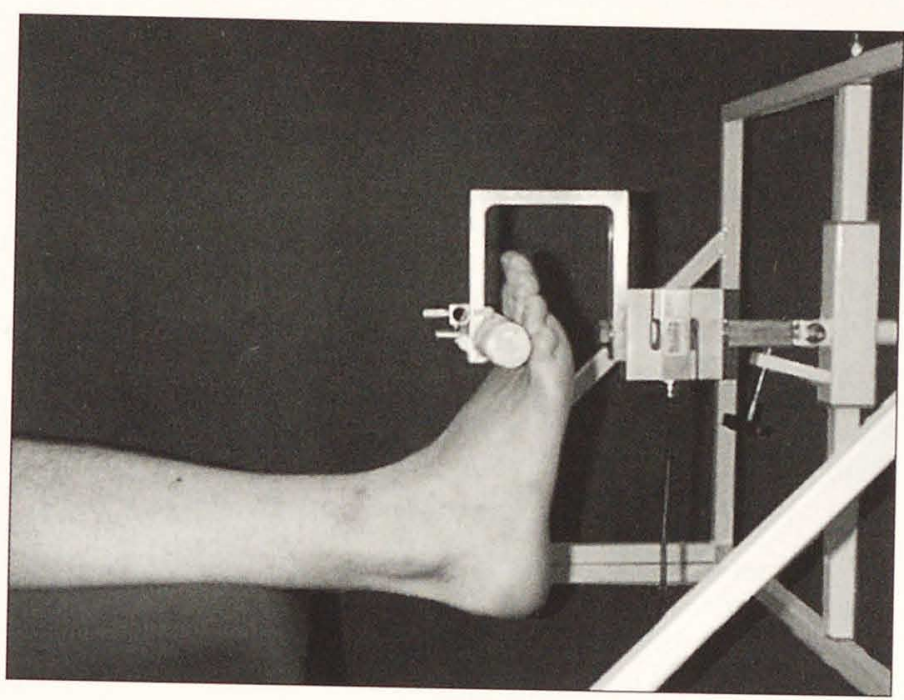

Body weight, height and foot size were registered, and leg dominance was determined by asking participants which leg they preferred for kicking a ball. After five minutes warming up on a home trainer, patients and controls were given standardised verbal instruction to pull the foot against the beam 
with a maximum effort during five seconds. No verbal encouragement was given. Visual feedback was given on the relative strength of the contraction by an analogue gauge. Subjects repeated the contractions ten times with half a minute interval to prevent fatigue. Measurements took place in $0^{\circ}$ and $30^{\circ}$ plantar flexion of the ankle in both legs with a five minutes pause in between. The sequence of measurements was randomly assigned. After completing ten repetitions in one position the distances between the contact area of the dynamometer with MTP1 and the line connecting the apices of the lateral and medial malleolus, representing the position of the ankle flexion axis, were measured $^{7}$. Data acquisition was performed using a 12 bit DT2824 PGL A/D converter board (Data Translation Inc. Marlboro, Mass.) and MUCAPS software (Multi Channel Acquisition and Processing System, iRv, Neth.) with a sample frequency of $500 \mathrm{~Hz}$ and a sample time of ten seconds.

\section{Data analysis}

Strength data were analysed off-line using the MATLAB software package (The Math Works, Natick, Mass.). A one second sustained maximum force effort was calculated from the load cell signal for each trial for each subject using a windowing technique. In order to determine the net muscle strength it is necessary to incorporate the effect of the weight of the foot ${ }^{8}$. The weight of the foot relative to the total body weight is estimated at $1.4 \%{ }^{9}$. This process resulted in ten values, corrected for gravity, for each position for each subject. The three highest values for each position were selected and the average of these three values was used as the maximum value for the subject in that position ${ }^{10}$. This procedure was performed on both reference and patients data. For each of the four experimental conditions of the reference group a within subject coefficient of variation (CV) was calculated. The CV was calculated by dividing the standard deviation of the three maxima in each block by their mean value. Means and standard deviations were calculated for the maxima of all subjects. Since parametric statistics criteria were met, possible influences in results caused by gender $(\mathrm{m} / \mathrm{f})$, age $(20-49 / 50-80)$, ankle angle $\left(0^{\circ} / 30^{\circ}\right)$ or leg dominance $(1 / r)$ in the reference group were each tested using MANOVA and paired t-tests with a $p$-value $<0.05$ as limit for significance. Since the number of participants was relatively small for the immobilization group, possible differences in torque between the two measurement sessions, i.e. immediately after cast removal and six weeks later, were analysed using the Wilcoxon signed ranks test. A similar procedure was performed for the torque production in the two different ankle angles in the latter group. Torque reduction in Table IV is expressed in absolute values (N) and relative (\%) to the value of the healthy side in the second measurement. All statistical analyses were performed by means of SPSS software (SPSS Inc., Chicago, III.). 


\section{Results}

\section{Results reference study}

Reference values of the group of 72 healthy volunteers are presented in Table II. Gender, age and ankle position had a significant influence on the torque produced ( $p$-values between 0.000 and 0.021 ). Neither left or right side nor presumed leg dominance showed a significant relation to torque production. Therefore, henceforth the average of both torque values is used as reference value.

\section{Table II}

Reference values of dorsiflexor muscle strength (mean (SD))

\begin{tabular}{|c|c|c|c|c|c|c|}
\hline \multirow[t]{2}{*}{ Angle } & \multirow[t]{2}{*}{$N$} & \multirow[t]{2}{*}{ Gender } & \multirow[t]{2}{*}{ Age (yr) } & \multicolumn{3}{|c|}{ Torque (Nm) } \\
\hline & & & & right ankle & left ankle & both ankles \\
\hline $0^{\circ}$ & $\begin{array}{l}20 \\
13 \\
25 \\
14\end{array}$ & $\begin{array}{l}\text { Male } \\
\text { Female }\end{array}$ & $\begin{array}{l}20-49 \\
50-80 \\
20-49 \\
50-80\end{array}$ & $\begin{array}{lr}40.9 & (7.4) \\
26.4 & (11.7) \\
31.5 & (6.6) \\
22.7 & (8.0)\end{array}$ & $\begin{array}{lr}42.8 \quad(7.8) \\
28.0(12.4) \\
31.0 \quad(5.9) \\
21.9 \quad(6.8)\end{array}$ & $\begin{array}{l}41.8(7.0) \\
27.2(11.3) \\
31.2(5.9) \\
22.3(7.2)\end{array}$ \\
\hline $30^{\circ}$ & $\begin{array}{l}20 \\
13 \\
25 \\
14\end{array}$ & $\begin{array}{l}\text { Male } \\
\text { Female }\end{array}$ & $\begin{array}{l}20-49 \\
50-80 \\
20-49 \\
50-80\end{array}$ & $\begin{array}{lr}54.4 & (9.5) \\
45.1 & (13.4) \\
39.5 & (6.7) \\
32.8 & (8.7)\end{array}$ & $\begin{array}{l}54.5(10.6) \\
44.4(10.8) \\
38.2(6.3) \\
31.4 \quad(8.7)\end{array}$ & $\begin{array}{l}54.4 \quad(9.5) \\
44.8(11.7) \\
38.9(6.4) \\
32.1 \quad(8.6)\end{array}$ \\
\hline
\end{tabular}

Results of torque measurements of 72 healthy volunteers of the ankle dorsiflexor muscles in $0^{\circ}$ and $30^{\circ}$ plantar flexion of the ankle. Significant differences were found between the two ankle angles, the young and the old group and male and females $(p<0.05)$. No significant differences were found between left or right leg.

\section{Reproducibility}

The CVs of the healthy subjects range from $0.2 \%$ to $18.4 \%$. In general the lowest CVs result from measurements in $30^{\circ}$ (Table III). The mean CV of all measurements was $4.2 \%(S D=3.6)$. Only $7.6 \%$ of all within subject $C V^{\prime} s$ exceeded $10 \%$. 


\section{Table III}

Coefficients of variation of healthy subjects

\begin{tabular}{lccc}
\hline Ankle position & Minimum CV (\%) & Maximum CV (\%) & Mean (SD) CV (\%) \\
\hline $0^{\circ}$ right & 0.3 & 18.2 & $4.8(3.7)$ \\
$0^{\circ}$ left & 0.2 & 18.4 & $4.5(3.8)$ \\
$30^{\circ}$ right & 0.2 & 16.5 & $4.1(4.0)$ \\
$30^{\circ}$ left & 0.3 & 14.6 & $3.2(2.7)$ \\
\hline
\end{tabular}

$\mathrm{CV}$ : coefficient of variation

The maximum torque in each position is measured by averaging the three highest values out of ten attempts. The variation between these values are expressed as coefficients of variation.

\section{Results immobilization study}

Results of the torque measurements of the patients are displayed in Table IV. All patients completed the measurements. No complications or new injury occurred. The mean torque of the non-injured leg of the patients (Table IV) were in the same range as the reference values of the healthy population (Table II). Immediately after removal of the plaster cast the mean torque values in both positions $\left(0^{\circ}\right.$ and $\left.30^{\circ}\right)$ were significantly lower $(p<0.001)$ compared to the noninjured side in measurement two (Table IV), $24 \%$ and $31 \%$ respectively.

\section{Table IV}

Relative and absolute mean (SD) dorsiflexor torque in both the injured and non-injured leg in patients $(n=15)$ following a period of ankle immobilisation, immediately after cast removal (measurement 1 ) and 6 weeks later (measurement 2).

Measurement 1

Measurement 2

\begin{tabular}{|c|c|c|c|c|c|}
\hline & & Injured leg & Non-injured leg & Injured leg & Non-injured leg \\
\hline \multirow[t]{2}{*}{$0^{\circ}$} & Strength $(\mathrm{Nm})$ & $24.6(11.9)^{\star}$ & $36.6(16.2)$ & $33.3(16.6)$ & $33.7(12.5)$ \\
\hline & Relative strength (\%) & $76 \quad(32)^{*}$ & $108 \quad(22)$ & $98 \quad(29)$ & 100 \\
\hline \multirow[t]{2}{*}{$30^{\circ}$} & Strength (Nm) & $29.7(16.3)^{\star}$ & $43.9(16.5)$ & $41.9(19.8)$ & $43.5(15.6)$ \\
\hline & Relative strength (\%) & $69(27)^{\star}$ & 101 (17) & $94 \quad(20)$ & 100 \\
\hline
\end{tabular}

*= significant values, $\mathrm{p}<0.001$

The relative strength in this table is expressed as a percentage of the strength of the healthy side of measurement two. There was no significant difference between the torque values of the healthy side in measurement one or two and between the amount of torque reduction in the two ankle positions in measurement 1 . 
There was a non-significant slight difference in the relative amount of torque preservation in $0^{\circ}$ and $30^{\circ}$ i.e. $76 \%$ and $69 \%$ respectively. In both positions the strength of the dorsiflexors of the injured leg increased significantly during six weeks after cast removal $\left(p=0.003\right.$ in $0^{\circ}$ position and $p=0.002$ in $30^{\circ}$ position). After six weeks the strength of the dorsiflexors of the injured leg did not differ significantly from the strength in the non-injured leg.

\section{Discussion}

\section{Reference values}

The first question of this study was to gather reference data and determine the reproducibility of ankle torque measurements in healthy adults. The absolute values collected in this reference group are in agreement with most other studies (Table V). Only Sepic et al. ${ }^{11}$ found higher torque values. Furthermore, in the reference group we found torque values measured in a $0^{\circ}$ position to be significantly lower than torque values in a $30^{\circ}$ plantar position. These results are in agreement with those found by van Schaik et al. ${ }^{12}$. However, Marsh et al. ${ }^{13}$ and Vander Linden et al. ${ }^{14}$ reported nearly identical torque values in both ankle positions. These conflicting results are probably due to differences in measurement protocols. This stresses the importance of collecting reference values if a different protocol or set up is used. The reference values showed significant differences in torque production between young and old participants as well as between males and females. No significant differences were found between the left and right leg or in relation to leg dominance. These results are in agreement with most other studies as shown in Table $V$. 


\section{Table V}

Literature values of isometric dorsiflexion strength

\begin{tabular}{|c|c|c|c|c|c|c|}
\hline Author & Gender & $\begin{array}{l}\text { Torque in } \mathrm{Nm} \\
\text { Ankle angle } 0^{\circ}\end{array}$ & $\begin{array}{l}\text { mean and SD) } \\
\text { Ankle angle } 30^{\circ}\end{array}$ & $\begin{array}{l}\text { Age } \\
\text { years }\end{array}$ & $N$ & Knee angle \\
\hline Marsh et al. ${ }^{13}$ & $\mathrm{~m}$ & $46.5^{\star}$ & $47^{\star}$ & $19-37$ & 25 & $90^{\circ}$, seated \\
\hline \multirow[t]{4}{*}{ Sepic et al. ${ }^{11}$} & $m$ & $79.3(15.4)^{\star *}$ & & $32.0(2.6)$ & 10 & $90^{\circ}$, seated \\
\hline & $\mathrm{m}$ & $75.6(13.9)^{\star \star}$ & & $56.5(3.2)$ & 10 & \\
\hline & $f$ & $44.7(8.5)^{\star \star}$ & & $29.1(3.2)$ & 10 & \\
\hline & f & $47.3(11.1)^{\star \star}$ & & $54.8(4.0)$ & 10 & \\
\hline \multirow[t]{10}{*}{ Vandervoort et al. ${ }^{35}$} & $\mathrm{~m}$ & & $43.5(6.5)$ & $20-32$ & 11 & $90^{\circ}$, seated \\
\hline & $\mathrm{m}$ & & $37.2(4.3)$ & $40-52$ & 10 & \\
\hline & $\mathrm{m}$ & & $36.2(7.6)$ & $60-69$ & 13 & \\
\hline & $m$ & & $31.6(8.6)$ & $70-79$ & 16 & \\
\hline & $\mathrm{m}$ & & $24.2(7.0)$ & $80-100$ & 13 & \\
\hline & $f$ & & $26.6(4.5)$ & $20-32$ & 11 & \\
\hline & $f$ & & $25.8(6.3)$ & $40-52$ & 10 & \\
\hline & $f$ & & $23.8(3.1)$ & $60-69$ & 10 & \\
\hline & $f$ & & $21.5(3.9)$ & $70-79$ & 16 & \\
\hline & $f$ & & $16.7(4.9)$ & $80-100$ & 13 & \\
\hline Vander Linden et al. ${ }^{14}$ & $\mathrm{~m}$ & $45.1(5.9)$ & $45.2(5.7)$ & $21-35$ & 20 & $90^{\circ}$, prone \\
\hline \multirow[t]{12}{*}{ Vandervoort et al. ${ }^{36}$} & $\mathrm{~m}$ & 42.9 & & $55-60$ & 20 & $0^{\circ}$, prone \\
\hline & $\mathrm{m}$ & 43.1 & & $61-65$ & 18 & \\
\hline & $\mathrm{m}$ & 38.8 & & $66-70$ & 18 & \\
\hline & $\mathrm{m}$ & 36.9 & & $71-75$ & 20 & \\
\hline & $\mathrm{m}$ & 30.8 & & $76-80$ & 18 & \\
\hline & $m$ & 28.7 & & $81-85$ & 17 & \\
\hline & $f$ & 27.0 & & $55-60$ & 16 & \\
\hline & $f$ & 23.6 & & $61-65$ & 17 & \\
\hline & $f$ & 23.6 & & $66-70$ & 17 & \\
\hline & $f$ & 22.6 & & $71-75$ & 18 & \\
\hline & $f$ & 19.4 & & $76-80$ & 17 & \\
\hline & $f$ & 19.0 & & $81-85$ & 18 & \\
\hline \multirow[t]{4}{*}{ Van Schaik et al. ${ }^{12}$} & $\mathrm{~m}$ & $38^{\star}$ & $52^{\star}$ & 20.40 & 15 & $90^{\circ}$, seated \\
\hline & $\mathrm{m}$ & $32^{\star}$ & $43^{\star}$ & $60-80$ & 15 & \\
\hline & $f$ & $22^{\star}$ & $36^{*}$ & $20-40$ & 15 & \\
\hline & $f$ & $18^{*}$ & $30^{\star}$ & $60-80$ & 15 & \\
\hline \multirow[t]{4}{*}{ Hicks et al. ${ }^{37}$} & $m$ & & $48.1(12.1) \#$ & $60-70$ & 25 & $90^{\circ}$, seated \\
\hline & $\mathrm{m}$ & & $47.1(7.6) \#$ & $70-80$ & 19 & \\
\hline & $f$ & & $29.6(7.0) \#$ & $60-70$ & 28 & \\
\hline & $f$ & & $26.7(5.9) \#$ & $70-80$ & 37 & \\
\hline \multirow[t]{4}{*}{ Thelen et al. ${ }^{38}$} & $m$ & & $43(8) \$$ & $19-29$ & 12 & $0^{\circ}$, supine \\
\hline & $\mathrm{m}$ & & $37(5) 8$ & $65-86$ & 12 & \\
\hline & $f$ & & $28(4) \$$ & 19.29 & 12 & \\
\hline & $f$ & & $22(3) \$$ & $65-86$ & 12 & \\
\hline
\end{tabular}

${ }^{*}=$ extrapolated from graph; ${ }^{* *}=$ values divided by ten to convert from $\mathrm{kgcm}$ to $\mathrm{Nm}$; $\#=20^{\circ}$ ankle angle; $\$=10^{\circ}$ ankle angle; $m=$ male; $f=$ female. 


\section{Evaluation of the protocol}

The protocol resulted in reproducible values with a mean $\mathrm{CV}$ of $4.2 \%$ $(S D=3.6)$. During this study all subjects were asked to complete ten contractions in each position. When selecting the three highest contraction values to calculate the maximum torque we found that in most cases they were produced during the first five efforts. Thus it seems the 30 seconds rest in between did not prevent fatigue. Therefore, the protocol can be improved by using five contractions in each position and a longer pause in between.

\section{Torque reduction after immobilization}

The second question we posed was to what extent does strength loss of the ankle dorsiflexors occur after four to six weeks immobilization of the lower leg in subjects without neurological problems. This information would give us insight in the susceptibility of this specific muscle group to immobilization atrophy. Torque reduction after immobilization is mainly due to fibre atrophy, and reduced electromechanical efficiency $2,15,16$. The human tibialis anterior muscle predominantly consists of type I fibres ${ }^{17,18}$. Animal models show a larger sensitivity to strength loss after immobilization in muscles predominantly consisting of type I fibres. The phasic activity of the tibialis anterior muscle on the other hand, might protect against serious torque reduction ${ }^{4}$. In the present study the average loss of strength was $28 \%$, irrespective of sex, age or leg dominance. Because all patients were able to perform the contractions without serious discomfort, the lower torque values immediately after cast removal could not be explained by pain or fear. The values of the present study correspond with those found by Tropp et al. ${ }^{19}$ in isokinetic torque measurements after cast bearing. Other studies ${ }^{2,20,21,22,23}$ concerning human muscle response to immobilization report torque reduction ranging from $59 \%$ in the quadriceps muscle 22 to only $8 \%$ in the ankle dorsiflexors ${ }^{20}$. There are however large differences between the results of these studies, probably due to differences in measurement protocols or subjects. An explanation for the larger amount of torque reduction found in our study and of Tropp et al. ${ }^{19}$ is the fact they both measured patients. All other reported studies dealt with healthy (mostly young, male) volunteers. Possibly those healthy subjects involuntary performed isometric contractions in the cast, of which Rozier et al. ${ }^{24}$ demonstrated the positive effect for the quadriceps, in contrast to the patients with a fracture who will possibly minimise muscle activity around the ankle due to pain or fear. The same explanation could be applied to explain the lesser torque reduction in bed rest studies. Compared to the above mentioned results of torque reduction in different muscles, a decline in torque of $28 \%$ puts the dorsiflexors of the foot high on the rank of muscles susceptible for disuse. 


\section{Ankle joint position during immobilization}

A third question posed was whether a difference in strength reduction of the dorsiflexors measured in a $0^{\circ}$ and $30^{\circ}$ ankle angle could be found immediately after cast removal. Theoretically, the optimum length of the tibialis anterior muscle to generate torque is between $10^{\circ}$ and $30^{\circ}$ plantar flexion ${ }^{13,25}$. The maximum of this force-length relationship can shift due to morphological changes. In the plaster cast the ankle was immobilized in a neutral position, which means a shortened position for the dorsiflexor muscles. Because a muscle will adapt its number of sarcomeres to a shortened position $6,26,27$ we expected a decline in torque production $28,29,30,31$ which would correspond to a shift of the force-length curve to the left. We expected therefore in the first measurement to find the strength loss to be more pronounced in the $30^{\circ}$ position. However, torque reduction in $0^{\circ} \mathrm{immediately}$ after cast removal and six weeks later was not significantly different from that in plantar flexion. Tissue changes that might have occurred due to the shortened immobilization of the tibialis anterior muscle seem to affect the torque production equally in both positions.

\section{Restoration of torque production}

The last question was to what extent does spontaneous strength recovery take place during six weeks after cast removal? Spontaneous recovery of function after resuming activities is often reported. Booth ${ }^{32}$ and Booth \& Seider $^{33}$ described a full restoration of torque and fibre composition after 120 days in rats that had been immobilized for 90 days. Witzmann et al. ${ }^{34}$ found a complete recovery from 6 weeks immobilization in rats after 4 weeks. Jaweed et al. ${ }^{23}$ reported full restoration of strength and fibre composition in human gastrocnemius-soleus muscle in 28 days after a 30 days immobilization period. In our study no significant difference in torque between the injured and noninjured leg was found six weeks after cast removal.

\section{Conclusion}

Human dorsiflexor muscles of the ankle are highly susceptible to strength loss, i.e. $28 \%$ in $40(\mathrm{SD}=8)$ days of immobilization of the ankle in a weight bearing plaster cast. Immobilization with the ankle in a neutral position does not seem to affect the optimal length of this muscle group to produce force. After cast removal full recovery takes place within a period of six weeks without specific therapy. Given the above mentioned torque reduction in healthy subjects, there seems to be a serious risk of further strength loss due to the (partial) immobilization of the ankle for the group of people using an AFO after neurological damage of the peroneal nerve. However, whether these results are also applicable to paretic muscles will be subject to further study. 


\section{References}

1. Musacchia XI, Steffen JM, Fell RD. Disuse atrophy of skeletal muscle: animal models. Exer Sports Sci Rev 1988;16:61-87.

2. Berg HE, Larsson L, Tesch PA. Lower limb skeletal muscle function after 6 weeks of bed rest. J Appl Physiol 1997;82:182-8.

3. Veldhuizen JW. Knee immobilization. Thesis University Maastricht 1995.

4. Appell HJ. Muscular atrophy following immobilisation. A review. Sports Med 1990;1:42-58.

5. St.-Pierre D, Gardiner PF. The effect of immobilization and exercise on muscle function: a review. Physiotherapy Canada 1987;39:24-36.

6. Witzmann FA, Kim DH, Fitts RH. Hindlimb immobilization: length-tension and contractile properties of skeletal muscle. J Appl Physiol 1982; 53:335-45.

7. Lundberg A, Svensson OK, Németh $G$, Selvik G. The axis of rotation of the ankle joint. J Bone Joint Surg 1989;71-B:94-9.

8. Dvir Z. Isokinetic Muscle Testing, Interpretation and Clinical Applications. Singapore: Longman Publishers, 1995.

9. Williams M, Lissner HR. Biomechanics of human motion. WB Saunders, Philadelphia 1962.

10. Heinonen A, Sievänen $\mathrm{H}$, Viitasalo J et al. Reproducibility of computer measurement of maximal isometric strength and electromyography in sedentary middle-aged women. Eur I Appl Physiol 1994;68:310-4.

11. Sepic SB, Murray MP, Mollinger LA, Spurr GB, Gardner GM. Strength and range of motion in the ankle in two age groups of men and women. Am J Phys Med 1986:65;75-84.

12. Schaik CS van, Hicks AL, McCartney N. An evaluation of the length-tension relationship in elderly human ankle dorsiflexors. J Gerontol 1994;49:B121-7.

13. Marsh E, Sale D, McComas AJ, Quinlan J. Influence of joint position on ankle dorsiflexion in humans. J Appl Physiol 1981;51:160-7.

14. Vander Linden DW, Kukulka CG, Söderberg GL. The effect of muscle length on motor unit discharge characteristics in human tibialis anterior muscle. Exp Brain Res 1991;84:210-8.

15. Booth FW. Physiologic and biochemical effects of immobilization on muscle. Clin Orthop Relat R 1987;219:15-20.

16. Dittmer DK, Teasell R. Complications of immobilization and bed rest. Can Fam Physician 1993;39:1428-37.

17. Henriksson-Larsen KB, Lexell J, Sjostrom M. Distribution of different fibre types in human skeletal muscles. I. Method for the preparation and analysis of cross-sections of whole tibialis anterior. Histochem J 1983;15:167-78.

18. Jennekens FGI, Tomlinson BE, Walton JN. Data on the distribution of fibre types in five human limb muscles. I Neurol Sci 1971;14:245-57.

19. Tropp H, Norlin R. Ankle performance after ankle fracture: a randomized study of early mobilization. Foot Ankle Int 1995; 16:79-83.

20. Gogia P, Schneider VS, LeBlanc AD, Krebs J, Kasson C, Pientok C. Bed rest effect on extremity muscle torque in healthy men. Arch Phys Med Rehabil 1988;69:1030-2.

21. Germain P, Güell A, Marini JF. Muscle strength during bedrest with and without muscle exercise as a countermeasure. Eur J Appl Physiol 1995;71:342-8. 
22. Veldhuizen JW, Koene FMM, Oostvogel HJM, Thiel van TPH, Verstappen FTJ. The effects of a supportive knee brace on leg performance in healthy subjects. Int I Sports Med 1991;12:577-80.

23. Jaweed MM, Grana E, Monga TN, Mirabi B. Evaluation of neuromuscular function after 30 days of disuse. In Proceedings PMR Congres Israel 1996.

24. Rozier CK, Elder JD, Brown M. Prevention of atrophy by isometric exercise of a casted leg. I Sports Med Phys Fitness1979;19:191-4.

25. Fischer RD. The measured effect of taping, joint range of motion, and their interaction, upon the production of isometric ankle torques. Athletic Training 1982:218-23.

26. McComas A]. Human neuromuscular adaptations that accompany changes in activity. Med Sci Sports Exer 1994;26:1498-1509.

27. Savolainen J, Myllylä V, Myllylä R, Vihko V, Väänänen K, Takala TES. Effects of denervation and immobilization on collagen synthesis in rat skeletal muscle and tendon. Am / Physiol 1988;254-:897-902.

28. Baker $\mathrm{JH}$, Matsumoto DE. Adaptation of skeletal muscle to immobilization in a shortened position. Muscle \& Nerve 1988;11:231-44.

29. Nicks DK, Beneke WM, Key RM, Timson BF. Muscle fibre size and number following immobilisation atrophy. J Anat 1989; 163:1-5.

30. Sargeant Al, Davies CTM, Edwards RHT, Maunder C, Young A. Functional and structural changes after disuse of human muscle. Clin Sci Molec Med 1977;52:337-42.

31. White MJ, Davies CTM. The effects of immobilization, after lower leg fracture, on the contractile properties of human triceps surea. Clin Sci 1984;66:277-82.

32. Booth FW. Effect of limb immobilization on skeletal muscle. J Appl Physiol 1982; 52:1113-8.

33. Booth FW, Seider MJ. Recovery of skeletal muscle after 3 months of hindlimb immobilizaton in rats. J Appl Physiol 1979;47:435-9.

34. Witzmann FA, Kim DH, Fitts RH. Recovery time course in contractile function of fast and slow skeletal muscle after hindlimb immobilization. I Appl Physiol 1982a; 52:677-82.

35. Vandervoort AA, McComas AJ. Contractile changes in opposing muscles of the human ankle joint with aging. J Appl Physiol 1986;61:361-7.

36. Vandervoort AA, Chesworth BM, Cunningham DA, Paterson DH, Rechnitzer PA, Koval J. Age and sex effects on mobility of the human ankle. I Gerontol 1992; 47:M17-21.

37. Hicks AL, McCartney N. Gender differences in isometric contractile properties and fatigability in elderly human muscle. Can J Appl Physiol 1996;21:441-54.

38. Thelen DG, Schultz AB, Alexander NB, Ashton-Miller JA. Effects of age on rapid ankle torque development. J Gerontol 1996;51A:M226-32. 


\section{Chapter 4}

Immediate and long term effects of an anklefoot orthosis on muscle activity during walking, a randomized study in patients with an unilateral foot drop

JFM Geboers, MR Drost, F Spaans, H Kuipers, HAM Seelen in press Arch Phys Med Rehabil 


\section{Abstract}

\section{Objectives}

To determine whether (1) use of an ankle-foot orthosis (=AFO) by patients with ankle dorsiflexor paresis leads to decreased muscle activity, immediately or after six weeks of AFO use and (2) whether this decrease (if present) differs between healthy and paretic subjects.

\section{Setting}

Rehabilitation research center in the Netherlands.

\section{Design}

Cross-sectional and longitudinal randomized case-control study.

\section{Participants \& Methods}

Muscle activity was measured by surface electromyography (EMG). EMG reproducibility was tested in 14 healthy volunteers walking with and without AFO.

Acute changes in muscle activity from AFO use were compared between 14 healthy persons and the 29 patients with foot drop. Adaptation effects of AFO use after six weeks were studied in 29 patients, a randomly chosen 16 of whom had started using an AFO at the first measurement.

\section{Main outcome measures}

Amount of change in mean rectified EMG activity ( $\delta$-value) between walking with and without AFO. Follow-up measurements were conducted after three and six weeks.

\section{Results}

Correlation coefficients, reflecting within subject reproducibility, varied between 0.68 and 0.96 (mean 0.86). In patients and healthy subjects tibialis anterior muscle activity decreased significantly when using an AFO, respectively $7 \%$ and $20 \%(p=0.01$ and $p=0.04)$. In patients, this decrease was measured in the overall activity during the gait cycle, in healthy subjects, it was measured in the first $15 \%$ of the gait cycle. Overall EMG activity did not change during six weeks. $\delta$-values per muscle did not change during follow-up in the AFO group.

\section{Conclusion}

AFO use immediately reduced muscle activity of the ankle dorsiflexors. However, using an AFO for six weeks did not lead to a general lower EMG activity level nor did the amount of activity reduction accumulate in comparison with patients who did not use an AFO. It is, therefore, safe to use an AFO, even with recently paretic patients. 


\section{Introduction}

In clinical practice, an ankle-foot orthosis (=AFO) is frequently prescribed for patients with paretic ankle dorsiflexor muscles to improve walking ability and prevent stumbling ${ }^{1}$. In subjects with paretic ankle dorsiflexors, an AFO prevents foot drop during the swing phase of gait and helps to control foot placement after heel strike. In treating of patients with a fairly recent paresis, it is important to know whether or not their supported dorsiflexor muscles become less active from the partial immobilization. If they do, this might induce disuse effects during the period of orthosis use, thereby worsening the existing loss of strength and possibly delaying recovery $2,3,4$. Also, because patients often use an orthosis for several months, central adaptation effects may occur that gradually decrease muscle activity over time. Central adaptation of motor representation after peripheral changes such as amputation, spinal cord injury or immobilization has been described by Bruelmeier et al. ${ }^{5}$, Cohen et al. ${ }^{6}$, Green et al. ${ }^{7}$, and Kaas ${ }^{8}$. If, because of AFO use, the central stimulation of the dorsiflexors diminishes, this could result in delayed and decreased strength restoration of the paretic muscles after nerve recovery.

The tibialis anterior muscle (TA) in healthy persons shows a large burst of EMG activity around heel strike to control foot placement in gait ${ }^{9}$. A second burst is seen after toe off during the swing phase to prevent the foot and toes from dropping. The temporal reproducibility of this second burst of the TA is lower than the first ${ }^{10,11,12}$.

AFO use diminishes the possibility for active plantarflexion, inversion and eversion. Gait analyses in subjects with an AFO show alterations in the walking pattern (e.g. the duration of stance phase, the range of motion of the hip and knee joint ${ }^{13,14,15,16,17,18,19}$ ), but in these studies no EMG has been measured. It is conceivable that the supported muscles do show less activity whereas the antagonistic muscles may increase their activity to overcome the restriction in range of motion and the proximal muscle groups to compensate for the extra weight added to the leg. Diaz et al. ${ }^{20}$ and Cerny et al. ${ }^{21}$, for example, found an increase in EMG activity of proximal leg muscles when subjects wore a knee brace that restricted knee extension. Bulthaup et al. ${ }^{22}$ and Janssen et al. ${ }^{23}$ found an increase in proximal muscle activity and a decrease in the activity of the supported wrist extensor muscles in patients with wrist orthoses. However, these studies of muscle reaction to orthosis use were predominantly performed with healthy volunteers or sportsmen with orthopaedic impairment, like instability of the ankle, but with nonparetic muscles.

In view of the previously mentioned studies, some important questions arise. The first is whether dorsiflexor muscles that are supported by an AFO decrease their activity during walking and whether adaptation effects occur after prolonged AFO use. The second question is whether paretic muscles react differently from healthy muscles. 
In this study, the following specific research questions were posed:

1. What is the reproducibility of the EMG signal of the lower leg muscles in healthy persons walking on a treadmill with and without AFO during two consecutive measurement sessions?

2. Do lower leg muscles show an immediate change in mean and initial muscle activity after both healthy volunteers and patients don AFOS?

3. Does the amount of immediate change in muscle activity, ( $\delta$-value), during walking with or without an AFO, differ between healthy subjects and patients?

4. Is there a difference in the change in mean muscle activity ( $\delta$-value) of the lower leg muscles six weeks after initially donning the AFO between patients who do and who do not use an AFO?

\section{Methods}

\section{Subjects}

Fourteen healthy volunteers, 6 men and 8 women with a mean age of 33.2 (SD 10.2) years, recruited from staff and students at our research institute and 29 patients, 21 men and 8 women with a recent unilateral peripheral paresis of the ankle dorsiflexors participated in all studies. Patients were recruited from regional hospitals. Because no exact standard deviations were available, sample size was not based on power analysis but on practical considerations (i.e. availability of patients). Each subject met the following criteria; age above 18 years, peripheral paresis of the foot dorsiflexors for six weeks to one year, strength MRC $1-4^{24}$ (MRC = strength scale $0-5$ of the Medical Research Council), no AFO use, no progressive neurological disease, no contractures of the lower limbs and no history of musculoskeletal, rheumatologic or orthopaedic problems in the lower extremities that prevented a subject from walking at least 500 meters. The healthy volunteers participated in the reproducibility study and the cross-sectional study, the patients participated in both the cross-sectional and longitudinal study. In Table I the group composition is shown. For the longitudinal follow-up study to detect possible adaptation effects of AFO use, the patients were randomly assigned to two groups, without (= No-AFO Group) or with (= AFO Group) daily AFO use. No significant difference was found in the duration and severity of the paresis at the first measurement (TO) between the two patient groups. After the first measurement (T0), the data collection was repeated after three weeks (T3, 21 days, SD 2.6) and again three weeks later (T6, 22 days, SD 3). The study was approved by the medical ethics committees of our research institute and participating hospitals. All patients and healthy controls gave their informed consent. 


\section{Table I}

Demographic characteristics of groups (mean and SD)

\begin{tabular}{lcccc}
\hline Group & $\mathrm{N}$ & Age $(\mathrm{yr})$ & $\mathrm{m} / \mathrm{f}$ & Duration paresis TO (wk) \\
\hline Healthy subjects ${ }^{*} \dagger$ & 14 & $33(10)$ & $6 / 8$ & n.a. \\
No AFO group $\dagger \ddagger$ & 13 & $44(13)$ & $10 / 3$ & $28(8)$ \\
AFO group $\dagger \ddagger$ & 16 & $57(17)$ & $11 / 5$ & $19(13)$ \\
\hline
\end{tabular}

n.a. = not applicable

* = reproducibility study

$\dagger=$ cross sectional study

$\ddagger=$ longitudinal study

\section{Materials}

EMG activity was recorded from the TA, the extensor digitorum longus $(E D L)$, the peroneus longus (PL), the soleus (SOL) and the lateral head of the gastrocnemius muscle (GAS) of the affected leg. The TA and EDL were chosen because they are innervated by the peroneal nerve and specifically act as ankle dorsiflexors. The PL was measured because of its possible role in compensating foot drop by eversion in a paretic leg. The SOL and GAS were measured for the effect of an AFO on the antagonistic muscles. Because electrode placement on the medial head of the GAS was hampered by the AFO, the lateral head was chosen. Surface electromyography was performed using $\mathrm{Ag} / \mathrm{AgCl}$ surface electrodes with a recording surface of $1 \mathrm{~cm}^{2}$. Before applying the electrodes, the skin was cleaned with alcohol. A mould was used to assure an interelectrode distance of $23 \mathrm{~mm}$ during each measurement. Electrodes were placed over the thickest part of the muscle belly. Their location, together with some anatomic structures, were registered on a panty sock to facilitate correct reproduction of the electrode placement during the second and third measurement. Heelstrike was recorded by a microswitch imbedded in the most posterior part of the heel of a regular, off-the-shelf-type of shoe (available in 10 sizes). In this study, muscle activity is represented by the mean rectified EMG activity during one step cycle and the initial activity of the dorsiflexors (TA and EDL) by the first $15 \%$ of the gait cycle because of the specific EMG burst expected. Also, the mean EMG activity of the step cycle as a whole was calculated for all five muscles measured. To test the reliability of our measurement protocol, reproducibility of the EMG measurement was tested in healthy volunteers before the clinical study. 
AFO group participants used their own plastic orthoses during the measurements, the healthy controls and the patient control group used a standard, off-the-shelf, plastic ankle-foot orthosis weighing $125 \mathrm{grams}$, set at $90^{\circ}$, with a posterior trimline to allow some flexibility in ankle movement throughout the gait pattern. The AFOs were available in three sizes.

\section{Test Procedures}

Reproducibility of the EMG test procedure was measured in 14 healthy persons before the clinical study. They were studied twice, one week apart. For the longitudinal study, 29 patients were investigated three times with a three week interval between sessions. Table II presents an overview of the measurement sequences.

\section{Table II}

\section{Measurement scheme}

\begin{tabular}{lcccc} 
Group & TO & T2 & T3 & T6 \\
Healthy subjects & $\dagger^{*}$ & $*$ & & \\
No AFO group & $\dagger \neq$ & & $\ddagger$ & $\ddagger$ \\
AFO group & $\dagger \neq$ & & $\ddagger$ & $\ddagger$ \\
\hline
\end{tabular}

* $=$ reproducibility study

$\dagger=$ cross sectional study

$¥=$ longitudinal study

T0, T2, T3, T6 = measurement session at $0,2,3$ and 6 weeks follow up.

All subjects were measured during walking with and without an AFO in random order. Muscle activity was recorded while walking on a level treadmill (Figure 1). Patients were asked to choose a comfortable walking speed. This speed was also used during the next measurements. If patients normally used a walking aid, they used the treadmill's side bar for support. After a warm-up of approximately 2 minutes, muscle activity and heel strike were recorded during 5 trials of 20 seconds each at a sample rate of $1000 \mathrm{~Hz}$. 


\section{Figure 1}

A patient walking on a level treadmill

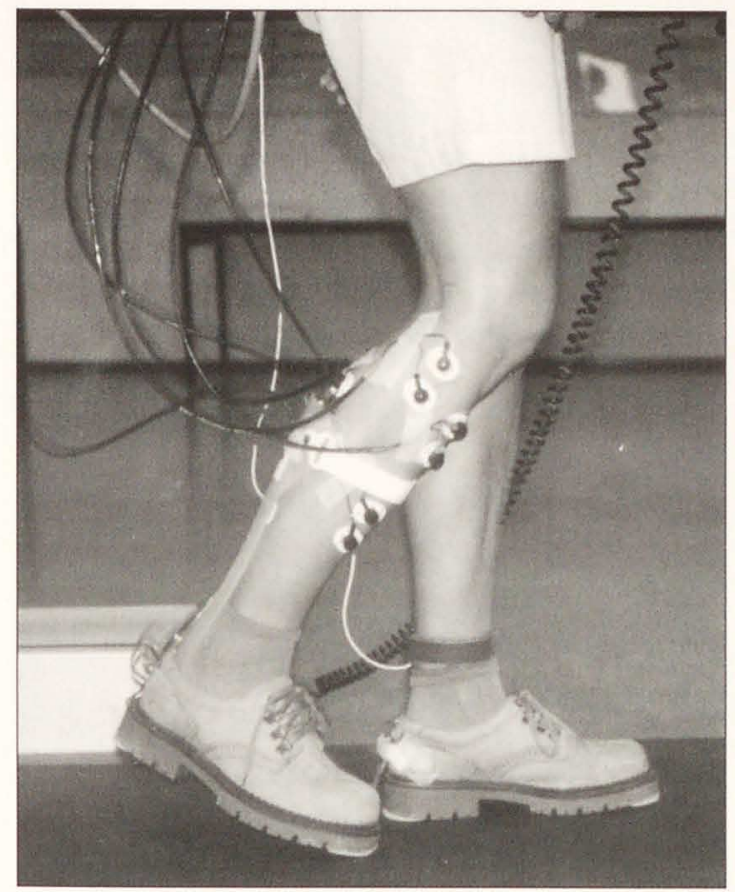

Electrodes on the TA, EDL, PL, SOL and the lateral part of the GAS (below the AFO).

\section{Data analysis}

The EMG signal was full wave rectified and filtered using a Butterworth second-order, low-pass filter with a cutoff frequency of $5 \mathrm{~Hz}$ using the MATLAB software package. A similar procedure was used in gait analysis by Winter ${ }^{25,26}$. The EMG signal was standardized to the gait cycle using heel strike as a reference. Mean EMG activity of each muscle was calculated over the total number of steps in all five trials. This mean EMG activity $(\mu \mathrm{V})$ was considered an indicator of the effort the muscle delivered during walking. The effect of AFO use on muscle activity of each person was expressed as the percentage of change in muscle activity ( $\delta$-value) when walking with an AFO compared with when walking without an AFO. The first $15 \%$ of the step cycle after heel strike was considered the most consistent period of eccentric activity of the ankle dorsiflexors. For all EMG calculations, the mean, the 95\% confidence interval of the mean, and the median are given. 
All statistical analysis were performed with SPSS software. The withingroup values were analysed with the Wilcoxon signed rank test, the between groups values were tested with the Mann-Whitney $U$ test.

In the healthy volunteers, reproducibility of the EMG measurement protocol was determined within each subject for the consecutive measurements for each of the five registered muscles.

Error Analysis

All measurements of the healthy control group were used. In the paretic group, two patients had bad registration caused by signal recording problems. Their data were excluded from further analysis. These two patients were both from the AFO Group. Thus, comparison between the patient groups was performed with 13 subjects in the no-AFO Group and 14 in the AFO Group.

\section{Results}

\section{Reproducibility}

The differences in mean EMG production between the first and second measurement session were calculated for each muscle with and without AFO use. EMG activity, shown in Table III, between T0 and T2 was not significantly different.

\section{Table III}

Differences in mean EMG activity of 14 healthy subjects at two measurement sessions, for walking with and without AFO.

\begin{tabular}{|c|c|c|c|c|c|c|c|}
\hline & TA & & $\mathrm{DL}$ & & SOL & GAS & PL \\
\hline - AFO & $0(13) \%$ & -9 & (23) \% & 2 & (14) \% & -17 (53) \% & $-6(23) \%$ \\
\hline + AFO & $2(27) \%$ & -13 & (31) \% & -0 & (16) \% & 4 (39) \% & $-3(27) \%$ \\
\hline
\end{tabular}

Note: values expressed as (T2-T0)/T2 $\times 100 \%$ (SD)

Reproducibility of the EMG patterns in healthy subjects, expressed as the correlation coefficient, was very good when walking without an AFO, (i.e. $r \geq 0.9$ (Table IV)). With the exception of the PL, walking with an AFO resulted in a lower reproducibility, (i.e. $r \leq 0.81$ for all muscles). The GAS showed the lowest value. 
Table IV

Median correlation coefficient (SD) of the EMG pattern in 14 healthy subjects while walking with and without AFO, for each muscle.

\begin{tabular}{lccccccc}
\hline & \multicolumn{2}{c}{ TA } & \multicolumn{2}{c}{ EDL } & SOL & GAS & PL \\
\hline - AFO & $0.96(0.26)$ & 0.91 & $(0.28)$ & $0.96(0.26)$ & $0.90(0.29)$ & $0.90(0.25)$ \\
+ AFO & 0.81 & $(0.51)$ & 0.79 & $(0.48)$ & $0.80(0.28)$ & $0.68(0.33)$ & $0.93(0.44)$
\end{tabular}

\section{Immediate changes in EMG activity after donning an AFO in healthy and paretic subjects}

There were large interindividual differences in patients' EMG patterns. In most patients, the EMG activity of the TA, for example, did not show the typical pattern, of an initial burst in the first $15 \%$ of the gait cycle, that was seen in the healthy group, as illustrated in Figure 2.

\section{Figure 2}

EMG pattern of healthy and paretic TA
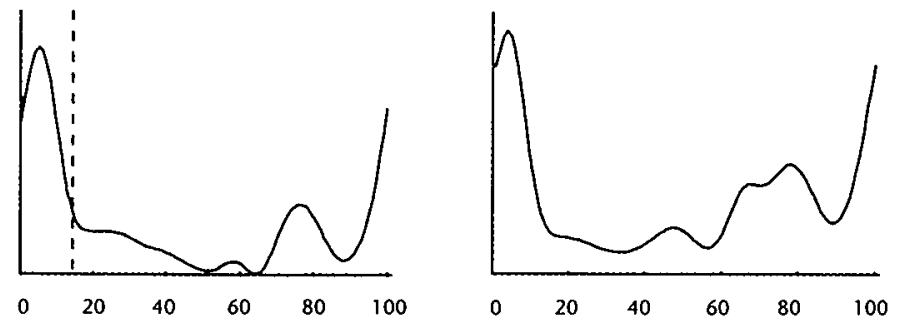

Paretic TA EMG pattern
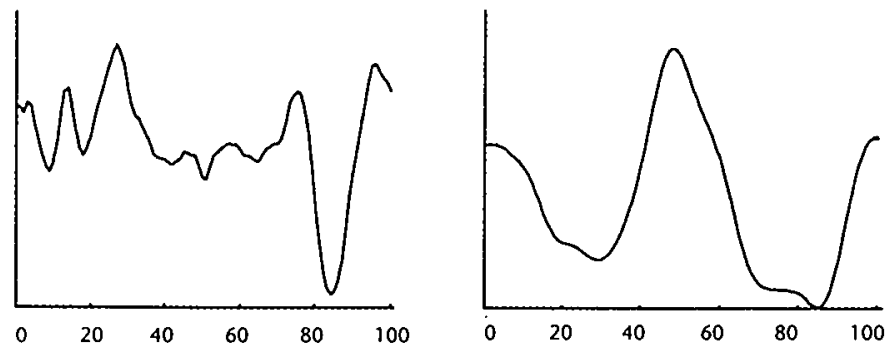

Random example of mean rectified filtered EMG pattern of TA during a step cycle for two healthy and two paretic subjects. The 15\% border is indicated. 
The mean immediate changes in EMG activity after subjects donned an AFO are represented in Figure 3 and 4 for all muscles for the healthy and paretic subjects. When an AFO was used by healthy subjects, EMG activity of the TA and EDL decreased during the first $15 \%$ but not during the step cycle as a whole. In contrast, in paretic subjects these activities decreased during the step cycle as a whole but not specifically during the first $15 \%$.

\section{Figure 3}

Mean immediate change in muscle activity with AFO use per muscle, for paretic and healthy subjects, standard error of the mean (SEM) and median.

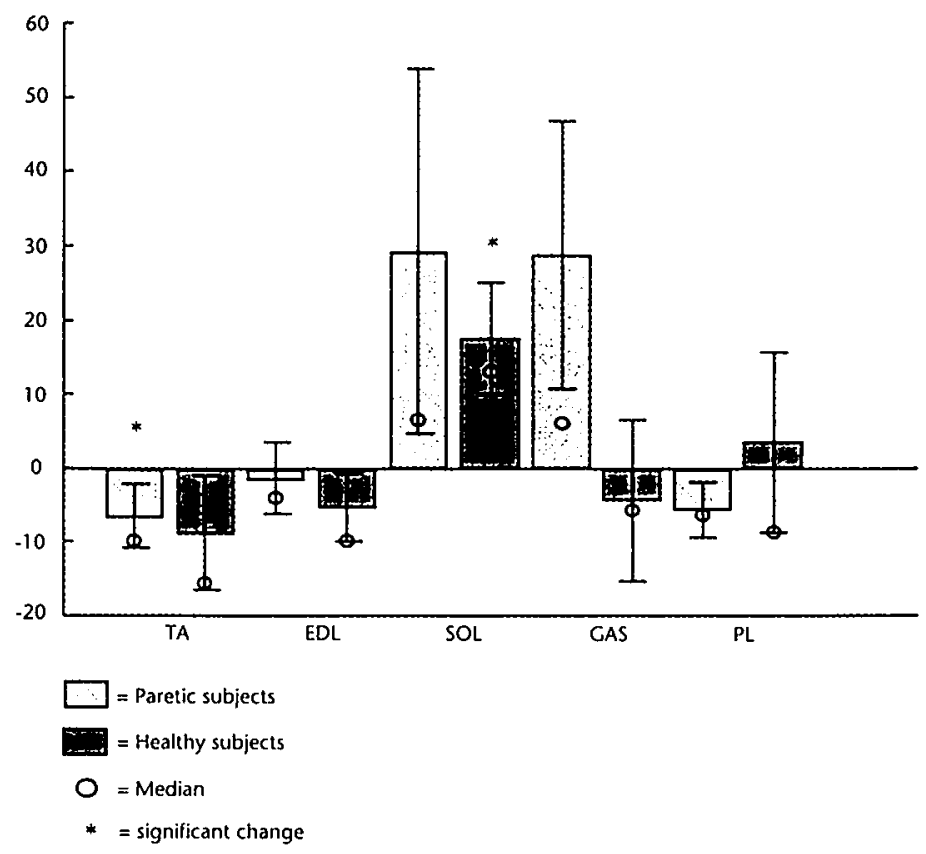




\section{Figure 4}

Mean immediate change in muscle activity in the first $15 \%$ of the gait cycle for respectively paretic and healthy dorsiflexors, standard error of the mean (SEM) and median.

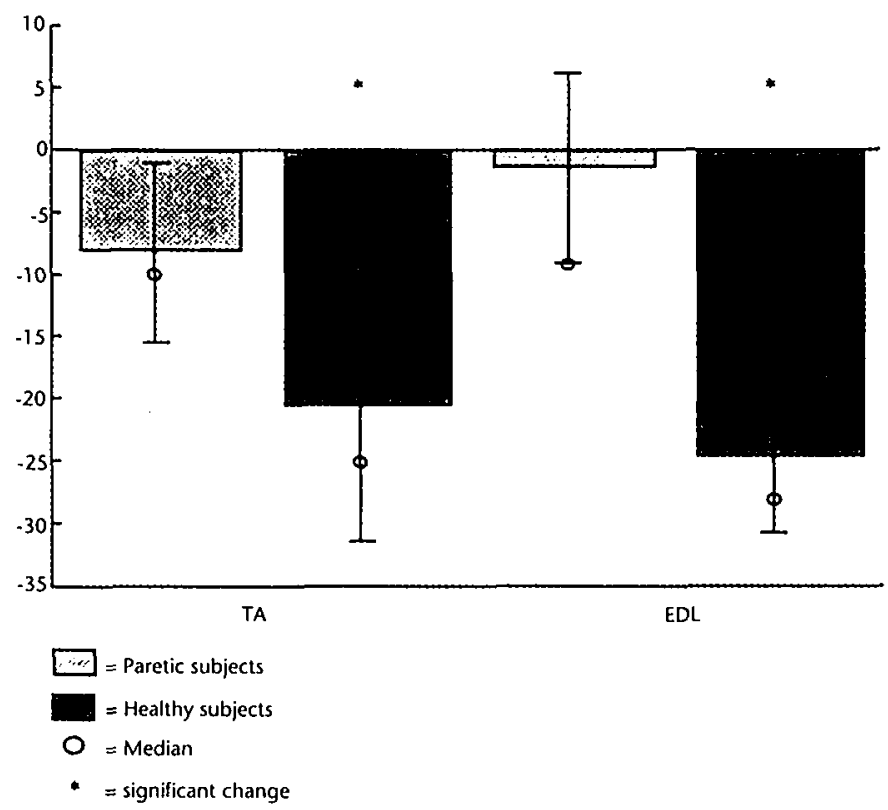

\section{Differences in immediate EMG change ( $\delta$-value) between healthy and paretic subjects}

Between the groups, no difference were found in the amount of EMG change for any muscle, either in the step cycle as a whole, or in the first $15 \%$ as is illustrated in Figure 3 and 4 respectively. The healthy group seemed to show a larger decrease in EMG activity of the TA and EDL than did the paretic group, especially in the first $15 \%$ of the step cycle. However, the difference was not significant.

\section{Differences in muscle activity changes at 6 weeks follow-up between both patient groups}

The total amount of EMG activity did not change between T0 and T6 for either patient group in both conditions. Also, the amount of muscle reaction ( $\delta$-value) after putting on an AFO did not change significantly between or within groups from T0 and T6. EMG activity changes were calculated for the 
step cycle as a whole. Measurements of the first $15 \%$ of the step cycle were not represented because in the paretic subjects this specific first EMG burst was not found consistently. Figure 5 shows the fairly consistent reaction pattern over the three measurement sessions. This means that no adaptation effect of AFO use could be shown.

\section{Figure 5}

Relative change in EMG activity of the TA, EDL,GAS, SOL and PL in the no-AFO Group and AFO Group at T0, T3 and T6.

(Mean (solid line), SEM, and median (broken line))
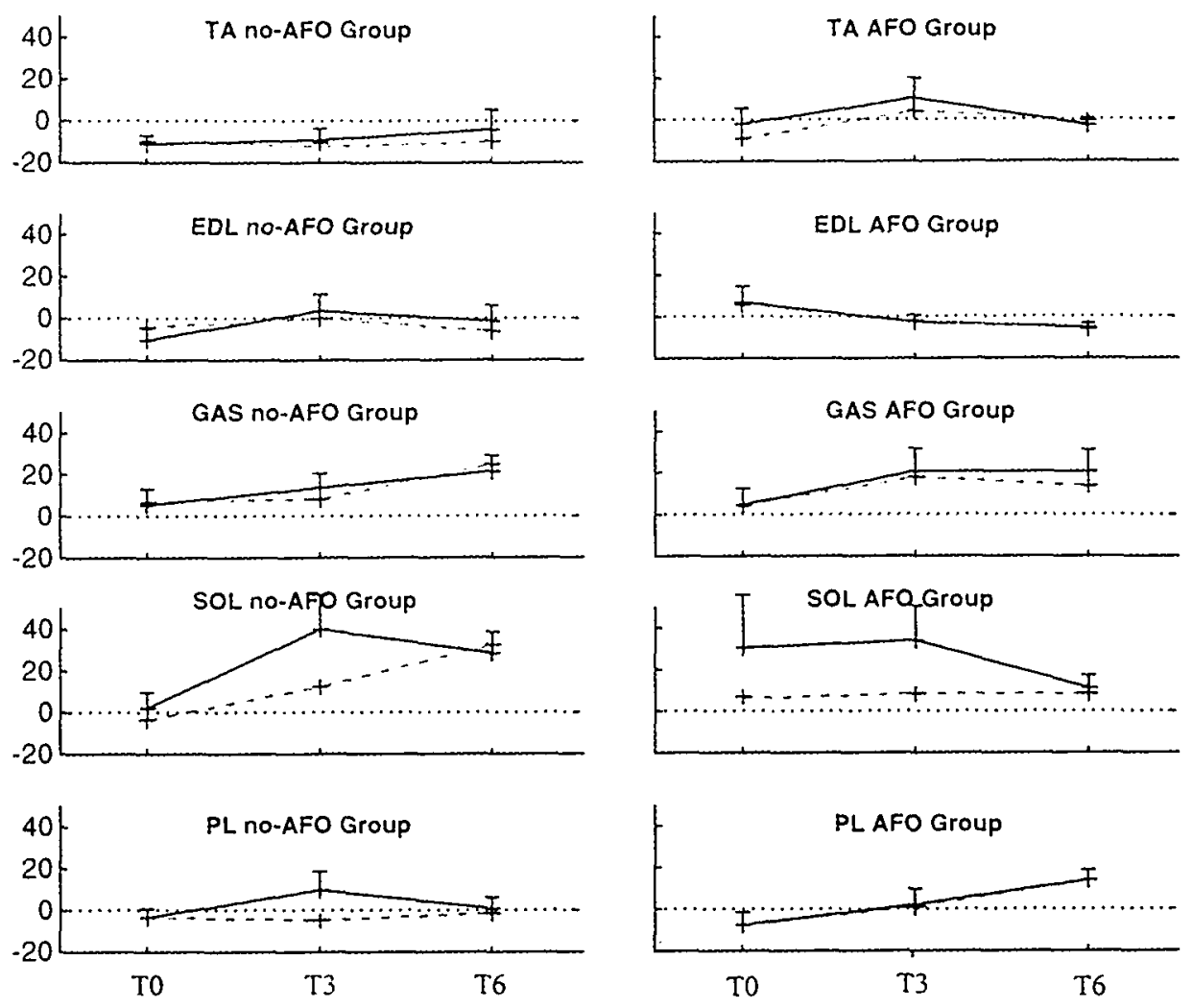


\section{Discussion}

In clinical practice, the question often arises whether an orthosis diminishes muscle activity, thereby worsening an existing paresis. In a case of foot drop, an AFO is often prescribed to restore a more normal and safe walking pattern. In this study, we evaluated the effect of AFO use on EMC activity of five lower leg muscles in healthy and recent paretic subjects. We found a significant decrease of $7 \%$ and $20 \%$ in respectively paretic and healthy subjects in TA activity when an AFO was used but during different phases of the gait cycle. In the paretic group, EMC activity decreased when calculated over the step cycle as a whole, and it decreased in healthy subjects in the first $15 \%$. We could not show an adaptation effect during six weeks of AFO use in the patient group.

This study addressed the problem through four separate questions discussed later. Our first question focused on the reproducibility of the EMG measurements in healthy volunteers. The reported correlation coefficient for the within subject reproducibility proved to be good for most muscles and is in accord with Winter et al. ${ }^{27}$.

Second, we wanted to know whether there was a change in muscle activity when people with or without paresis used an AFO. We found a significant decrease of TA muscle activity in healthy persons in the first $15 \%$ of the gait cycle and in paretic muscles during the entire gait cycle. However, the variability in motor patterns during the gait cycle was much larger in the paretic group, causing the first $15 \%$ of the gait cycle to be not specific for the TA. For the calf muscles in the healthy subjects, there was also a significant decrease of the overall activity of the SOL in the AFO condition. The GAS showed a large variability in activity levels in both patients and healthy subjects in its reaction to AFO use. This corroborated the observation that while walking on the treadmill, several persons tried to plantar flex their ankle during toe-off, although they were restricted in this direction by the AFO. These differences in reacting to the restriction in range of motion of the ankle, in healthy subjects as well as in patients, explain the large interindividual variety in EMG changes with AFO use, which is reflected in the large SD for the calf muscles.

Third, we questioned whether the amount of change in reaction to AFO use differed between paretic muscles and healthy muscles. We found no significant differences in the amount of change in muscle activity after donning the AFO for either muscle between healthy and paretic persons. However, the healthy subjects did specifically show a decrease in EMC activity during the first burst of the TA immediately after heel strike, whereas the paretic subjects showed a decrease in overall EMG activity during the step cycle. This means that results of studies of muscle activity patterns in healthy subjects cannot be extrapolated to patients without careful consideration. 
A possible difference in reaction pattern, and especially a much larger variety, must be expected in paretic muscles.

Finally, we asked whether an adaptation phenomenon occurred in the amount of activity of the supported paretic muscles in a six weeks follow-up period. We found no significant changes during that period in the amount of EMG change after putting on an AFO within or between the groups at the first and last measurement (i.e. an adaptation effect over time was not found). The immediate drop in EMG activity of the TA in AFO use may have accumulated after a longer period of orthosis use, thus enlarging the $\delta$-value between T0 and T6. Or, if the muscle had adapted to the lower EMG activity level during AFO use, walking with or without AFO would generate the same values, lowering the $\delta$-value between T0 and T6. However, because this was not shown, AFO use by recently paretic patients seems not to induce significant changes in muscle reaction after six weeks of daily use, compared with the immediate reaction. If, however, patients are more active with an AFO because they feel safer, or because walking is easier than it is without AFO, this might have a stimulating effect on nerve recovery, as shown by van Meeteren et al. ${ }^{28}$ in a rat model.

Differences in walking velocity between the subjects were not taken into account as a variable to explain our data because the walking velocities during the different measurements were nearly identical. Earlier studies by McCulloch et al. ${ }^{29}$ and Yang et al. ${ }^{30}$ showed no significant changes in EMG patterns in subjects walking at different speeds. Because the relative changes were used to compare between subjects, no significant influence of walking speed was expected.

Also, it is not likely that AFO use would significantly influence the muscle patterns because of its weight. The weight of a standard AFO is only 125 gram. For a man of $80 \mathrm{~kg}$ the moment of inertia for the leg is raised by only $3.4 \%$ from $0.291 \mathrm{~kg} / \mathrm{m}^{2}$ to $0.301 \mathrm{~kg} / \mathrm{m}^{2} 31$.

Finally, the strict inclusion criteria (i.e. only subjects with a recent peripheral paresis MRC 1 -4) resulted in a relatively small sample size. This might have caused small changes to not be identified as statistically significant, although some statistical significant differences were found. Also, we used only one type of AFO, to limit variances in EMG that might be caused by the use of different materials or shapes. The ultimate effect of AFO use on strength production after six weeks is reported in a separate article ${ }^{32}$. 


\section{Conclusion}

Although AFO use significantly reduces EMG activity of the TA in healthy and paretic subjects, respectively with $20 \%$ during the first $15 \%$ of the step cycle and with $7 \%$ calculated over the step cycle as a whole, this reduction does not accumulate over time. This decrease in EMC activity during AFO use is easily compensated for by an increase in total walking activity facilitated by AFO use. Therefore, even in recent paretic subjects, no contraindication exists for AFO use to enhance walking safety. 


\section{References}

1. Jaivin JS, Bishop JO, Braly WG, Tullos HS. Management of acquired adult dropfoot. Foot Ankle Int 1992;13:98-104.

2. Appell HJ. Muscular atrophy following immobilisation. A review. Sports Med 1990;1:4258.

3. Tropp $H$, Norlin R. Ankle performance after ankle fracture: a randomized study of early mobilization. Foot Ankle Int 1995;16:79-83.

4. Geboers JFM, van Tuijl JH, Seelen HAM, Drost MR. Effect of immobilization on ankle dorsiflexion strength. Scand I Rehab Med 2000;32:66-71.

5. Bruehlmeier M, Dietz V, Leenders KL, Roelcke U, Missimer J, Curt A. How does the human brain deal with a spinal cord injury? Eur J Neurosci 1998;10:3918-22.

6. Cohen LG, Bandinelli S, Topka HR, Fuhr P, Roth B], Hallett M. Topographic maps of human motor cortex in normal and pathological conditions: mirror movements, amputations and spinal cord injuries. Electroencephalogr Clin Neurophysiol Suppl 1991;43:36-50.

7. Green JB, Sora E, Bialy Y, Ricamato A, Thatcher RW. Cortical sensorimotor reorganization after spinal cord injury: an electroencephalographic study. Neurology 1998:50;1115-21.

8. Kaas JH, Merzenich MM, Killackey HP. The reorganization of somatosensory cortex following peripheral nerve damage in adult and developing mammals. Ann Rev Neurosci 1983;6:325-56.

9. Dubo HI, Peat M, Winter DA, Quanbury AO, Hobson DA, Steinke T, Reimer G. Electromyographic temporal analysis of gait: normal human locomotion. Arch Phys Med Rehabil 1976;57:415-20.

10. Basmajian JV, Luca CJ de. Muscles alive, their function revealed by electromyography. Williams and Wilkins Baltimore 1985.

11. Shiavi R. Electromyographic patterns in adult locomotion: a comprehensive review. I Rehab Res Dev 1985;22:85-98.

12. Kameyama O, Ogawa R, Okamoto $T$, Kumamoto $M$. Electric discharge patterns of ankle muscles during the normal gait cycle. Arch Phys Med Rehabil 1990;71:969-74.

13. Lehmann JF, Condon SM, Lateur de B], Smith JC. Gait abnormalities in tibial nerve paralysis: a biomechanical study. Arch Phys Med Rehabil 1985;66:80-5.

14. Lehmann JF, Condon SM, Lateur de BJ, Smith JC. Ankle-foot orthoses: effect on gait abnormalities in tibial nerve paralysis. Arch Phys Med Rehabil 1985;66:212-8.

15. Lehmann JF, Condon SM, Lateur de BJ, Price R. Gait abnor-malities in peroneal nerve paralysis and their corrections by orthoses: a biomechanical study. Arch Phys Med Rehabil 1986;67:380-6.

16. Lehmann JF. Push-off and propulsion of the body in normal and abnormal gait. Correction by ankle-foot orthoses. Clin Orthop 1993;288:97-108.

17. Perry J. Kinesiology of lower extremity bracing. Clin Orthop 1974;102:18-31.

18. Perry J. Gait analysis. 1992 Slack Inc New York.

19. Balmaseda MT, Koozekanani SH, Fatehi MT, Gordon C, Dreyfuss PH, Tanbonliong EC. Ground reaction forces, center of pressure, and duration of stance with and without an ankle-foot orthosis. Arch Phys Med Rehabil 1988;69:1009-12.

20. Diaz GY, Averett DH, Soderberg GL. Electromyographic analysis of selected lower extremity musculature in normal subjects during ambulation with and without a Protonics knee brace. J Orthop Sports Phys Ther 1997;26:292-8. 
21. Cerny K, Perry J, Walker JM. Effect of an unrestricted knee-ankle-foot orthosis on the stance phase of gait in healthy persons. Orthopedics 1990;13:1121-7.

22. Bulthaup S, Cipriani DJ, Thomas JJ. An electromyography study of wrist extension orthoses and upper-extremity function. Am J Occup Ther 1999;53:434-40.

23. Jansen CW, Olson SL, Hasson SM. The effect of use of a wrist orthosis during functional activities on surface electromyography of the wrist extensors in normal subjects. J Hand Ther 1997; 10:283-9.

24. Medical Research Council. Aids to the examination of the peripheral nervous system. Her Majesty's Stationary Office, London, 1976.

25. Winter DA. Pathologic gait diagnosis with computer-averaged electromyographic profiles. Arch Phys Med Rehabil 1984;65:393-8.

26. Winter DA. Linear envelope EMG as a biomechanical variable in the assessment of human movement. Electromyographical Kinesiology 1991; 197-200. Editors PA Anderson.

27. Winter DA, Yack HJ. EMG profiles during normal human walking: stride-to-stride and inter-subject variability. Electroencephalogr Clin Neurophysiol 1987;67:402-11.

28. Meeteren van NLU, Brakkee JH, Hamers FPT, Helders PJM, Gispen WH. Exercise training improves functional recovery and motor nerve conduction velocity after sciatic nerve crush lesion in the rat. Arch Phys Med Rehabil 1997;78:70-7.

29. McCulloch MU, Brunt D, Linden vander D. The effect of foot orthotics and gait velocity on lower limb kinematics and temporal events of stance. JOSPT 1993;17:2-10.

30. Yang IF, Winter DA. Surface EMG profiles during different walking cadences in humans. Electroencephalogr Clin Neurophysiol 1985;60:485-91.

31. Winter DA. Biomechanics and motor control of human movement. 2nd ed. New York: John Wiley \& Sons, Inc; 1990.

32. Geboers JFM, Janssen-Potten YJM, Seelen HAM, Spaans F, Drost MR. Evaluation of effects of ankle-foot orthosis use on strength restoration of paretic dorsiflexors. Arch Phys Med Rehab 2001;82:856-60. 
Chapter 4 


\section{Chapter 5}

Evaluation of effect of ankle-foot orthosis use on strength restoration of paretic dorsiflexors

JFM Geboers, YJM Janssen-Potten, HAM Seelen, F Spaans, MR Drost

Arch Phys Med Rehabil 2001:82;856-60 


\section{Abstract}

\section{Objectives}

To assess whether a difference exists in restoration of strength between patients with a recent paresis of the dorsiflexors of the ankle using an anklefoot orthosis (= AFO) and patients without an AFO.

\section{Setting}

Patients from regional hospitals, tested in a Rehabilitation research Center.

\section{Design}

Prospective case-control study

\section{Participants}

29 patients with a recent ( 6 weeks- 1 year) peripheral paresis, alternately assigned to a group using an AFO or a control group. There was no significant difference in duration of the paresis and in torque at entering the study (TO) between the two groups.

\section{Main Outcome Measures}

Isometric torque production of ankle dorsiflexors, expressed as ratio of paretic and healthy side, in two measurement sessions, over a period of six weeks (TO-T6) with the ankle in $0^{\circ}$ and $30^{\circ}$ plantar flexion.

\section{Results}

Both groups had significant restoration of strength between T0 and T6 in $30^{\circ}$; no-AFO group $17 \%(\mathrm{SD}=15)$, AFO-group $9 \%(\mathrm{SD}=12)$. There was no significant difference between the two groups $\left(30^{\circ}: p=0.56\right)$. No significant shift in strength ratio $0^{\circ}: 30^{\circ}$ occurred (AFO-group $p=0.82$ ).

\section{Conclusion}

The use of an orthosis does not influence restoration of strength in patients with a recent peripheral paresis of the ankle dorsiflexors. 


\section{Introduction}

Compression of the deep peroneal nerve may cause a paresis of the toe extensors and ankle dorsiflexors and consequently foot drop during walking. In $20-30 \%$ of the cases, this paresis is the result of a compression neuropathy with a segmental demyelination and a good prognosis of recovery in six to eight weeks. Regeneration takes months, however, when, beside demyelination, partial axon loss is involved, as is the case in $45-50 \%$ of the peroneal neuropathies 1,2 . During this time it is important to prevent disuse effects in the paretic muscles ${ }^{3,4}$. Within two to six weeks after nerve damage a decrease in fibre number, fibre size and loss of electromechanical efficiency are known to develop $p^{4,5,6,7,8}$. Additional effects due to disuse reinforce these changes ${ }^{9,10,11,12}$. For the human dorsiflexors of the foot it is known that they are susceptible to disuse due to immobilization. In healthy persons torque reduction after four to six weeks of cast wearing because of an ankle fracture was found to be $28 \%{ }^{13}$ and $22-32 \%{ }^{14}$.

Two opposing views of the effect of the use of an ankle-foot orthosis (AFO) on muscle strength exist. An AFO could cause further loss of strength due to the partial immobilization (disuse) or could stimulate the patient to walk and thus activate the paretic muscles. This causes a dilemma for the physician whether or not to prescribe one, to facilitate walking and protect the ankle ligaments in patients with a fairly recent paresis of the dorsiflexors. Literature on orthotic use predominantly describes the effect of braces or orthoses in healthy volunteers, or sportsmen after an injury or operation $15,16,17,18,19$. However, it is uncertain whether results of immobilization studies performed in healthy subjects are valid in patients with paretic muscles.

If, on the other hand, patients are more active with an orthosis, more (isometric) muscle action may have a positive result on strength as described in healthy volunteers by Neumann et al. ${ }^{20}$, Rozier et al. ${ }^{21}$, and Germain et al. ${ }^{22}$ and in patients with an ankle fracture by Tropp and Norlin ${ }^{14}$. Also, positioning paretic muscles in an optimal starting angle to perform a contraction i.e., a shortened position closer to the optimal length for generating force, might enhance muscle activity during walking and thus preserve muscle strength ${ }^{23}$. An additional effect of this altered contraction angle might be a shift in the optimum of the force - length curve of the dorsiflexors. In short, it is unknown whether giving an AFO to a patient with a recent paresis will have an additional disuse effect or a stimulating effect on the remaining muscle strength.

The present study investigated the results of AFO use on torque changes in patients with a recent paresis of the ankle dorsiflexors during six weeks follow-up. The following main question was posed: Does the change in isometric strength of patients with recent paretic ankle dorsiflexors differ between AFO users and controls without AFO over a six week period at six weeks tot 1 year postinjury? 
Second, as a possible side effect of AFO use, the question was posed: Does the strength ratio $0^{\circ}-30^{\circ}$ plantarflexion shift during the six weeks, indicating a shift in the optimal angle?

\section{Methods}

\section{Participants}

Twenty-nine patients participated in the study. Because no exact figures for power analysis were available, sample size was based on practical considerations, such as availability of patients. Each subject met the following criteria: age over 18 years, peripheral paresis of the foot dorsiflexors for six weeks to one year, MRC 1-4 (grading from $0=$ paralysis to $5=$ strength overcoming resistance) ${ }^{24}$, torque ratio of paretic side/healthy side $<1$, no AFO use, no progressive neurologic disease, no contractures of the lower limbs and no history of musculoskeletal, rheumatologic or orthopaedic problems in the lower extremities preventing walking for at least 500 meters. Patients from regional hospitals were asked by their specialist or by letter to take part in this study. After their consent, they were, in order of enrolment, divided into two groups, with or without AFO. The study was approved by the medical ethics committee. The first measurement took place at T0, the second measurement (T6) six weeks (42.5 days, SD 2.3) afterwards. Three patients of the 29 were excluded from the study because the ratio paretic side/healthy side exceeded one. Two patients had been enrolled in the no-AFO group, one in the AFO group. Table I shows the final group composition of the participants.

Table I

Group composition (mean and SD)

\begin{tabular}{lcccccc}
\hline & N & Age $(\mathrm{yr})$ & \multicolumn{2}{c}{$\begin{array}{c}\text { Diagnosis } \\
\text { L5 lesion } \\
\text { peroneal nerve } \\
\text { compression }\end{array}$} & $\begin{array}{c}\text { Duration paresis T0 } \\
\text { peroneal nerve } \\
\text { trauma }\end{array}$ \\
\hline $\begin{array}{l}\text { No AFO group } \\
\text { AFO group }\end{array}$ & 11 & $42(13)$ & 6 & 4 & 1 & $26(17) \mathrm{wk}$ \\
\hline
\end{tabular}

No significant difference existed in duration and severity of the paresis (as percentage strength loss compared with the healthy side) at T0 between the two groups. The range of the duration of the paresis at T0 is plotted in Figure 1. 
Figure 1

Duration of paresis at T0 for Group 1 (no AFO) and 2 (AFO)

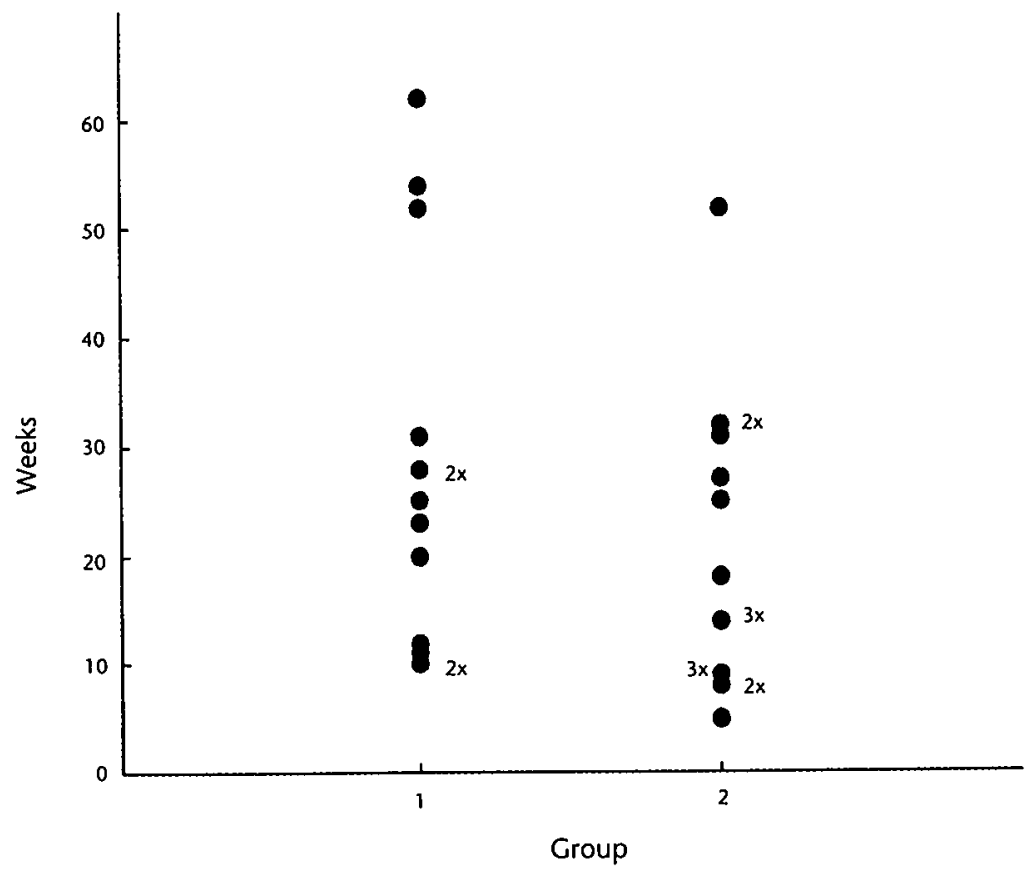

A follow-up time of six weeks was chosen because, if disuse does occur, it is expected to be most pronounced in the first weeks of immobilization ${ }^{25}$. Also, after the first six weeks of a paresis, nerve repair does not occur so quickly that one could expect large differences caused by nerve regeneration in this short measurement period ${ }^{1}$. Patients with a quick recovery in the first weeks after a compression neuropathy were therefore excluded from the study. 


\section{Materials}

\section{Test procedure}

The same test procedure was used in both groups ${ }^{13}$. Isometric torque was measured while the subject was in a supine position with the backrest slightly elevated, the hips slightly flexed and the knee joint in neutral position. The upper and lower leg were fixed to the examination table with two velcro straps. The foot was positioned against a small, horizontally placed, cylindric plastic beam $(17 \times 2 \mathrm{~cm})$ covered with foam rubber, spanning the width of the foot at the level of the first metatarso-phalangeal (MTP 1) joint. To prevent any heel force to exert a moment around the ankle, the foot was not supported below the heel (Figure 2).

\section{Figure 2}

Isometric dorsiflexor strength measurement with the ankle in neutral position $\left(0^{\circ}\right)$ the plastic beam at the level of the MTP joints is connected by a U-shaped hook to a load cell.

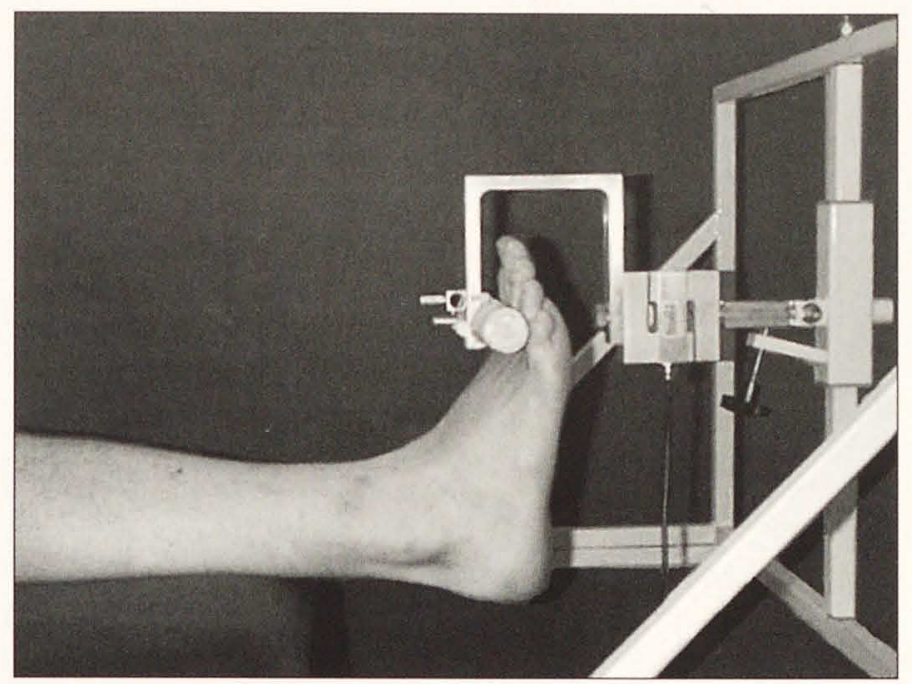

A load cell (model 601) was used to measure force. Data acquisition was performed using a 12 bit DT2824 PGL A/D converter board and MUCAPS software with a sample frequency of $500 \mathrm{~Hz}$ and a sample time of ten seconds. Torque was calculated by using force and force lever data, i.e. the distance between the contact area of the dynamometer with MTP1 and the line connecting the apexes of the lateral and medial malleolus, representing the position of the ankle flexion axis ${ }^{25}$. The centre of the beam was aligned with 
the center of the load cell by a U-shaped, rigid, light-weight hook (Figure 2). Calibration of the dynamometer was performed under static conditions with a known weight after each complete session. Body weight, height and foot length were also measured. Measurements took place in random order in $0^{\circ}$ and $30^{\circ}$ plantar flexion of the ankle with a five minutes pause in between. Subjects repeated the contraction five times with a one minute interval to prevent fatigue. All patients were given standardized verbal instruction to pull the foot against the beam with a maximum effort during five seconds. No verbal encouragement was given. An analog gauge positioned beside the patient gave visual feedback on the relative value of the contraction. At T6, strength of the ankle dorsiflexors healthy leg's was also measured. Reproducibility of this measurement protocol was tested in an earlier study and resulted in a coefficient of variation (CV) of $4.2 \%$ $(\mathrm{SD}=3.6 \%)^{13}$. To assess the intensity of AFO use, we asked patients how many hours of the day they wore the AFO.

\section{Data analysis}

Strength data were analyzed off-line using the MATLAB software package. $A$ one second sustained maximum force effort was calculated from the load cell signal for each trial for each subject by using a windowing technique. To determine the net muscle strength, it is necessary to correct for the effect of the foot's weight ${ }^{26}$, which is estimated to be $1.4 \%$ of the total body weight ${ }^{27}$. The three highest values for each position were selected and the average of these three values was used as the maximum value for the subject in that position, a procedure also used by Heinonen ${ }^{28}$. This process resulted in one torque value, corrected for gravity, for each position, for each subject in each session (TO-T6). Because the present study included both men and women, in a wide range of ages, a large variance existed in absolute strength production. Therefore, the strength value of the affected side was divided by the strength value of the healthy side. This measure is considered the clinically relevant value.

Error analysis: From one patient of the no-AFO group, no measurement of the healthy side was performed. Another patient, enrolled in the no-AFO group, did not show up for the follow-up measurements, though several attempts were made to contact him. This, and the fact that a patient withdrew before T0 after being enrolled in the no-AFO group, explains the difference in groups size. In the TO session, one patient in the no-AFO group failed the strenght test at $30^{\circ}$. One patient in the AFO group omitted to answer the question on hours of daily AFO use. The mean duration of AFO use is therefore reported from fifteen patients. All statistical analyses were performed using SPSS software.

Differences between the groups in severity and duration of the paresis at T0 and of changes in strength production in both positions between TO and T6 were analyzed with the Mann-Whitney $U$ test. The Wilcoxon's matched-pairs signedranks test was used for the within-group analyses between T0 and T6. 


\section{Results}

\section{AFO use}

Patients in the AFO group reported a mean of 8.7 hours $(S D=4.8)$ and a median of 9.7 hours a of daily AFO use.

\section{Strength values}

The mean strength production of the patients' healthy side, compared with those of a reference population in a previous study are presented in Table $\mathbb{1}^{13}$. Patients show $25-50 \%$ lower values in the $30^{\circ}$ position. The mean age within the separate age groups was comparable for the patients and the reference population, except for the category 'women $50-80$ years'.

\section{Table II}

Mean values and SD $(\mathrm{Nm})$ of torque of patients' healthy side compared with a healthy reference population

\begin{tabular}{llllllllll}
\hline & \multicolumn{3}{c}{$30^{\circ}$ ankle position } & \multicolumn{4}{c}{$0^{\circ}$ ankle position } \\
& Patients & $\mathbf{n}$ & Reference & $\mathbf{n}$ & Patients & $\mathbf{n}$ & Reference & $\mathbf{n}$ \\
\hline Male $(20-49 \mathrm{yr})$ & $37.4(12.3) 6$ & $54.4(10.6)$ & 20 & $31.6(11.2)$ & 6 & $41.8(7.0)$ & 20 \\
Male $(50-80 \mathrm{yr})$ & $34.7(10.3)$ & 11 & $44.8(11.7)$ & 13 & $27.2(7.7)$ & 11 & $27.2(11.3)$ & 13 \\
Female $(20-49 \mathrm{yr})$ & $18.9(7.7)$ & 6 & $38.9(6.4)$ & 25 & $14.7(7.9)$ & 6 & $31.2(5.9)$ & 25 \\
Female (50-80 yr) & $21.5(15.3) 2$ & $32.1(8.6)$ & 14 & $12.9(9.1)$ & 2 & $22.3(7.2)$ & 14
\end{tabular}

In Table III maximal strength production values of the paretic side are presented as percentage of the maximum of the healthy side. In this way, patients were compared with their own normal value, so the influence of age or gender on strength production was neutralized. Data were pooled for left or right leg involvement because previous measurements in healthy controls showed no statistical differences ${ }^{13}$.

\section{Table III}

Mean torque $30^{\circ}$ affected side/healthy side (\%)

\begin{tabular}{|c|c|c|c|}
\hline \multicolumn{3}{|c|}{ Measurement session } & \multirow{2}{*}{$\begin{array}{c}\delta \\
\text { T6-T0 }\end{array}$} \\
\hline Group & TO & T6 & \\
\hline 1 No AFO $(n=9)$ & $21 \%(11)$ & $38 \%(20)$ & $17 \%(15)^{\star}$ \\
\hline 2 AFO $(n=15)$ & $24 \%(17)$ & $33 \%(22)$ & $9 \%(12) \dagger$ \\
\hline
\end{tabular}


No significant difference existed between the AFO and no-AFO groups in change of strength production over six weeks.

In Figure 3, the ratio of the torque values of each patient in $30^{\circ}$ ankle flexion at T0 and T6 are set off against the duration of their paresis. No clear pattern is seen for either group, indicating a fair distribution of patients over the two groups.

\section{Figure 3}

Torque ratios at $\mathrm{T} 0$ and $\mathrm{T} 6$ for each patient in each group in $30^{\circ}$ position

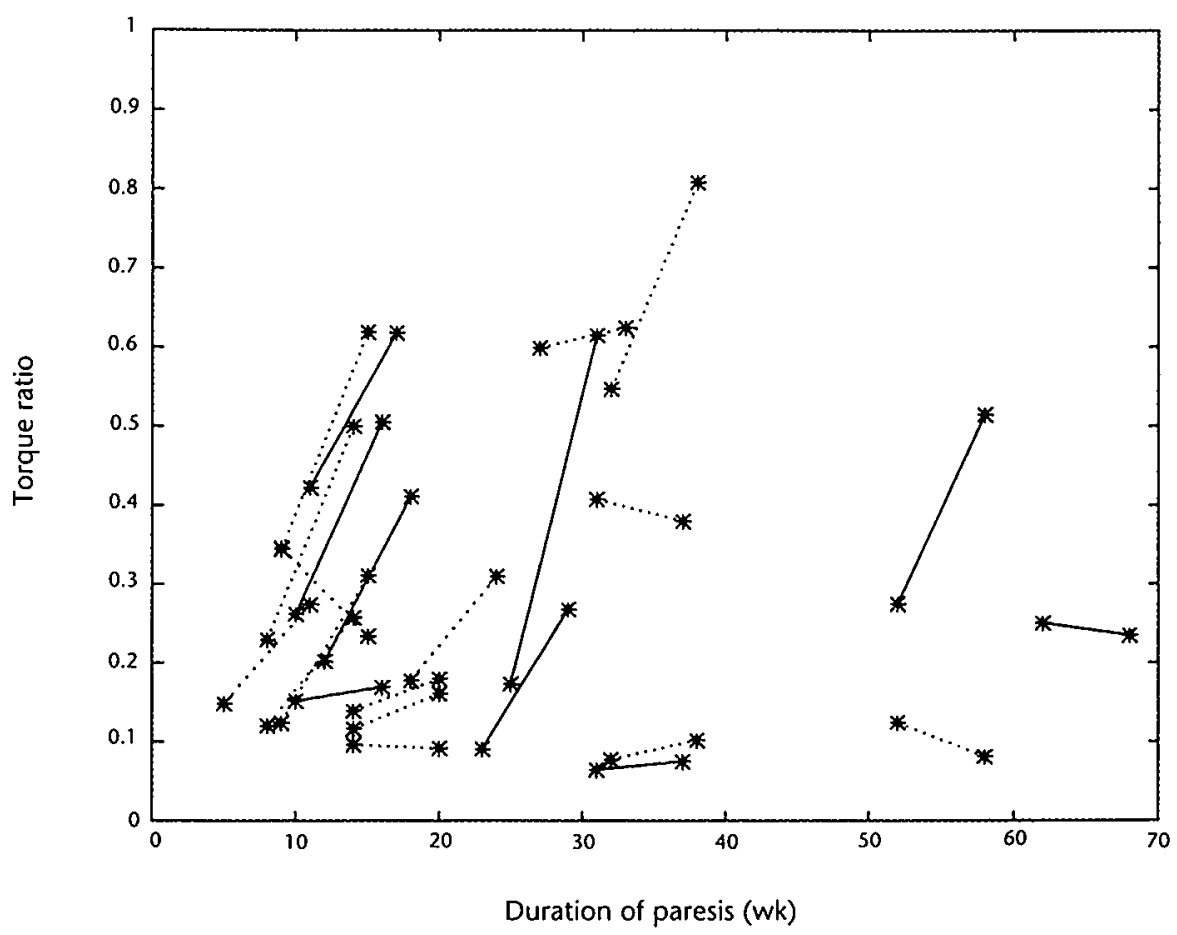

- $=$ no AFO group

$=$ AFO group

The ratio $0^{\circ}: 30^{\circ}$ did not change significantly $(p>0.5)$ for either group between $\mathrm{T} 0$ and $\mathrm{T} 6$, indicating no shift in the optimum of the force - length curve. 


\section{Discussion}

The first question of this study was whether there was difference in restoration of isometric strength production of paretic ankle dorsiflexors between AFO users and a control group. We found a significant progression in torque production in both groups but no significant difference in total relative amount of torque change between the two groups. Thus, in the present study, using an AFO did not influence the restoration of strength in recently paretic patients. This means patients can use an orthosis to improve their walking ability without having to fear negative effects. A disuse effect during the six weeks follow up could have resulted in a maximum loss of strength of $28 \%{ }^{13}$. Given the size of the groups and the standard deviations in strength changes between the patients, and assuming a standard normal distribution, a change of $10-15 \%$ would have produced a significant difference.

The second question posted was whether a difference in changes in strength production with the ankle in $0^{\circ}$ and $30^{\circ}$ plantarflexion could be found. In a previous study on patients whose ankle was immobilized in a plaster cast because of a fracture, no significant differences in the relative amount of strength reduction was found between the two positions ${ }^{13}$. This findings seems to indicate that disuse effects cause strength reduction equally in the two measurement positions, though the ankle was immobilized in $0^{\circ}$. This finding contradicts Baker and Matsumoto ${ }^{29}$ who stressed that the position of immobilization is important to strength reduction. They showed in their rat model a shift of the optimum force length relationship when the muscle was immobilized in a shortened position. In our two groups of paretic patients no significant difference in $0^{\circ}: 30^{\circ}$ ratio could be shown between T0 and T6, indicating no shift in the optimum of the force-length curve.

An isometric strength protocol, of which the reliability and reproducibility was tested previously ${ }^{13}$, was used. Studies focusing on paretic muscles show a good reproducibility for paretic muscles in isometric setting when a well-defined protocol is used ${ }^{30,31}$. The results of the strength measurements in this study therefore seem to be a reliable reflection of the actual changes in strength production of the paretic muscles. When comparing the strength values of the healthy leg of the patients in this study with the healthy reference population in an earlier study ${ }^{13}$, in similar gender and age groups, the overall strength of the healthy side in the patient population was lower. Because the same instrument and protocol were used, this indicates a general decrease of strength of $25-50 \%$ in the patient group, possibly attributable to a lower activity level. Andrews and Bohannon $^{32}$ recently reported the same observation in stroke patients whose strength of the healthy side was also $12-35 \%$ lower compared with healthy subjects.

Patients with paresis from an $L 5$ radiculopathy and from peroneal neuropathy were included in this study, because no different reaction of the 
muscles on the use of an orthosis was expected. Because the first measurement took place at least six weeks after the onset of the paresis, no large changes in nerve function were anticipated during the study time. Nerve lesions caused primarily by demyelination recover quickly in six to eight weeks and thus were not likely to be included in this study. Patients with associated axonal damage can take months to recover. In an L5 lesion from a herniated disk, recovery can take up to one year, with or without surgery $33,34,35,36$. Differences in paresis cause between the two groups are therefore not likely to influence the outcome of the strength measurements.

Patients in the AFO group used the orthosis a mean 8.7 hours daily, with a median of 9.7 hours. Boldingh et al. ${ }^{37}$ reported a median of 10 hours a day in a heterogeneous group of patients. We made no attempt to dictate a minimum time of AFO use because this dictumcannot be controlled and does not reflect the actual use of an AFO in this patient group.

\section{Conclusion}

Using an AFO to correct a foot drop after recent peroneal nerve paresis had no significant effect on restoration of strength. The general decrease of strength values of the healthy side of the patient group compared with the controls may indicate an overall loss of strength caused by less activity. 


\section{References}

1. Katirji B. Peroneal neuropathy. Neurol Clin 1999;17:567-91.

2. Katirji MB, Wilbourn AJ. Common peroneal mononeuropathy: a clinical and electrophysiologic study of 116 lesions. Neurology 1988;38:1723-8.

3. Finkelstein DI, Dooley PC, Luff AR. Recovery of muscle after different periods of denervation and treatments. Muscle \& Nerve 1993;16:769-77.

4. Gordon T, Mao J. Muscle atrophy and procedures for training after spinal cord injury. Physical Therapy 1994;74:50-60.

5. Boonstra AM, van Weerden TW, Strake te L, Hillen B. Ultrasonography of the peroneal nerve muscle group in normal subjects and patients with peroneal paresis. I Clin Ultrasound 1988; 16:17-24.

6. Bramanti P, Santoro A, Santoro G, Trimarchi F, Rizzo G, Pergolizzi S, et al. Denervation muscular atrophy. Studies on the soleus muscle of the albino rat (LM, TEM, Immunofluorescence, image analysis). It / Anat Embryol 1998;103:45-64.

7. McComas A). Human neuromuscular adaptations that accompany changes in activity. Med Sci Sports Exerc 1994;26:1498-1509.

8. Frostick SP. The physiological and metabolic consequences of muscle denervation. Int Angiol 1995; 14:278-87.

9. Duchateau 1, Hainaut K. Electrical and mechanical changes in immobilized human muscle. J Appl. Physiol. 1987;62:2168-73.

10. Appell H]. Muscular atrophy following immobilisation. A review. Sports Med 1990;10:42-58.

11. Berg $H E$, Larsson $L$, Tesch PA. Lower limb skeletal muscle function after 6 weeks of bed rest. I Appl Physiol 1997;82:182-8.

12. Dittmer DK, Teasell R. Complications of immobilization and bed rest. Can Fam Physician 1993;39:1428-37.

13. Geboers JFM, van Tuijl JH, Seelen HAM, Drost MR. Effect of immobilisation on ankle dorsiflexion strength. Scan J Rehab Med 2000;32:66-71.

14. Tropp $H$, Norlin R. Ankle performance after ankle fracture: a randomized study of early mobilization. Foot Ankle Int 1995;16:79-83.

15. Veldhuizen JW, Koene FMM, Oostvogel HJM, van Thiel TPH, Verstappen FT).The effects of a supportive knee brace on leg performance in healthy subjects. Int J Sports Med 1991;12:577-80.

16. Lehmann JF, Condon SM, Lateur BJ de, Price R. Gait abnormalities in peroneal nerve paralysis and their correction by orthoses: a biomechanical study. Arch Phys Med Rehabil 1986;67:380-6

17. Lehmann JF. Push-off and propulsion of the body in normal and abnormal gait, correction by anklefoot orthoses. Clin Orthop 1993;288:97-108.

18. Styf JR, Lundin O, Gershuni DH. Effects of a functional knee brace on leg muscle function. Am / Sports Med 1994;22:830-834.

19. Eisinger DB, Kumar R, Woodrow R. Effect of lumbar orthotics on trunk muscle strength. Am / Phys Med Rehabil 1996;75:194-197.

20. Neumann $H, O^{\prime}$ Shea $P$, Nielson J, Climstein M. A physiological comparison of the short-leg walking cast and an anklefoot orthosis walker following 6 weeks of immobilization. Orthopedics 1989;12:1429-1434. 
21. Rozier CK, Elder JD, Brown M. Prevention of atrophy by isometric exercise of a casted leg. I Sports Med Phys Fitness1979;19:191-194.

22. Germain P, Güell A, Marini JF. Muscle strength during bedrest with and without muscle exercise as a countermeasure. Eur J Appl Physiol 1995;71:342-8.

23. Jones TA, Schallert T. Use-dependent growth of pyramidal neurons after neocortical damage. I Neurosc 1994;14:2140-52.

24. Medical Research Council. Aids to the examination of the peripheral nervous system. Her Majesty's Stationary Office, London;1976.

25. Lundberg A, Svensson OK, Németh G, Selvik G. The axis of rotation of the ankle joint. J Bone Joint Surg 1989;71-B:94-99.

26. Dvir Z. Isokinetic Muscle Testing, Interpretation and Clinical Applications. Singapore: Longman Publishers, 1995.

27. Williams M, Lissner HR. Biomechanics of human motion. WB Saunders, Philadelphia 1962.

28. Heinonen A, Sievanen H, Viitasalo J et al. Reproducibility of computer measurement of maximal isometric strength and electromyography in sedentary middle-aged women. Eur / Appl Physiol 1994;68:310-4.

29. Baker JH, Matsumoto DE. Adaptation of skeletal muscle to immobilization in a shortened position. Muscle \& Nerve 1988;11:231-44.

30. Sapega AA. Muscle performances evaluation in orthopaedic practice. J Bone Joint Surg 1990;72-A:1562-1574.

31. Bohannon RW. Measurement, nature, and implications of skeletal muscle strength in patients with neurological disorders. Clin Biomechanics 1995;10:283-92.

32. Williams Andrews A, Bohannon RW. Distribution of muscle strength impairments following stroke. Clin Rehab 2000;14:79-87.

33. Eysel P, Rompe JD, Hopf C. Prognostic criteria of discogenic paresis. Eur Spine I 1994; 3:214-8.

34. Dauch WA, Fasse A, Brücher K, Bauer BL. Prädiktoren des Behandlungserfolges nach mikrochirurgischer Operation lumbaler Bandscheibenvorfälle. Zentralbl Neurochir 1994;55:144-55.

35. Mohsenipour I, Friessnigg HP, Schmutzhard E. Regressionstendenz neurologischer Defizite nach Nervenwurzelläsionen durch lumbale Diskusherniationen. Zentralbl Neurochir 1993;54:58-65.

36. Von Reichelt A, Grotz M. Lumbaler Bandscheibenvorfall, Ergebnisse der konservativen Behandlung. Fortschr Med 1992;110:275-7.

37. Boldingh EJK, van Pijkeren T, Hermans J. Worden kunststof enkel-voetorthesen gedragen? Ned Tijdschr Geneeskd 1983;127:2280-3. 
Chapter 5 


\section{Chapter 6}

Effects of ankle dorsiflexor paresis and anklefoot orthosis use on walking test performances

JFM Geboers, WLH Wetzelaer, HAM Seelen, F Spaans, MR Drost

in press J Rehabil Med 


\section{Abstract}

The aim of this study was to determine the relation between ankle dorsiflexor strength and performances on several walking tests and to determine the effect of ankle-foot orthosis (=AFO) use on these walking tests. The following tests were used: 10 metre walking test (with and without three stairs), a complex walking task (six-minute walk with cognitive loading) and a subjective evaluation (SIP68 mobility scale and questionnaire). Isometric strength of the ankle dorsiflexors was measured. All walking tests were performed with and without AFO in random order. When relating torque values to walking performances, the highest correlation was found with the ' 10 metre' and '10 metre with stairs' test $(r=-0.51$, i.e. an inverse relationship). No threshold in the degree of paresis was found below which walking disability suddenly increased. No significant improvement could be shown from AFO use on the 10 metre tests. Improvement on the six-minute test was nearly significant $(p=0.06)$, the questionnaire revealed a positive opinion on AFO use related to overall walking function and effort. Thus, we have to conclude that these walking tests do not aid the clinician in estimating the severity of (progression of) the paresis nor to detect differences in degree of paresis between subjects. 


\section{Introduction}

The ICIDH ${ }^{1}$ (International Classification of Impairments, Disabilities and Handicaps) suggests a relationship between an impairment, i.e. loss of a physical function, and a disability, loss of a capacity to perform. Two models, as extremes of a continuum, are suggested in the literature to describe this relation. These are a sliding scale and a threshold model, as illustrated in Figure 1.

\section{Figure 1}

Difference between threshold model and sliding scale model in the relation between torque and function (i.e. walking ability)

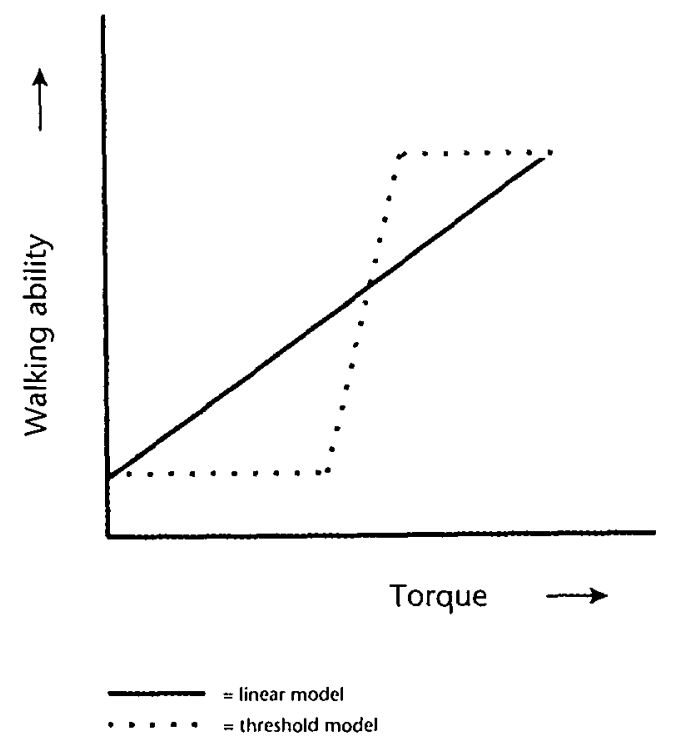

In a sliding scale, a linear relation exists between the degree of impairment and the subsequent disability. A threshold model allows for a certain amount of impairment (i.e. loss of strength) before walking disabilities become evident ${ }^{2}$. The same is true, for example, for loss of vision or cardiac output, before driving or sporting becomes impaired.

Study A tried to identify the nature of this relation for ankle dorsiflexor strength and walking. Walking ability was assessed by the 10 metre walking test, with and without three stairs, the six-minute test with a cognitive task, which was used to mimic a walking situation related to daily function (i.e. walking while focusing attention elsewhere) and the SIP68 mobility scale 3 . 
This scale consists of 12 statements to which a subject can agree or disagree concerning walking in varying circumstances, such as 'I walk shorter distances or stop to rest often.'.

The following questions were posed:

1. Which relation does exist between ankle dorsiflexor strength and the outcome on four walking tests?

2. Which walking test is the most sensitive to strength loss of the dorsiflexors?

Patients with an ankle dorsiflexor paresis often use an ankle-foot orthosis (=AFO) to facilitate walking. Of course, the foot drop is corrected by the orthosis, but it also hinders ankle mobility, adds weight to the leg and is sometimes difficult to accept ${ }^{4}$. Study B was focused on the question whether and in which circumstances the use of an AFO does improve performances of paretic patients on the aforementioned walking tests. All tests were performed with and without AFO in random order. Finally, those patients who used an AFO during six weeks, filled in a questionnaire in which they could indicate whether, in their perception, certain activities had improved by wearing an AFO.

The following questions were posed:

1. To what extent do the scores on the 10 metre walking test, with and without stairs, and the six-minute walking test, immediately improve when an AFO is used?

2. Is there a perceived amelioration of function after six weeks of AFO use?

\section{Methods}

\section{Subjects}

Study A: relation between paresis and walking performances

Thirty-six patients, 27 men and 9 women, participated in this study meeting the following inclusion criteria: age 18 years or older, foot drop MRC 1-4 (strength gradation MRC, for instance $0=$ paralysis, $3=$ against gravity, $5=$ against resistance), caused by a lesion of the peroneal nerve or a $L 5$ radiculopathy, no AFO use and no additional pain, orthopaedic, rheumatologic or neurologic pathology that could interfere with their walking ability. All subjects signed an informed consent. The study was approved by the SRL/iRv medical ethics committee. Patients were recruited from the outpatient clinic from the departments of neurology and rehabilitation from a regional hospital. Measurements took place at a rehabilitation research center.

Study B: effect of AFO use on walking performances

Twenty-seven patients from study A agreed to participate in study $B$. These patients performed both $10 \mathrm{~m}$ tests with and without AFO. Thirteen of them also walked the six-minute minute test with and without AFO. 
A random sixteen of the 36 (randomisation done alternately in the order in which subjects were included) started AFO use after the first measurements. They completed a questionnaire with a subjective evaluation after six weeks.

Table I describes the subjects participating in the experiments. Figure 2 relates the MRC values of the participating subjects to their strength values.

\section{Table I}

Subjects participating in Study A and B

\begin{tabular}{|c|c|c|c|c|}
\hline Study A & Test & $m: f$ & mean age $(y r)$ & duration paresis (wk) \\
\hline$n=36$ & $\begin{array}{l}10 \text { metre test } \\
10 \text { metre test with stairs } \\
\text { SIP68 }\end{array}$ & $27: 9$ & $52(S D=16)$ & $101(S D=183)$ \\
\hline$n=13$ & six-minute test & $12: 1$ & $54(S D=16)$ & $241(S D=14)$ \\
\hline \multicolumn{5}{|l|}{ Study B } \\
\hline$n=27$ & $\begin{array}{l}10 \text { metre test } \\
10 \text { metre test with stairs }\end{array}$ & $20: 7$ & $54(\mathrm{SD}=17)$ & $130(S D=15)$ \\
\hline$n=13$ & six-minute test & $12: 1$ & $54(S D=16)$ & $241(S D=14)$ \\
\hline$n=16$ & Questionnaire & $11: 5$ & $57(\mathrm{SD}=17)$ & $19(S D=15)$ \\
\hline
\end{tabular}

$m: f=$ ratio male $:$ female subjects

$\mathrm{SD}=$ standard deviation of the mean

\section{Figure 2}

Relation between MRC value and torque $(\mathrm{Nm})$ of the ankle dorsiflexors

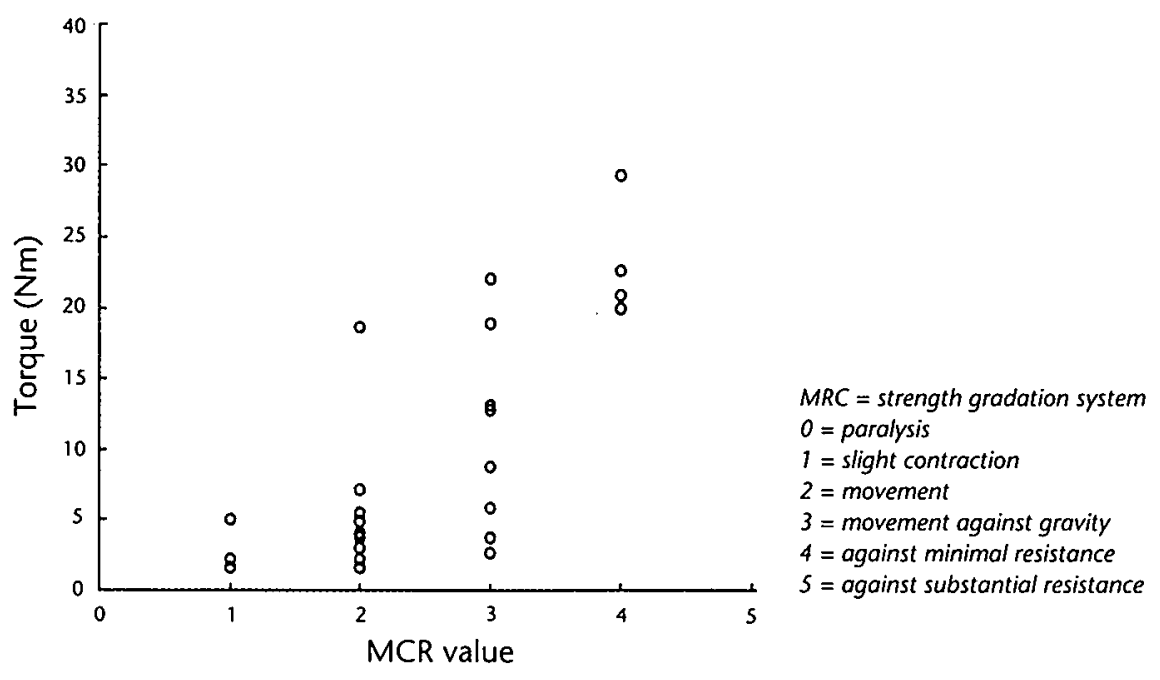




\section{Measurements}

All subjects started with the isometric ankle dorsiflexion torque measurements. Both sides were measured consecutively while the patient was in a supine position with the hips slightly flexed and knees in extension. The foot was positioned against a small horizontally placed bar at the level of the first metatarsophalangeal joint. A load cell (Tedea-Huntleigh model 601 Europe Ltd, Cardiff, UK) was used to measure force. Data acquisition was performed using a 12 bit DT2824 PGL A/D converter board (Data Translation Inc., Marlboro, MA) and MUCAPS software (Multi Channel Acquisition and Processing System, iRv, Hoensbroek, Netherlands) with a sample frequency of $500 \mathrm{~Hz}$ and a sample time of 10 seconds. Torque was calculated using force and force lever data (i.e. the distance between the contact area of the dynamometer with MTP1 and the line connecting the apexes of the lateral and medial malleolus) representing the position of the ankle flexion axis ${ }^{6}$. The centre of the beam was in alignment with the centre of the load cell through the use of an U-shaped rigid light weight hook, as illustrated in Figure 3.

\section{Figure 3}

Torque measurement of the ankle dorsiflexors

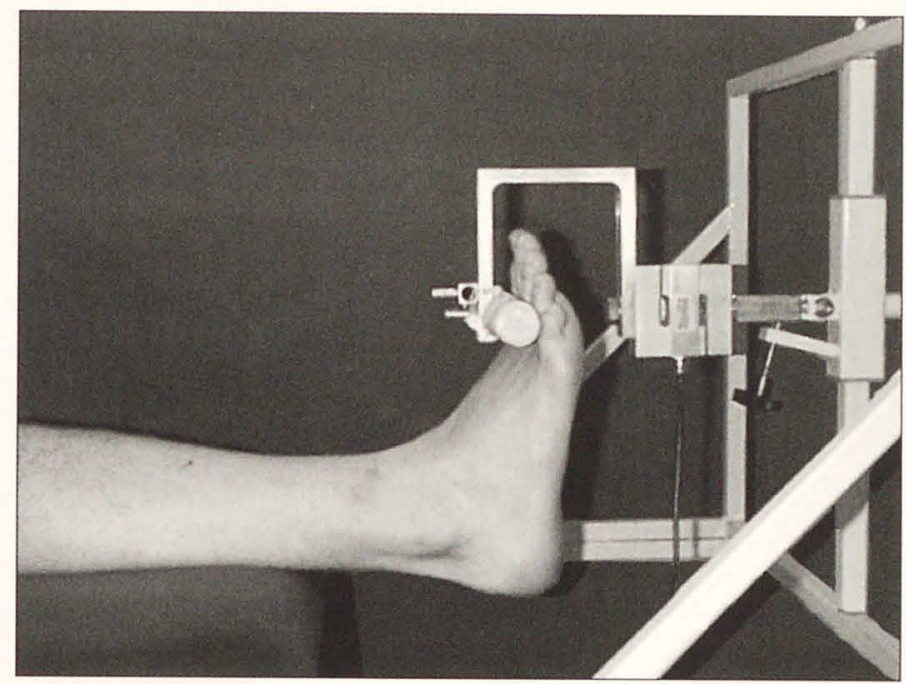

Isometric dorsiflexor torque measurement with the ankle in neutral position $\left(0^{\circ}\right)$ The plastic beam at the level of the metatarsalphalangeal joints is connected by $a$ U-shaped hook to a load cell.

After each complete session, calibration of the dynamometer was performed under static conditions with a known weight. Body weight, height 
and footsize were also measured. Measurements took place in $30^{\circ}$ plantar flexion of the ankle. Subjects repeated the contraction five times with a one minute interval to prevent fatigue. All patients were given standardised verbal instruction to pull the foot against the beam with a maximum effort during five seconds. No verbal encouragement was given. An analogue gauge positioned next to the patient gave visual feedback on the relative strength of the contraction. Reproducibility of this measurement protocol was tested in an earlier study and resulted in a coefficient of variation $(\mathrm{CV})$ of $4.2 \%(\mathrm{SD}=3.6)^{7}$.

Three walking tests were performed and a questionnaire was filled out afterwards. First, walking ability was measured by asking the patient to walk 10 metres at maximum safe walking speed while time was recorded by a stopwatch. Patients started from a standing position. Use of a walking aid was allowed during the test, but only 2 people used a crane or crutch. The test was performed with and without an AFO, at random order. A standard AFO was used. Secondly, the 10 metre walking test was modified by adding a three steps stair in the middle of the track. The protocol was identical to the first 10 metre test. After a break of 10 minutes, patients were asked to walk six minutes at maximum walking speed while subtracting 7 from 1000 without verbal encouragement. The walking distance was registered at five metre intervals every two minutes and could be read from signs which where placed at the wall every five metres along an indoor, flat surface track. The test was performed twice, i.e. at random with and without an AFO. Both tests were interspaced by a resting period of 15 minutes. In this time patients filled out the mobility scale of the SIP68.

Sixteen patients started AFO use after this measurement session and completed a questionnaire with subjective evaluation of AFO use after six weeks.

\section{Data analysis}

Strength data were analysed off-line using the MATLAB software package (The Math Works Inc., Natick, MA). A one second sustained maximum force effort was calculated from the load cell signal for each trial for each subject using a windowing technique. In order to determine the net muscle strength it is necessary to correct for the effect of the weight of the foot ${ }^{8}$, which is estimated at $1.4 \%$ of the total body weight ${ }^{9}$. The three highest torque values were selected and the average of these three values was used as the maximum value for the subject, a procedure also used by Heinonen et al. ${ }^{10}$. This process resulted in one mean torque value, corrected for gravity, for each subject.

Outcome of the 10 metre walking test and the 10 metre walking test with stairs was given in seconds. Results of the six-minute walking test were expressed in metres walking distance.

The relation between the strength values and walking tests outcome was expressed by the Pearson correlation coefficient. The percentage of variance in 
walking test results that could be explained by the strength parameter was also given. An iterative process involving a linear fitting of the data using incremental numbers of data points of the total data set was done, in search of a clear cut off point below which a sharp decline in function occurred.

The Wilcoxon signed rank test was used to determine the amount of change in walking test performances induced by AFO use. All statistical analyses were done with SPSS (SPSS Inc., Chicago, IL).

\section{Results}

Study A: relation between degree of paresis and walking performances

The relation between torque and the performances on the walking tests are given in Figure 4. A second order curve is fitted through the data.

\section{Figure 4}

Relation between torque of the ankle dorsiflexors and walking test performances
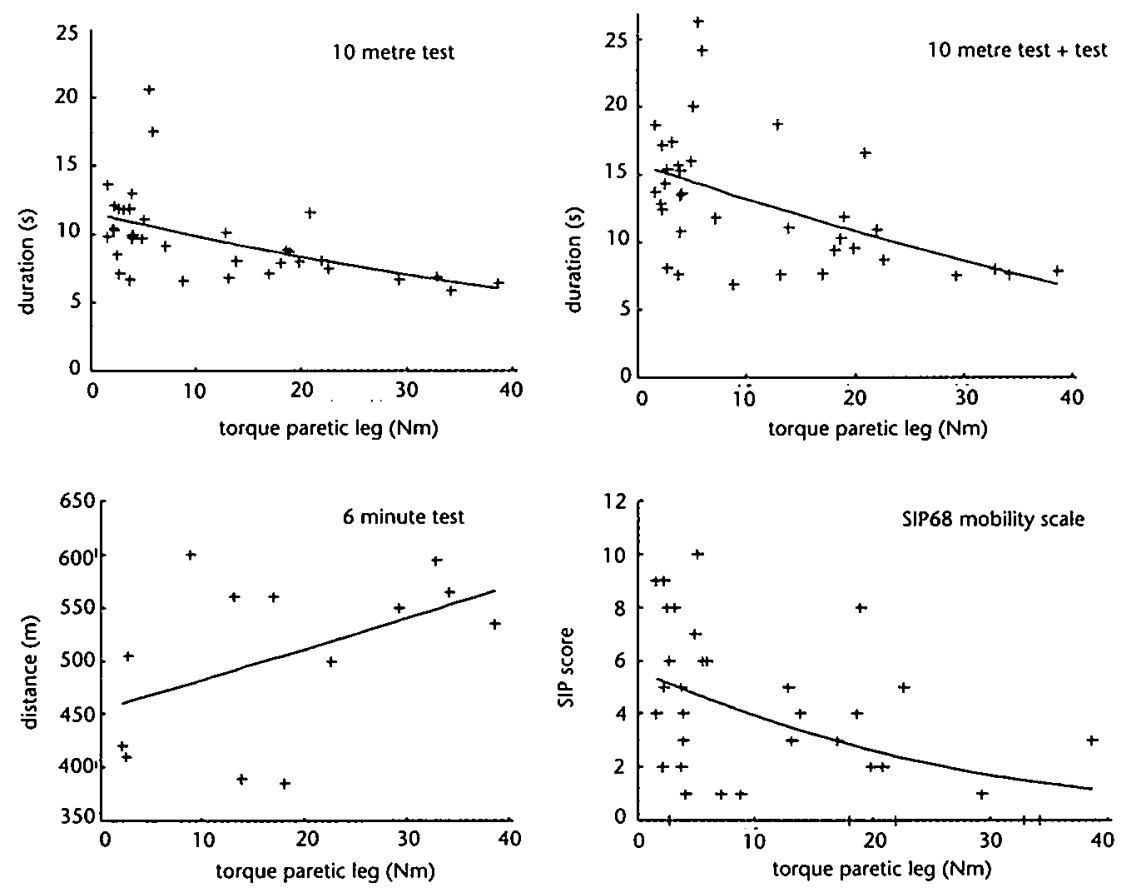

A second order curve is fitted: 
No threshold, i.e. a sharp distinct transition between the slopes of the consecutive lines during the incremental linear fitting, could be identified for either of the four tests. The Pearson correlation coefficient, indicating the degree to which there is a linear relation between the variables, varied between 0.46 and -0.51 . The subsequent amount of variance explained by the degree of the paresis ranged from $21 \%$ to $26 \%$ (Table II).

\section{Table II}

Correlation between torque and scores on the walking tests

\begin{tabular}{lcccc}
\hline & $10 \mathrm{~m}$ & $10 \mathrm{~m}+$ & $6 \mathrm{~min}$ & \multicolumn{1}{c}{ SIP68 } \\
\hline Pearson's $r$ & -0.51 & -0.51 & 0.46 & -0.45 \\
variance explained & $26 \%$ & $26 \%$ & $22 \%$ & $21 \%$ \\
\hline
\end{tabular}

Study B: effect of AFO use on walking performances

Figure 5 shows the effect of AFO use on the tree walking tests.

\section{Figure 5}

Differences in walking scores between ankle-foot orthosis (=AFO) and no-AFO use (score on test with AFO minus score on test without AFO) for A: 10 metre test, B: 10 metre with stairs, C: 6 minute walk

A

10 metre test

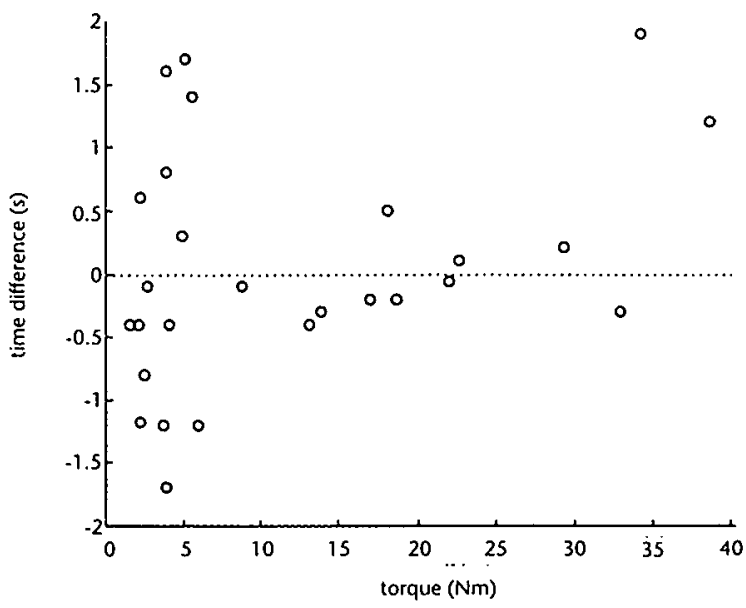



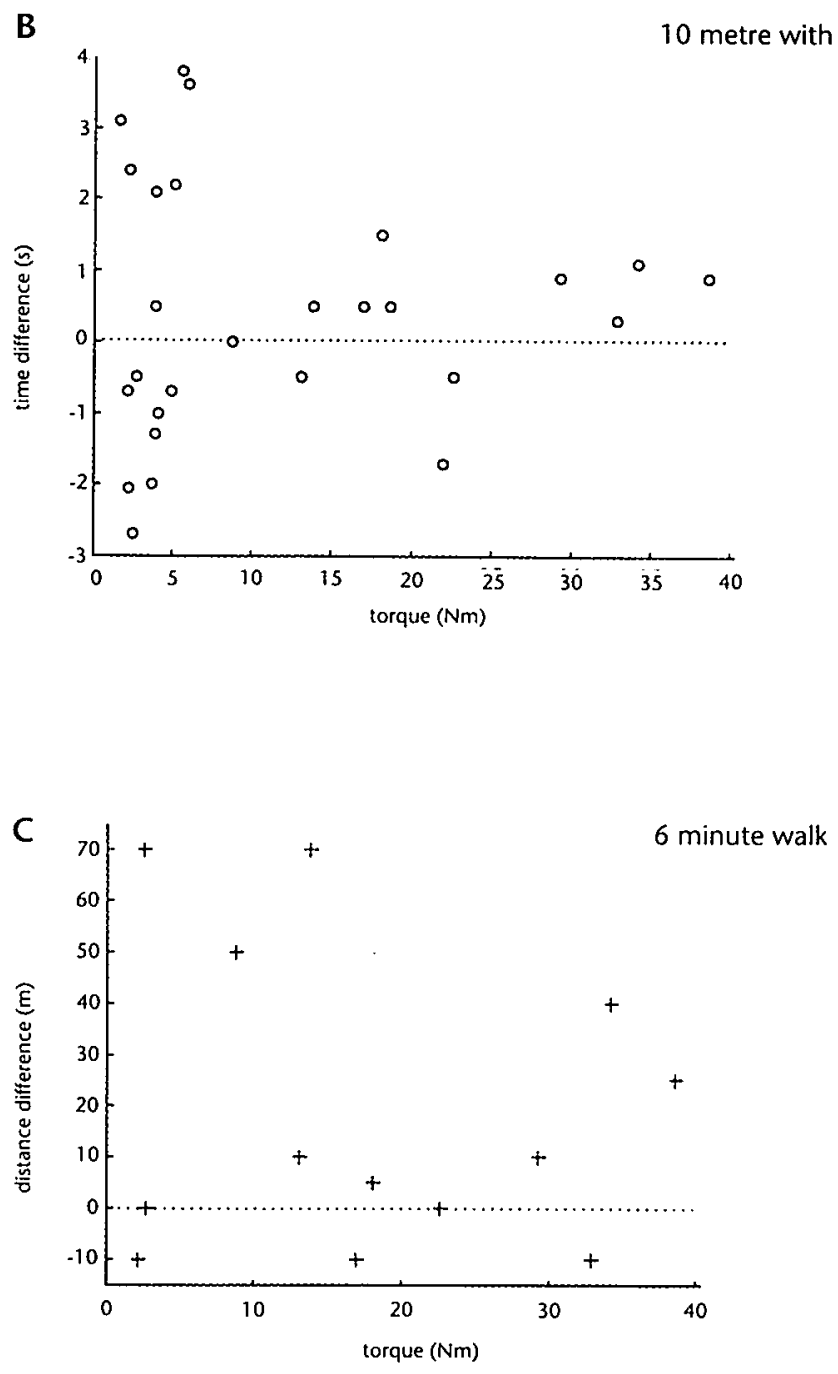

There was no significant improvement on either test with AFO use, p-values of 0.88 and 0.37 respectively for the 10 metre test and the 10 metre with stairs test. The six-minute test had a p-value of 0.06 with only 13 subjects, indicating a tendency to an improved performance with AFO use. 
The subjective evaluation of sixteen patients after six weeks of AFO use, indicated a positive result on walking performance and walking effort in $75 \%$ of all cases. No subjective improvement was reported on walking stairs or walking speed. Squatting with an AFO was reported difficult.

\section{Discussion}

Relation between ankle dorsiflexion strength and walking test performances

The results on the walking tests reflect a large inter-individual variety, especially in those subjects with a low strength value. In these subjects, very large differences in test results are seen, some results even comparable to those of normal strength values. The distance walked in the six-minute walking test ( 525 metres $(S D=76)$ ) by our paretic subjects was comparable with that of healthy subjects $\left(631(\mathrm{SD}=93)^{11}\right.$ and 535 metres $\left.^{12}\right)$.

A clear cut off point in torque value below which walking difficulties occurred could not be demonstrated, either on the walking tests, or on the SIP68 mobility scale measuring perceived walking comfort. We could demonstrate neither a linear nor threshold model in our data. Other researchers in the rehabilitation field however did describe these models. An example of the threshold model is found in Stam \& Binkhorst ${ }^{13}$ who described this effect in Guillain-Barré patients. All patients had good functional scores with strength levels of $80 \%$ or more of their normal strength, and very bad test scores below $20 \%$ of their normal strength. Between 20 and $80 \%$ of normal strength values, scores on functional tests differed largely, possibly indicating differences in compensation abilities. Rantanen et al. ${ }^{14}$ found poor walking ability in older women with a knee extension torque of less than $1.1 \mathrm{Nm} / \mathrm{kg}$, above this strength, gradual improvement in walking occurred up to a threshold of $2.3 \mathrm{Nm} / \mathrm{kg}$ above which no increase of walking speed was gained by more strength.

A sliding scale is described by Salsich \& Mueller ${ }^{15}$ for example, who found a strong $(r=0.69)$ correlation between hip extension strength and walking speed in diabetic patients with a transmetatarsal amputation. Rantanen et al. ${ }^{16}$ also found a significant $(p<0.001)$ association between knee extension torque and maximum walking speed and climbing stairs in older subjects.

In this study, the highest (inverse) correlation ( $r=-0.51)$ was found with both the 10 metre tests. Adding stairs in the 10 metre distance did not change the test's sensitivity. Torque of the dorsiflexors explained thus only $26 \%$ of the variance of the test results. Lankhorst et al. ${ }^{17}$ also found that strength of the knee muscles could only explain $25-35 \%$ of the variance in walking tests of patients with gonarthrosis. 


\section{Clinical implications}

It remained unclear, why some patients with a mild paresis reported a lot of problems in daily life, whereas others, with a more severe paresis perceived only few problems. Apparently, other factors play an important role, for example an increase of attention focused on the task, visual control, a slower walking speed, compensation from other muscles, movement skill or overall condition ${ }^{18}$. Geurts et al. ${ }^{19}$ demonstrated that in patients with a prosthesis after a recent amputation, concentration was highly focused on maintaining balance, especially in the first weeks of rehabilitation. The accumulated effect of these different compensation facilities can probably account for the large inter-individual variety, especially between patients with comparable low torque values.

Due to this large inter-individual variety, and the fact that no threshold was found, these tests can not be used for early detection of the development of functional problems, for example in patients with a (progressive) paresis. For this purpose, a decrease in functional test scores should precede an imminent decline in daily functioning as Guralnik et al. ${ }^{20}$ demonstrated in the relation between scores on walking tests and subsequent disability after four years follow-up in elderly persons.

Thus, we have to conclude that these walking tests do not aid the clinician in estimating (progression of) the severity of the paresis nor to detect differences in degree of paresis between subjects.

\section{Effect of AFO use on walking tests performances}

In subjects with a dorsiflexor paresis, an AFO of course assists to correct the foot drop, thus preventing stumbling. No significant improvement on the 10 metre tests was found. The six-minute test with cognitive task, which was added to mimic a functional situation, tended to show a significant improvement on AFO use, even with the rather small number of 13 subjects. Thus, walking problems induced by fatigue might be helped by AFO use. However evaluation in a larger group will be necessary to be able to significantly demonstrate this. Subjective evaluation was also positive for walking performance and walking effort.

A comparable result, i.e. a lack of significant improvement on SIP scores or walking speed, was reported by Beckerman et al. ${ }^{21}$ in evaluating the influence of tibial nerve block and AFO use on walking ability of stroke patients. 


\section{Conclusion}

Walking is a highly automated activity. It is often combined with other tasks on which attention is focused, such as talking, watching or working 22 . However, when a failure in the neuromotor system is present, this automatism is impaired. Restoration of walking after central or peripheral neurological damage, is an often encountered task in rehabilitation medicine. A patient, being able to set a few steps in a therapeutic setting, still has a long way to go to regain walking ability as an automated function on which he can rely while performing other tasks. Orthosis are often prescribed during this process of regaining walking ability.

For subjects with a dorsiflexor paresis, we concluded that an AFO does not support walking performances as measured by the 10 metre tests, and might support walking in longer distances ( 6 minute test). The subjective evaluation by the questionnaire revealed a predominantly positive result on perceived walking effort and walking performance, and most physiatrists and therapists will argue they experience positive results in numerous patients.

Thus, even in this simple diagnosis, i.e. peripheral paresis of the dorsiflexors, it turns out to be difficult to precisely formulate when and in which circumstances a paresis results in walking problems, and which function, associated with walking, is best helped by AFO use. 


\section{References}

1. International Classification of Impairments, Disabilities and Handicaps classification relating to the consequences of disease, 1980.

2. Fried LP, Herdman SI, Kuhn KE, Rubin G, Turano K. Preclinical disability: hypotheses about the bottom of the iceberg. J Aging Health 1991;3:285-300.

3. Post MWM, Bruin AF de, Witte LP de, Schrijvers AIP. The SIP68: a measure of healthrelated functional status in rehabilitation medicine. Arch Phys Med Rehabil 1996; 77:440-445.

4. Fisher LR, McLellan DL. Questionnaire assessment of patient satisfaction with lower limb orthoses from a district hospital. Prosth Orth Int 1989;13:29-35.

5. Medical Research Council. Aids to the examination of the peripheral nervous system. Her Majesty's Stationary Office, London, 1976.

6. Lundberg A, Svensson OK, Németh $G$, Selvik $G$. The axis of rotation of the ankle joint. J Bone Joint Surg 1989;71-B:94-99.

7. Geboers JFM, van Tuij JH, Seelen HAM, Drost MR. Effect of immobilization on ankle dorsiflexion strength. Scand J Rehabil Med 2000;32:66-71.

8. Dvir Z. Isokinetic Muscle Testing, Interpretation and Clinical Applications. Singapore: Longman Publishers, 1995.

9. Williams M, Lissner HR. Biomechanics of human motion. WB Saunders, Philadelphia 1962.

10. Heinonen A, Sievänen H, Viitasalo J, Pasanen M, Oja P, Vuori I. Reproducibility of computer measurement of maximal isometric strength and electromyography in sedentary middle-aged women. Eur J Appl Physiol Occup Physiol 1994;68:310-314.

11. Troosters T, Gosselink R. Decramer M. Six minute walking distance in healthy elderly subjects. Eur Respir J 1999;14:270-274.

12. Enright $P L$, Sherrill $D L$. Reference equations for the six-minute walk in healthy adults. Am J Respir Crit Care Med 1998;158:3184-3187.

13. Stam H, Binkhorst R. Muscle strength impairment and disability in Guillain-Barré patients: a pilot study. I Rehabilitation Science 1989;2:108-110.

14. Rantanen T, Guralnik JM, Izmirlian G, Williamson JD, Simonsick EM, Ferrucci L, Fried LP. Association of muscle strength with maximum walking speed in disabled older women. Am J Phys Med Rehabil 1998;77:299-305.

15. Salsich GB, Mueller MJ. Relationship between measures of function, strength and walking speed in patients with diabetes and transmetatarsal amputation. Clin Rehabil 1997;11:60-67.

16. Rantanen T, Era P, Heikkinen E. Maximal isometric strength and mobility among 75-year-old man and women. Age Ageing 1994;23:132-137.

17. Lankhorst GI, van de Stadt RI, van der Korst JK. The relationships of functional capacity, pain, and isometric and isokinetic torque in osteoarthrosis of the knee. Scand I Rehabil Med 1985; 17:167-172.

18. Mulder T, Geurts A. Recovery of motor skill following nervous system disorders: a behavioural emphasis. Baillière's Clin Neur 1993;2:1-13.

19. Geurts A, Mulder T, Nienhuis B, Rijken R. Dual-task assessment of reorganization of postural control in persons with lower limb amputation. Arch Phys Med Rehabil $1991 ; 72: 1059-1064$. 
20. Guralnik JM, Ferrucci L, Simonsick EM, Salive ME, Wallace RB. Lower-extremity function in persons over the age of 70 years as a predictor of subsequent disability. $N$ Engl J Med 1995;332:556-561.

21. Beckerman $H$, Becher I, Lankhorst G], Verbeek AL. Walking ability of stroke patients: efficacy of tibial nerve blocking and a polypropylene ankle-foot orthosis. Arch Phys Med Rehabil 1996:77;1144-1151.

22. Mulder T, Nienhuis B, Pauwels J. Clinical gait analysis in a rehabilitation context: some controversial issues. Clin Rehab 1998;12:99-106. 
Chapter 6 
Chapter 7

General Discussion 


\subsection{Main questions}

The present study was performed to gain insight in the effects of orthoses on paretic muscle activity and strength. We studied the effects of an ankle-foot orthosis (=AFO) in patients with a paresis of the ankle dorsiflexors due to damage to the peripheral nerve or nerve root, existing between six weeks and 1 year. We have focused upon this type of paresis because it frequently occurs, the function of the muscles involved is unambiguous and the muscles are easily accessible to investigation. The effects of AFO use on impairment level, i.e. strength and muscle activity, were measured and it was determined whether adaptation of muscle activity to AFO use occurred during six weeks follow-up. At the disability level, the relation between the amount of strength loss and the occurrence of walking problems was studied. It was evaluated whether a sharp decrease in walking performance occurred below a certain level of residual strength (threshold theory). Whether AFO use leads to improved walking was evaluated during specific walking tasks.

\subsection{1}

Our first question was whether the ankle dorsiflexors are susceptible to strength loss due to immobilization at all. After all, disuse studies show large differences between different muscles in their reaction to forced rest. As described in Chapter 3, we found the ankle dorsiflexors to be highly susceptible to strength loss. After 40 days of immobilization of the ankle in a weight bearing plaster cast, because of a lower leg fracture in otherwise healthy subjects, strength decreased $28 \%$, irrespective of age and gender. This was in accordance with earlier findings by Tropp et al. ${ }^{1}$. After cast removal full strength recovery took place within a period of six weeks without specific therapy. This amount of strength decrease proved these muscles can suffer negative side effects due to immobilization, probably even if this immobilization is partial as is the case in AFO use. The question whether restoration of strength after cessation of AFO use would also occur in the paretic muscles remains to be answered.

\subsection{2}

Subsequently, we posed the question whether, and if so, to what extent and during which part of the step cycle, the dorsiflexor muscles were less active while supported by an AFO. Muscle activity was recorded using surface EMG. Our results, described in Chapter 4, indicate that both healthy and paretic muscles immediately react to AFO use with a significant decrease in activity, i.e. $20 \%$ and $7 \%$, respectively. In healthy muscles this decrease is seen immediately after heel strike. In paretic muscles, the TA activity during the whole step cycle decreased when an AFO was used. This means that, although muscle activity is less during orthosis use, there is no distinct on-off situation, contrary to common belief. The reproducibility of the EMG patterns of the lower leg muscles was evaluated in healthy volunteers. The reported 
correlation coefficient for the within-subject reproducibility proved to be good for most muscles measured, i.e. varying between 0.68 and 0.96 (mean 0.86). This finding is in accordance with results reported by Winter et al. ${ }^{2}$. For the analysis of the within-group differences, variety in walking velocity between the subjects was not considered a relevant variable in the explanation of data, because the walking velocity within persons on the different measurements was nearly identical. Earlier studies of McCulloch et al. ${ }^{3}$ and Yang et al. ${ }^{4}$ showed no significant changes in EMG patterns in subjects while walking (not running) at different speeds. Moreover, because relative changes were used to compare between subjects, no significant influence of walking speed was expected.

\subsection{3}

In order to answer the question whether possible adaptation effects occur due to prolonged AFO use during six weeks, twenty-nine patients with a fairly recent paresis were randomly assigned to either a group with or a group without AFO use. Dissimilarities in aetiology of the paresis (i.e. radiculopathy or peripheral nerve lesion) were not taken into account because no difference was expected in the muscle reaction on AFO use between the two diagnostic groups. There were no significant differences between the two patient groups in either duration or severity of the paresis. The percentage of immediate decrease in muscle activity after putting on an AFO was stable during six weeks follow-up as was the absolute amount of muscle activity. This suggests that no obvious central adaptation took place. If it had been the case, we would have expected a decrease of muscle activity in those subjects who were used to wearing an AFO, when their muscle activity was recorded during walking without AFO. In that case, the difference in EMG activity between the two conditions, with or without AFO, measured at 0 and 6 weeks, would have become less. This result appears to be in contrast to recent literature concerning adaptation of the nervous system, which suggests a quick adaptation in case of reduced proprioceptive input and decreased activity level of a limb $b^{5-10}$. In the present study, the relatively minor, although significant, amount of decrease in muscle activity did not seem to generate a quantifiable adaptation to a lower muscle activity level while walking without an AFO. Muscle activity remained higher without AFO, even in the group of patients who became accustomed to daily AFO use.

\subsection{4}

Furthermore, assuming AFO use leads to a consistent, small but significant decrease in muscle activity, but does not result in inactivity of the supported muscles, the question whether this reduction in muscle activity would hinder strength recovery was posed. Isometric strength was measured in $0^{\circ}$ and $30^{\circ}$ plantar flexion. As expected, reference values, measured in healthy volunteers, showed significant age and gender dependent differences in torque 
production, and are reported in Chapter 5 . No significant differences were found between the left and right leg or in relation to leg dominance. The protocol resulted in reproducible values. In the patient group, all participants, both AFO users and non-AFO users, gained strength significantly during the six weeks follow-up period, i.e. $9 \%(S D=12)$ and $17 \%(S D=15)$, respectively. On an individual level, in both groups subjects with upward and subjects with downward changes in strength were present, as is illustrated in Figure 3 in Chapter 5. This was in contrast to the study in healthy subjects reported in Chapter 3, who showed a fairly consistent recovery pattern.

\subsection{5}

Finally, we studied whether the AFO did actually improve walking, and, if so, whether the effect was more pronounced below a certain level of strength loss (threshold theory) and/or during specific activities. In Chapter 6 the results of the evaluation of the effects of AFO use on walking tests are described. The results of the walking tests reflected a large inter-individual variety as was also seen in the strength and EMG data, especially in those subjects with low strength values. In these subjects, large differences in test scores were observed, sometimes with results comparable to healthy subjects. The mean distance covered in the six-minute walking test by our subjects with a paresis, for example, was similar to that of healthy subjects ${ }^{11}$. The possible consequences of this variability are discussed in the next section (7.2.1). The walking tests used could not provide a clear threshold in the relation between strength reduction and the occurrence of walking difficulties. The highest (inverse) correlation was found in both the 10 metre walking tests. Adding stairs in the 10 metre distance did not change the test's sensitivity. Torque of the dorsiflexors explained only $26 \%$ of the variance of the test results. This is in agreement with clinical observations, in which patients with a moderate to severe paresis sometimes report little or no difficulties in daily live, while others, with an objectively less severe paresis, complain of stumbling and other walking problems. Also other studies, focusing on the relation between strength and disability, showed only a low correlation ${ }^{12-14}$. Only the subjective evaluation in our study showed a positive result of AFO use. Tyson \& Thornton ${ }^{15}$ recently evaluated the use of a hinged ankle-foot orthosis in stroke patients and found a small improvement on the scores of the Functional Ambulation Category, but a more positive result in the subjective evaluation. Beckerman et al. ${ }^{16}$ reported no significant improvement on AFO use in stroke patients, either on the 10 metre test, or on the SIP questionnaire. 


\subsection{6}

\section{Primary conclusion}

The general answer to our main question, i.e. does AFO use counteract muscle activity and strength restoration in patients with a recent foot drop, is: 'No, it does not'. It is safe to use an AFO when necessary. Subjectively, most AFO users reported an improvement on walking performance and experienced less physical effort. However, we could not demonstrate a positive effect of AFO use on the walking tests used.

\subsection{Additional findings}

The present study also provided some additional findings which are discussed below.

\subsection{1}

\section{Specificity of paretic muscle reactions}

Most research in the field of gait analysis and orthosis use is done in (neurological) healthy young volunteers and is performed without follow-up measurements to search for adaptation effects. They give ample information on changes in specific gait parameters, yet without giving an indication as to possible consequences of these changes for the patient in terms of walking distance, walking during daily activities or possible negative effects $3,17,18$. An important additional observation during our EMG and torque measurements concerned the large inter-individual differences in the patient population compared to the healthy subject population. For example, the EMG patterns of the different muscles during one step cycle in the paretic subjects were very heterogeneous, the reason for which the decrease of TA activity during AFO use in this group was measured over the whole step cycle instead of over the first $10 \%$ of the step cycle as in the healthy subjects. These observations underline that results obtained from a healthy population can not be extrapolated to patients.

\subsection{2}

\section{Estimation of severity of paresis}

As the healthy side is commonly used for collecting reference values during clinical examination we want to draw attention to the lower strength of the healthy leg of the patient group with a peripheral paresis that was found compared to the reference group. In contrast, strength of the healthy leg in the patients with a lower leg fracture, discussed in chapter 3 , was not different from the reference group. Because the same instrument and protocol was used, and patients with a polyneuropathy were excluded from this study, this suggests a general decrease of strength of $25-50 \%$ of the healthy leg in the paretic patient group. Andrews ${ }^{19}$ reported a comparable observation in very recent stroke patients whose strength of the healthy side was $12-35 \%$ lower 
compared to healthy subjects. Apparently, this phenomenon will interfere with the estimation of the severity of paresis. Whether an explanation must be sought in a global reduction of physical activities or in a reduction of central nervous drive is not clear. Evidence as to the latter comes from a study into dexterity (finger tapping) in recent stroke patients ${ }^{20}$ showing a decrease of this skill in both sides, suggesting a central origin of this decrease in function of the non-paretic side. To what extent and how quick contralateral reduction of strength and skill is seen in other, peripheral nerve disorders remains unclear and will need further investigation.

\subsection{3}

\section{Walking tests}

The use of walking tests and questionnaires in our study did not provide additional information to the simple question 'do you feel the use of an AFO improves your walking ability?'. Although the tests ( $10 \mathrm{~m}$ test and $6 \mathrm{~min}$ test) and the questionnaire (SIP68 mobility scale) used are well known for their reliability, they did not add information to the question how and when an AFO influences walking ability, yet it was reported by the patients that it did. Obviously, these tests were not able, or not specific enough, to detect the subjectively improved walking ability.

\subsection{4}

\section{Relation Impairment Disability}

Treatment in rehabilitation medicine is classically aimed at three levels, the impairment, disability and handicap level. Much research is aimed at the disability level, focusing on items like independence in bathing, dressing and walking. In this study a commonly accepted aid on disability level, i.e. an AFO, was evaluated on its effect not only regarding this disability level (i.e. walking) but also regarding the impairment level (i.e. muscle activity and strength). We concluded that the effect of an orthosis on the patient's ability to walk is not predominantly related to the severity of the paresis, but seems mainly dependent on the compensation mechanisms the patient is able to use. Compensation may become apparent in a different walking pattern, a slower tempo, more concentration etc.. The walking tests used did not specifically test the mental effort needed to walk safely, nor the frequency of stumbling, nor the increased hip flexion needed to compensate for the loss of ankle dorsiflexion. The six-minute test with cognitive load was specifically expected to be sensitive to attention effects needed in walking, but this could not be demonstrated. Recent studies ${ }^{21,22}$ give conflicting evidence as to the cognitive load associated with walking. Haggard et al. ${ }^{21}$ in a neurological rehabilitation population found a significant decrease in walking velocity in dual task circumstances, suggesting concentration was needed for walking. Ruchinskas et al. ${ }^{22}$, in a geriatric population found that even with severe cognitive deficits, walking remained possible. An explanation might be, 
that the neurological impaired subjects had to learn to walk in new circumstances while the geriatric population relied on old patterns. This was also demonstrated in the study of Geurts et al. ${ }^{23}$ in subjects with a recent amputation at the start of their rehabilitation who needed more cognitive control to remain stable while standing upright. At the completion of their rehabilitation period, the cognitive burden was less and automation of the motor pattern had obviously taken place. The same mechanism might explain why we did not find a difference in the six-minute test. In this transversal part of our study, also subjects with a long-standing paresis of the ankle dorsiflexors participated. These subjects probably had already achieved a new walking automatism, and were therefore less sensitive to dual task interference. However, our group was too small to be able to compare the results of subjects with a relative recent paresis to those with a long-standing paresis.

\subsection{Future research}

In our study, the paresis could only explain up to $26 \%$ of the walking difficulties occurring in the 10 metre walking tests without AFO. Apparently, other, more important factors are responsible for the walking ability. This was also reflected in the large inter-individual differences in walking test results in patients with severe strength loss. Future research, therefore, should be directed to understanding the different compensation mechanisms and methods necessary to optimise relearning of motor processes and the use of these compensation mechanisms in neurological impaired persons. 


\section{References}

1. Tropp $H$, Norlin R. Ankle performance after ankle fracture: a randomized study of early mobilization. Foot Ankle Int 1995;16:79-83.

2. Winter DA, Yack HJ. EMG profiles during normal human walking: stride-to-stride and inter-subject variability. Electroencephalogr Clin Neurophysiol 1987;67:402-11.

3. McCulloch MU, Brunt D, Vander Linden D. The effect of foot orthotics and gait velocity on lower limb kinematics and temporal events of stance. I Orthop Sports Phys Ther 1993;17:2-10.

4. Yang JF, Winter DA. Surface EMG profiles during different walking cadences in humans. Electroencephalogr Clin Neurophysiol 1985;60:485-91.

5. Bruehlmeier M, Dietz V, Leenders KL, Roelcke U, Missimer J, Curt A. How does the human brain deal with a spinal cord injury? Eur J Neurosci 1998;10:3918-22.

6. Cohen LG, Roth B], Wassermann EM, Topka H, Fuhr P, Schultz I, et al. Magnetic stimulation of the human cerebral cortex, an indicator of reorganization in motor pathways in certain pathological conditions. I Clin Neurophysiol 1991;8:56-65.

7. Green JB, Sora E, Bialy Y, Ricamato A, Thatcher RW. Cortical sensorimotor reorganization after spinal cord injury: an electroencephalographic study. Neurology 1998;50:1115-21.

8. Hallett M. The plastic brain. Ann Neurol 1995;38:4-5.

9. Liepert J, Weiller C. Mapping plastic brain changes after acute lesions. Curr Opin Neurol 1999;12:709-13.

10. Pachter BR, Eberstein A. Neuromuscular plasticity following limb immobilization. ) Neurocytol 1984;13:1013-25.

11. Enright PL, Sherrill DL. Reference equations for the six-minute walk in healthy adults. Am J Respir Crit Care Med 1998;158:1384-7.

12. Stam H, Binkhorst R. Muscle strength impairment and disability in Guillain-Barre patients: a pilot study. I Rehabilitation Science 1989;2:108-10.

13. Lankhorst G], Van de Stadt RJ, Van der Korst JK. The relationships of functional capacity, pain, and isometric and isokinetic torque in osteoarthrosis of the knee. Scand J Rehabil Med 1985;17:167-72.

14. Rantanen T, Guralnik JM, Izmirlian G, Williamson JD, Simonsick EM, Ferrucci L, et al. Association of muscle strength with maximum walking speed in disabled older women. Am J Phys Med Rehabil 1998;77:299-305.

15. Tyson SF, Thornton HA. The effect of a hinged ankle foot orthosis on hemiplegic gait:objective measures and users' opinions. Clinical Rehabilitation 2001;15:53-58.

16. Beckerman $H$, Becher J, Lankhorst GJ, Verbeek AL. Walking ability of stroke patients: efficacy of tibial nerve blocking and a polypropylene ankle-foot orthosis. Arch Phys Med Rehabil 1996;77:1144-51.

17. Lehmann JF, Condon SM, de Lateur BJ, Price R. Gait abnormalities in peroneal nerve paralysis and their corrections by orthoses: a biomechanical study. Arch Phys Med Rehabil 1986;67:380-6.

18. Perry J. Kinesiology of lower extremity bracing. Clin Orthop 1974;0(102):18-31.

19. Andrews AW, Bohannon RW. Distribution of muscle strength impairments following stroke. Clin Rehabil 2000;14:79-87.

20. Prigatano GP, Wong JL. Speed of finger tapping and goal attainment after unilateral cerebral vascular accident. Arch Phys Med Rehabil 1997;78:847-52. 
21. Haggard P, Cockburn I, Cock I, Fordham C, Wade D. Interference between gait and cognitive tasks in a rehabilitating neurological population. I Neurol Neurosurg Psychiatry 2000;69:479-86.

22. Ruchinskas RA, Singer HK, Repetz NK. Cognitive status and ambulation in geriatric rehabilitation: walking without thinking? Arch Phys Med Rehabil 2000;81:1224-8.

23. Geurts AC, Mulder TW, Nienhuis B, Rijken RA. Dual-task assessment of reorganization of postural control in persons with lower limb amputation. Arch Phys Med Rehabil 1991;72:1059-64. 
Chapter 7 
Chapter 8

Summary 
Chapter 8 
In case of a foot drop due to a peripheral nerve lesion or radiculopathy, the use of an ankle-foot orthosis (=AFO) is often considered. The AFO corrects the foot drop during swing phase and helps to control foot placing after heel strike. However, a possible negative side effect of AFO use might be a further decrease in strength of the paretic dorsiflexors due to disuse. Especially in those patients with a chance of nerve regeneration and subsequent strength recovery, this could be harmful. Chapter 1 discusses the aim of this thesis, i.e. to determine the effects of six weeks of AFO use on (1) the activity of the paretic muscles during walking, (2) restoration of strength, and (3) walking performances in patients with a paresis of the ankle dorsiflexors existing between six weeks and one year.

Various approaches were used to answer these questions. Muscle activity of five lower leg muscles was measured by surface EMG registration while the subject walked on a level treadmill. Isometric ankle dorsiflexion strength was determined on a dynamometer with the ankle joint in $0^{\circ}$ and $30^{\circ}$ plantar flexion. Finally, walking ability was assessed using 3 walking tests: the 10 metre walking test, the 10 metre walking test with three steps and a six-minute walking test with a cognitive task. The SIP68 mobility scale and a questionnaire concerning the subjective effect of AFO use on different walking tasks were finally added.

In chapter 2, a short overview of the aetiology of a drop foot, the clinical symptoms, and the surgical and paramedical interventions is given. Peroneal nerve lesions at the fibular head are mainly caused by compression of the nerve, due to prolonged bed rest, operations, sitting with crossed legs, and, less frequently, by trauma. An L5 radiculopathy may also result in a drop foot and is mostly caused by a protruded lumbar disc. Treatment and prognosis are dependent on the primary cause and duration of the nerve lesion. Treatment can be either conservative or surgical. There is no consensus when surgical intervention is indicated, neither in case of a peripheral lesion nor with a radiculopathy. Only in case of traumatic interruption of the nerve or a distinct mass pressing on the nerve, surgical intervention is commonly advocated. Either way, physiotherapy and/or an orthosis are often (temporarily) prescribed to facilitate walking. The effects of physiotherapeutic training on strength recovery and nerve regeneration is not clear, nor is the effect of AFO use on walking ability and muscle activity.

In chapter 3 the results of immobilisation on strength reduction of the ankle dorsiflexors are described in 15 neurological healthy subjects who had an ankle braced in a plaster cast after an uncomplicated fracture of the lower leg. Immediately after cast removal, isometric ankle dorsiflexion strength in $30^{\circ}$ plantar flexion was $28 \%$ lower compared to the healthy side. We concluded that ankle dorsiflexors are susceptible to immobilisation. Thus, a negative effect of partial immobilisation during AFO use could be possible as well. Reproducibility of the strength measurements in healthy adults was described and reference strength values were reported. 
Chapter 4 describes the influence of AFO use on muscle activity, as measured by surface EMG. EMG activity was recorded to study both quantitative and qualitative changes during the step cycle. The reproducibility of the EMG measurements in healthy adults resulted in a correlation coefficient, reflecting within-subject signal reproducibility, varying between 0.68 and 0.96 (mean 0.86). The immediate change in EMG pattern of the tibialis anterior muscle (TA) induced by AFO use was compared between 29 patients with a dorsiflexor paresis and 14 healthy persons. In both groups, activity of the TA decreased significantly when using an AFO. In healthy persons a decrease of $20 \%$ was seen during the first $10 \%$ of the step cycle. In patients with a paresis the decrease in EMG activity was $7 \%$. However, this decrease was measured over the whole step cycle. Next, the patients were randomly assigned to two groups, with and without daily AFO use. Overall EMG activity did not change during six weeks follow up. Differences between walking with and without orthosis did not change during follow-up in the AFO group in any of the muscles recorded. There was no indication that a gradual decrease in muscle activity due to central adaptation took place.

In chapter 5 the influence of AFO use on strength restoration is studied by comparing the recuperation of the recent paresis between twenty-nine patients alternately assigned to a group using an AFO or a control group during six weeks. No significant difference in duration of the paresis and in torque at entering the study (T0) was present between the two groups. Isometric torque production of ankle dorsiflexors was measured and expressed as ratio of the paretic and healthy side, in two measurement sessions, over a period of six weeks (TO- T6) with the ankle in $0^{\circ}$ and $30^{\circ}$ plantar flexion. Only in $30^{\circ}$ plantar flexion, both groups showed a significant improvement of strength between T0 and T6; the non-AFO group $17 \%(S D=15)$, the AFO-group $9 \%(S D=12)$. There was no significant difference between the two groups (in $30^{\circ}$ plantar flexion). In the AFO-group no significant shift in strength ratio between $0^{\circ}$ and $30^{\circ}$ occurred. It was concluded that the use of an orthosis did not influence restoration of strength in these patients.

Because the relation between an impairment and the subsequent disability is a main feature in rehabilitation medicine, the relation between the degree of paresis and the performance on several walking tests was studied in chapter 6 . The following tests were used: 10 metre walking test (with and without three stairs), a complex walking task (six minute walk with cognitive loading) and a subjective evaluation (SIP68 mobility scale and questionnaire). When relating torque values to walking performances, the highest correlation was found between strength and the "10 metre" and "10 metre with stairs" test $(r=-0.51$, i.e. an inverse relationship). No threshold in the amount of strength loss was found below which walking ability sharply decreased. All walking tests were performed with and without AFO in random order. No significant improvement could be demonstrated from AFO use on the 10 metre tests. Improvement on the six minutes test was significant at $p=0.06$, the questionnaire revealed a positive 
opinion on AFO use related to overall walking function and effort.

Finally, in chapter 7 an overview is presented of the various studies of this thesis, and some additional findings are discussed. The general answer to our main question, i.e. does AFO use counteract muscle activity and strength restoration in patients with a recent foot drop, is: "No, it does not". Our data indicate that it is safe to use an AFO when necessary. Subjectively most AFO users reported an improvement on walking performance and experienced less physical effort. However, we could not demonstrate a significant positive effect of AFO use on the walking tests used.

The present study also provided some additional findings, the first of which were the qualitative and quantitative differences in muscle reaction on AFO use between paretic muscles compared to healthy muscles. Although within-subject reproducibility of strength and EMC measurements in the patient group were similar to the healthy subjects, large inter-individual differences in the patient population existed in contrast to the healthy subject population. Also, especially the EMG measurements, reflected significant qualitative differences between healthy and paretic muscle patterns during a step cycle. These observations underline that results obtained from a healthy population can not be extrapolated to patients.

Second, we concluded that the estimation of severity of the paresis during clinical examination, which is often done by using the healthy side as a reference, can lead to an underestimation of the paresis. We found strength values of the healthy leg in the patient group with the unilateral paresis to be lower as compared to the reference group. On the contrary in subjects with an ankle fracture (discussed in chapter 3), strength of the healthy leg was similar to that in the reference population. Because the same instrument and protocol was used, and patients with a polyneuropathy were excluded from this study, this suggested a general decrease of strength in the healthy leg of the patient group which ranged from $25-50 \%$. Obviously, this phenomenon will interfere with the estimation of the severity of paresis. Whether an explanation must be sought in a global reduction of physical activities, the type of treatment given, patients age or in a reduction of central nervous drive is not clear. Also, to what extent and how quick contralateral reduction of strength and skill is seen remains unclear and is open to further investigation.

Third, we now question the use of the walking tests as a means of evaluating the effect of an AFO. The use of walking tests and questionnaires in our study did not provide information to help deciding whether or not a patient profits from AFO use. The subjective evaluation was often positive and patients reported for instance less fear, more stability and les fatigue. The walking tests probably were not sensitive enough for these items.

Finally, we discussed the relation between the impairment (strength loss) and disability (walking problems). We concluded that the effect of an orthosis on the patient's ability to walk is not predominantly related to the severity of the 
paresis, but seems mainly dependent on the compensation mechanisms the patient is able to use. Future research, therefore, should be directed to understanding the different compensation mechanisms and methods necessary to optimise relearning of motor processes and the use of these compensation mechanisms in neurological impaired persons. 
Appendix 


\section{Dankwoord}

De afgelopen jaren was er één gedachte die mij moed gaf bij het herschrijven van de zoveelste versie van één van de hoofdstukken van dit proefschrift, namelijk het idee dat het schrijven van het dankwoord in ieder geval simpel zou zijn. Dit bleek mijn zoveelste misvatting. $U$ leest nu de $18 \mathrm{e}$ versie.

Dit komt niet omdat niet duidelijk is wie hier in behoort te staan, maar wel omdat het moeizaam blijkt dit enigszins leesbaar en boeiend te beschrijven. Uiteindelijk is dit waarschijnlijk het best gelezen stuk uit mijn proefschrift. Een opsomming is natuurlijk simpel, alfabetisch is zelfs in de mode en biedt iedereen een snel overzicht. Zo gemakkelijk wil ik het echter niet maken. Ik heb regelmatig zitten zwoegen de afgelopen jaren en wil dit gevoel nu ook graag een beetje delen. Daarom krijgt u van mij de omschrijving, aan $u$ om de juiste persoon eraan te koppelen. Het gevoel dat $u$ heeft als $u$ alles kloppend denkt te hebben en bij de laatste ontdekt dat het tóch verkeerd zit, brengt $u$ dicht bij een authentieke onderzoekservaring. Hebt $u$ hier plezier in, en ervaart $u$ dit als een uitdaging, dan schuilt er een onderzoeker in u. Succes.

1. Hij staat op eenzame hoogte in mijn dankwoord. Gedurende het gehele traject van mijn onderzoek, van de organisatie tot de financiering, van de technische tot de analytische problemen, van de diepe depressies tot de momenten van voldoening, was hij telkens betrokken. Hij was de eerste die zich daadwerkelijk verantwoordelijk voelde om met mij te zoeken naar een goede vraagstelling en onderzoeksopzet. Ik heb veel waardering gekregen voor zijn betrokkenheid en gedrevenheid bij het opzetten en begeleiden van eigen onderzoek, dat van zijn promovendi en studenten. Veel dank en ik ga met plezier verder met onze samenwerking.

2. Ook iemand die me aardig geholpen heeft de moed erin te houden. Hoewel ik zijn liefde voor de standaarddeviatie niet ten volle kan delen, heb ik er in ieder geval beter mee leren werken. Zijn scherpe commentaren op mijn stukken, de goede suggesties en het motto; 'niet chronologisch maar logisch rapporteren' zijn erg waardevol geweest. Het langlopend vergelijkend onderzoek naar de verrichtingen van onze kinderen zullen we voorlopig maar continueren. Ook hem hoop ik nog vaak tegen te komen.

3. Mijn dank geldt allereerst het feit dat hij zich over mijn onderzoek ontfermde. Daarnaast hebben de zorgvuldige en nauwgezette commentaren op mijn epistels zeker bijgedragen tot een verbetering van het uiteindelijke proefschrift en een kritischere blik op mijn eigen schrijfsels. 
$4 \& 5$. Deze dames zijn de afgelopen jaren een zeer goede alternatieve begeleidingscommissie gebleken. Uitermate geschikt om steun bij te zoeken tijdens de periodes van frustratie en computer-ellende. Ook de herkenbaarheid bij elkaar van dezelfde valkuilen en doelstellingen gaven deze burger moed. De één wens ik heel veel succes bij de afronding van haar proefschrift én opleiding en ik verwacht dat we nog veel van haar zullen horen. Van de andere dame heb ik met bewondering en enige afgunst de afgelopen jaren haar verrichtingen op onderzoeksgebied gade geslagen. Dank voor het oneindig geduld om mij iets bij te brengen van statistiek en Matlab (píep, error...). Ik hoop haar nog veel te zien en met haar samen te werken. Er wacht hen nu nog één belangrijke taak, mij heelhuids door de promotie loodsen!

$6 \& 7$. Gedurende de metingen heb $i k$, in verschillende fases van het onderzoek ook prettig kunnen samenwerken met twee studentes, die met veel inzet en enthousiasme een deel van de studie op zich hebben genomen en zeer adequaat uitgevoerd. De samenwerking met deze dames was zeer plezierig, en het feit dat zij nu allebei geneeskunde studeren, opent perspectieven voor verdere samenwerking in de toekomst. Veel succes.

8. Hij heeft tijdens zijn opleiding tot revalidatie-arts een actieve en constructieve bijdrage geleverd aan de loopmetingen. Het deed me plezier dat ondanks de frisse tegenzin waarmee hij aan het verplichte onderzoeksdeel binnen zijn opleiding begon, hij er geleidelijk aan zelfs plezier in begon te krijgen (toch?). Dit resulteerde uiteindelijk in een duidelijk eigen inbreng met een presentatie en gezamenlijk artikel ter afronding. Ik wens hem dan ook veel succes en plezier in zijn verdere carrière in Brabant.

Uiteraard had dit hele onderzoek niet plaats kunnen vinden zonder de inzet en medewerking van verwijzers en patiënten. Met name de afdeling Neurologie in Heerlen en een aantal collegae van de Revalidatie in Heerlen, 9 \& 10 \&11, en vanuit Roermond, 12, wil ik van harte bedanken voor hun actieve bijdrage bij het zoeken naar geschikte deelnemers voor deze studie en de interesse in de (deel)resultaten bij hun patiënten. De gegarandeerde anonimiteit voor de proefpersonen en patiënten verhindert dat ik hen hier expliciet noem, maar het mag duidelijk zijn dat hun medewerking en trouw gedurende de follow-up periode bepalend zijn geweest voor de uiteindelijke resultaten.

De orthopedische schoenmakerij in Hoensbroeck, 13, wil ik bedanken voor hun meedenken en meewerken bij het ontwikkelen van een stevige en betrouwbare sensor in de meetschoenen, en de instrumentmakerij, 14, voor het ter beschikking stellen van de EVO's. De SRL en het iRv, dank voor de kans om deze studie op te zetten en tot een goed einde te brengen, en dan met name mijn opleider, 15 , voor het geven van de cruciale duw in deze richting. 


\section{De kandidaten}
A. Pam de Vos
B. Firma Welzorg
C. Huub Vonken
D. Wim Wetzelaer
E. Yvonne Janssen-Potten
F. Jordie van Tuijl
H. Henk Seelen
I. Robert Muhlig
J. Kees Pons
K. Rob Riksen
L. Dia Pernot
M. Firma Hanssen
N. Frank Spaans
O. Jeanine Verbunt
P. Maarten Drost

Ter afronding wil ik graag van de gelegenheid gebruik maken om een aantal mensen te bedanken die zich absoluut niet met dit proefschrift hebben bemoeid en het daardoor allemaal hielpen te relativeren en uiteindelijk te realiseren. Pap en mam, bedankt voor de oppasdagen en ingevroren lekkerheden als ik weer eens zonodig weg moest. Mia, veel dank voor je altijd aanwezig zijn en inspringen op momenten dat ik je weer eens nodig had, het heeft me veel kopzorgen bespaard. Jos, Anouska, en vooral Jeske, Marijne en Ruben, bedankt voor alle afleiding, ga vooral zo door. Gert Jan, bedankt voor je gedoogpolitiek van mijn aanvallen van chagrijn en moedeloosheid, en je ongefundeerd vertrouwen in de goede afloop. Ook mijn bewondering voor je geduld als je me weer eens uit de digitale modder moest slepen terwijl ik stampvoetend mijn laptop uit het raam wilde knikkeren. Hoewel ik je niet kan beloven in de toekomst voor minder onrust te zorgen, zal ik mijn best doen.

\section{De antwoorden}

\begin{tabular}{|c|c|c|c|}
\hline & & $a$ & $=$ \\
\hline ] & $=S I$ & \rfloor & $=$ \\
\hline g & $=t L$ & $\forall$ & $=$ \\
\hline$W$ & $=\varepsilon L$ & $\exists$ & $=$ \\
\hline 7 & $=Z l$ & 0 & $=$ \\
\hline 0 & $=L L$ & $\mathrm{~N}$ & $=$ \\
\hline$y$ & $=0 \mathrm{~L}$ & d & $=$ \\
\hline & $=6$ & $\mathrm{H}$ & $=$ \\
\hline
\end{tabular}




\section{About the author}

Marion Geboers was born in Tilburg at December the 11th 1965. She graduated from the Cobbenhagen College in Tilburg (WWO) in 1984 and started her medical study at the University Maastricht. In November 1990 she graduated as a medical doctor. After a short research period at the Institute for Rehabilitation Research (iRv) in Hoensbroek, she started her specialization in rehabilitation medicine in 1991 in Limburg. After completing this study in March 1995 she started working in the St Maartens Hospital in Venlo and in the Laurentius Hospital in Roermond. She combined her clinical work with research work for this thesis at the iRv. From 1996 until 2000 she also was chairman of the National Educational Board of the VRA (the Organisation of Rehabilitation Specialists) and a member of the Concilium of the VRA. Since March 2000 she is working at the rehabilitation department of the Atrium medical center in Heerlen.

She is married to Gert Jan Mevius and despite everything written above, her greatest job until now was giving birth to their daughter Marijne in 1997 and their son Ruben in 1999. 


\section{Vragenlijst 1}

\section{SIP 68 Mobility Scale}

Bij de volgende vragen kruist $u$ alleen die uitspraken aan, waarvan u zeker weet dat ze op uw huidige situatie van toepassing zijn en tevens samenhangen met uw_gezondheid.

1. ....... Ik loop trappen langzamer op en af.

Bv. met één trede tegelijk, of ik sta vaak stil.

2. ....... Ik loop kleinere afstanden of sta vaak stil om te rusten.

3. …... Ik loop langzamer.

4. ....... Traplopen doe ik alleen met hulpmiddelen.

Bv. de leuning, een stok of krukken.

5. ....... Ik loop zonder hulp, maar met moeite.

Bv. ik loop mank, waggel, strompel, heb een stijf been.

6. ....... Ik kniel, hurk of buk alleen maar wanneer ik me aan iets vasthoud.

7. ....... Ik loop geen heuvels op en af.

8. ....... Ik kom alleen in en uit bed of stoel, wanneer ik me aan iets vast houd, of door gebruik te maken van een stok of driepoot.

9. $\quad$....... Ik sta maar korte tijd achtereen.

10. ....... Ik kleed me wel zelf aan, maar het gaat erg langzaam.

11. ....... Ik heb moeite met dingen waarbij ik mijn handen moet gebruiken. Bv. de kraan open- en dicht draaien, omgaan met keukengerei, naaien, timmerwerk.

12. ....... Ik kan mijn handen of vingers beperkt of moeilijk bewegen.

Bedankt voor uw medewerking! 


\section{Vragenlijst 2}

\section{Gebruik enkel-voet orthese (EVO)}

Hieronder volgen 17 vragen over uw enkel-voet orthese (=evo). Onder iedere vraag staat een aantal mogelijk antwoorden. $U$ kunt met een kruisje aangeven waarmee uw mening zoveel mogelijk overeenkomt.

1. Ik gebruik de evo binnenshuis:

$\square$ nooit

$\square$ zelden

$\square$ soms

$\square$ vaak

$\square$ altijd

2. Ik gebruik de evo buitenshuis:
$\square$ nooit
$\square$ zelden
口 soms
a vaak
$\square$ altijd

3. Ik gebruik de evo tijdens het werken:
$\square$ nooit
$\square$ zelden
$\square$ soms
$\square$ vaak
$\square$ altijd
$\square$ niet van toepassing

4. Ik gebruik de evo tijdens het sporten:

$\square$ nooit

$\square$ zelden

$\square$ soms

vaak

$\square$ altijd

niet van toepassing

5. Ik gebruik de evo gemiddeld

$$
\text { ........ uur per dag. }
$$

6. Over het geheel genomen ben

ik met de evo:

$\square$ zeer tevreden

$\square$ tevreden

$\square$ ontevreden

$\square$ zeer ontevreden
7. Lopen met een evo gaat:
$\square$ zeer goed
a goed
$\square$ slecht
$\square$ zeer slecht

8. Lopen zonder evo gaat:
$\square$ zeer goed
$\square$ goed
$\square$ slecht
zeer slecht

9. Lopen met een evo is:
$\square$ zeer licht
$\square$ licht
$\square$ vermoeiend
$\square$ zeer vermoeiend

10. Lopen zonder een evo is:

$\square$ zeer licht

$\square$ licht

$\square$ vermoeiend

$\square$ zeer vermoeiend

11. Mijn looptempo met een evo is:
$\square$ zeer hoog
$\square$ hoog
$\square$ normaal
$\square$ laag
$\square$ zeer laag

12. Mijn looptempo zonder een evo is:
$\square$ zeer hoog
a hoog
$\square$ normaal
D laag
$\square$ zeer laag 
13. Traplopen met een evo is:

$\square$ zeer makkelijk

makkelijk

a normaal

$\square$ moeilijk

- zeer moeilijk

14. Traplopen zonder een evo is:

$\square$ zeer makkelijk

- makkelijk

a normaal

a moeilijk

zeer moeilijk

15. Hurken en opstaan met een evo is:

口 zeer makkelijk

$\square$ makkelijk

normaal

a moeilijk

$\square$ zeer moeilijk

16. Hurken en opstaan zonder een evo is:

zeer makkelijk

a makkelijk

$\square$ normaal

a moeilijk

$\square$ zeer moeilijk

17. Ik vind het dragen van een evo:

a zeer prettig

$\square$ prettig

$\square$ neutraal

$\square$ vervelend

$\square$ zeer vervelend 
Appendix 